\title{
CHARACTERIZATION AND REMOVAL EFFICIENCY COMPARISON OF BIORETENTION SOIL MEDIA MIXTURES
}

\author{
A Thesis \\ presented to \\ the Faculty of California Polytechnic State University, \\ San Luis Obispo
}

\author{
In Partial Fulfillment \\ of the Requirements for the Degree \\ Master of Science in Civil \& Environmental Engineering
}

by

Nathan Hanson

June 2018 
(C) 2018

Nathan Hanson

ALL RIGHTS RESERVED 
TITLE: Characterization and Removal Efficiency Comparison of Bioretention Soil Media Mixtures

AUTHOR: Nathan Hanson

DATE SUBMITTED: June 2018

COMMITTEE CHAIR: Rebekah Oulton, Ph.D. Assistant Professor of Civil and Environmental Engineering, P.E.

COMMITTEE MEMBER: Yarrow Nelson, Ph. D. Professor of Civil and Environmental Engineering, P.E.

COMMITTEE MEMBER: Robb Moss, Ph. D. Professor of Civil Engineering, P.E., F.ASCE 


\begin{abstract}
Characterization and Removal Efficiency Comparison of Bioretention Soil Media Mixtures Nathan Hanson
\end{abstract}

Bioretention cells have become a commonly used green infrastructure technique to help infiltrate and remove contaminants from stormwater runoff. Bioretention cells are constructed from a layered or heterogeneous soil mixture designed to optimize their ability to infiltrate influent stormwater and remove contaminants carried by the water as it filters through the soil media. The soil mixture, composition, and planting vary depending the local regulatory agencies. As urbanization occurs across the United States, more natural land is converted from pervious surfaces, such as grasslands and forests, to impervious surfaces such as asphalt and concrete, to help reduce the impact of the runoff generated by this increased flow bioretention cells are an often-used method to treat stormwater. These impervious surfaces do not allow rainfall to infiltrate, and the water runs off into receiving water bodies such as rivers and streams as a non-point source pollutant. To help reduce pollutant loadings into receiving water bodies, Low Impact Development (LID) techniques were developed to reduce stormwater volume, peak flow, and contaminant loading rates. The bioretention cell is one of the most popular LID techniques and is comprised of a soil media that is either a layered or homogenous media, which is built following a regional agency's standard. The performance of bioretention soil media is highly variable depending on the amount of each soil constituent present in the media. 
This study compares five different soil mixtures from various agencies' specifications to determine which media composition is most effective at removing total suspended solids (TSS) and nitrates, two of the most prevalent contaminates carried by stormwater. This study also compares mixtures' hydraulic conductivity which determines the volume of water that the media can infiltrate and "treat". To perform these tests, six columns of soil media were constructed with media depths of $91.5 \mathrm{~cm}$ (36 inches). Columns were dosed with either tap water (Phase I) or a synthetic stormwater blend (Phase II) to determine the amount of TSS and nitrate exported by each mixture. The soil mixture in each column was characterized to understand how soil characteristics effect the performance of the various media mixtures.

The bioretention soil media columns were all shown to be effective at removing influent TSS with an average removal rate of over $88 \%$ across all the columns, ranging from $99.9 \%$ removal to $73.6 \%$ removal. Most bioretention soil mixtures used in the test were shown to be ineffective at removing influent nitrates, with breakthrough of nitrate occurring after the first two pore volumes. Interestingly, the media with higher organic content were more effective at removing nitrates, with removal rates as high as $59.9 \%$ compared to the media with lower organic content. Hydraulic conductivity was also highly variable across the various soil media mixtures depending on the percentage of sand and fine media particles present in the media. Hydraulic conductivity ranged from a high value of $42 \mathrm{~cm} / \mathrm{hr}$ to a low of $8.3 \mathrm{~cm} / \mathrm{hr}$. By comparing these results, a more effective bioretention soil media mixture can become agency standard and allow bioretention cells to have more consistent and better performance. 


\section{ACKNOWLEDGMENTS}

I'd like to thank my advisor, Dr. Rebekah Oulton, for working with me throughout the year and beyond as I began work and continued to write my thesis. You encouraged me to develop my passion for stormwater into a thesis and beyond as an advisor of Cal Poly Rainworks. Your hours of guidance and work, as well as your belief in my abilities was deeply impactful to me and I cannot thank you enough. I would also like to offer my sincerest thanks to Nephi Derbidge who worked tirelessly with me to help design the experimental apparatus and guide me through the soil characterization work. Without Nephi's help this project would not have been possible. Thank you to Dr. Robb Moss, Dr. Yarrow Nelson, and Dr. Misgana Muleta for being so encouraging in my pursuits in the field of stormwater, your support and enthusiasm is something I am immensely grateful for.

Lastly, I'd like to thank my family, especially my mother and father Caroline Hanson and Peter Hanson, for being the best emergency lab assistants and proofreaders that I could ask for. I would also like to thank my peers for their support, encouragement, and help throughout the year. I am thankful and honored to have worked with such an amazing set of individuals as I worked with through my graduate education. 


\section{TABLE OF CONTENTS}

Page

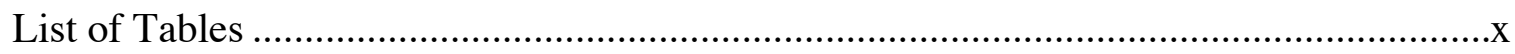

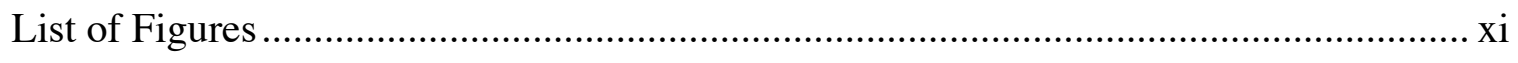

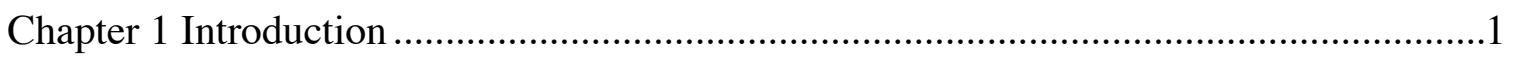

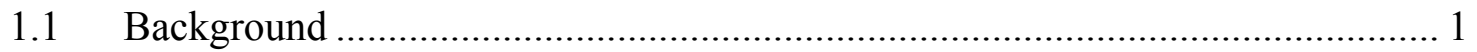

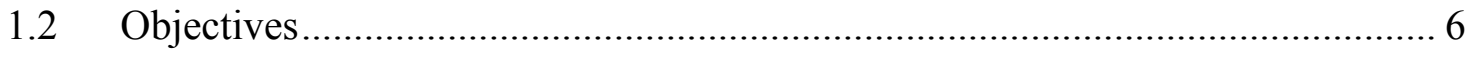

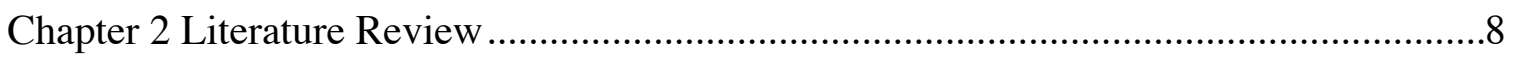

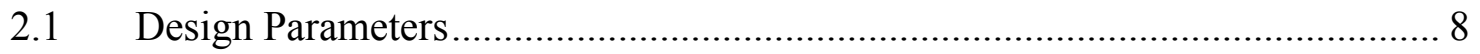

2.1.1 Bioretention Soil Media Selection ......................................................... 8

2.1.2 Effects of Soil and Sand Ratio in Bioretention Soil Media ......................... 9

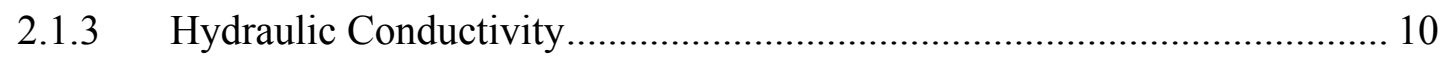

2.2 Contaminant Removal Efficiencies.............................................................. 11

2.2.1 Total Suspended Solids Removal ............................................................. 12

2.2.2 Nitrogen Species Removal.................................................................. 13

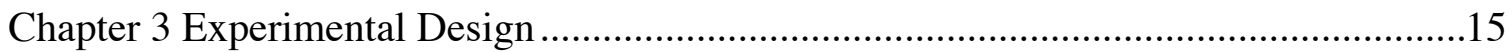

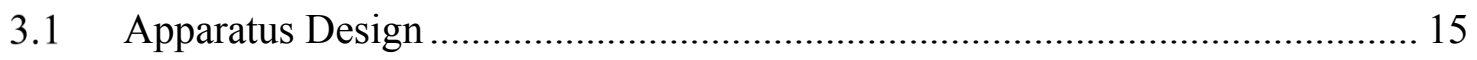

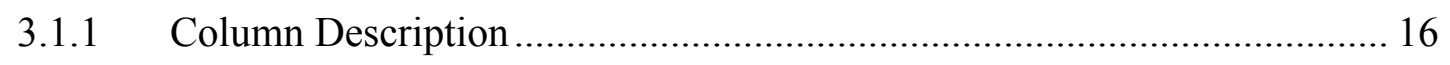

3.1.2 Materials Used in Construction .............................................................. 19

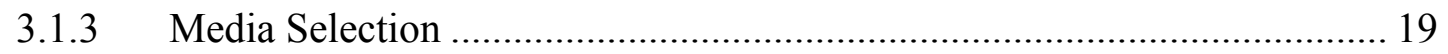

3.1.4 Experimental Bioretention Soil Media ............................................... 23

3.2 Experimental Procedure and Analysis Methods ............................................ 24

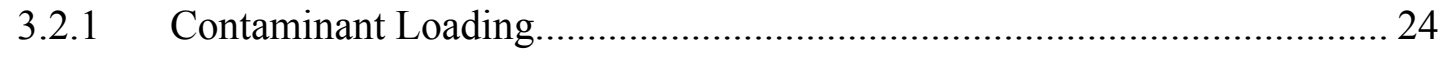

3.2.2 Effluent Volume Measurements from the Columns ................................ 25

3.2.3 Experimental Procedure for Clean Bed Testing ....................................... 26

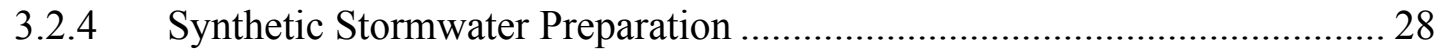

3.2.5 Experimental Procedure for TSS and Nitrate Testing ............................. 29

3.2.6 Hydraulic Conductivity Measurements ................................................ 30

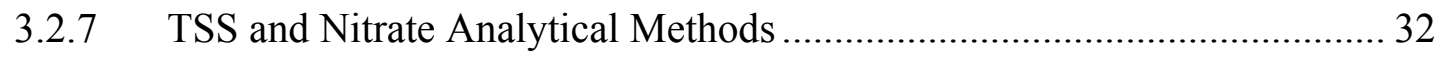




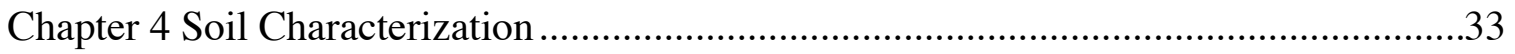

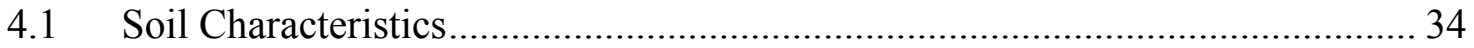

4.1.1 Specific Gravity of the Media Constituents............................................... 35

4.1.2 Particle Size Distribution ......................................................................... 39

4.1.3 Pore Volume Determination ..................................................................... 44

4.1.4 Organic Matter in Bioretention Soil Mixtures ............................................. 45

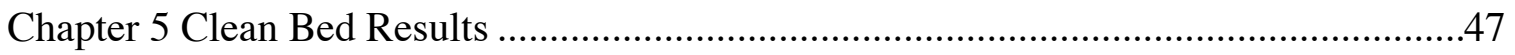

5.1 Total Suspended Solids Leachate during Clean Bed Testing ............................ 47

5.2 Nitrate Leachate during Clean Bed Testing .................................................. 51

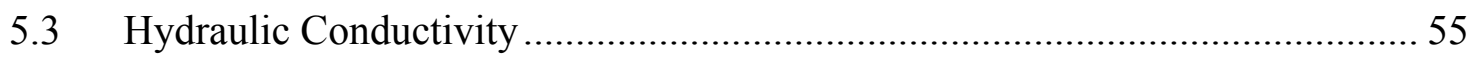

Chapter 6 Synthetic Stormwater Results and Discussion ..............................................58

6.1 Total Suspended Solids Removal................................................................. 58

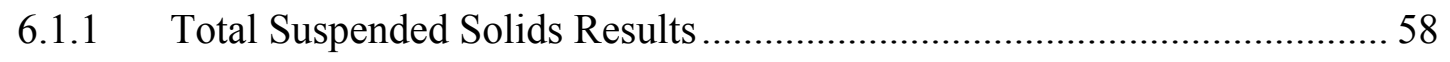

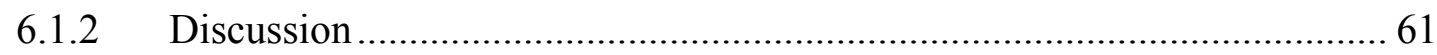

6.2 Change in Hydraulic Conductivity Due to Clogging ………............................ 63

6.2.1 Hydraulic Conductivity Results During TSS Testing................................... 64

6.2.2 Discussion of Hydraulic Conductivity Results ........................................... 67

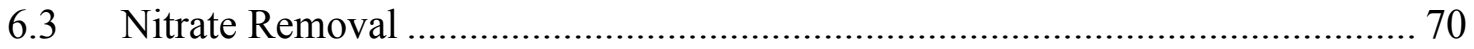

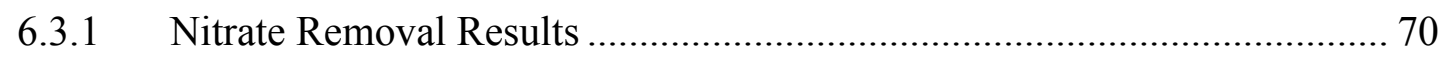

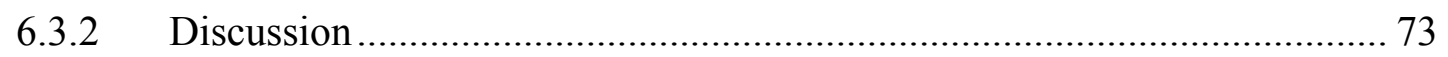

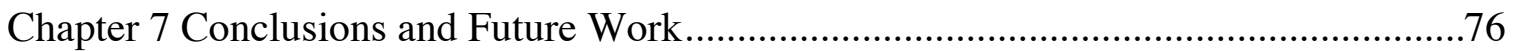

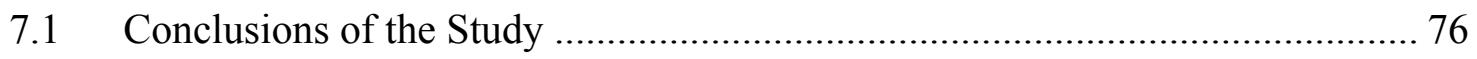

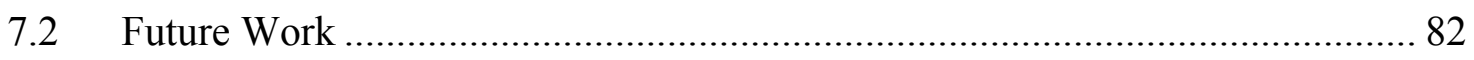

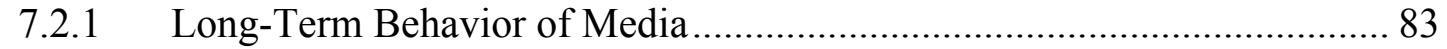

7.2.2 First Flush Analysis ............................................................................. 83

7.2.3 Optimization for Further Study of TSS and Nitrate Removal Behavior .... 84

7.2.4 Testing of Other Contaminants of Concern ................................................ 84

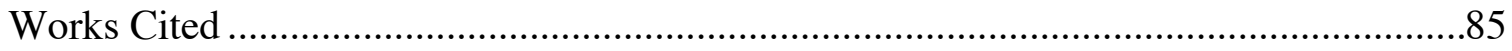

Appendices

Appendix A: Specific Gravity Testing Results ……………................................... 90 
Appendix B: Mechanical Sieve Analysis Results …………...................................... 96

Appendix C: Influent Total Suspended Solids Results ............................................... 103

Appendix D: Hydraulic Conductivity Results ......................................................... 106

Appendix E: Influent Nitrate Testing Results ........................................................... 107

Appendix F: Total Suspended Solids Results For Clean Bed and Nitrate

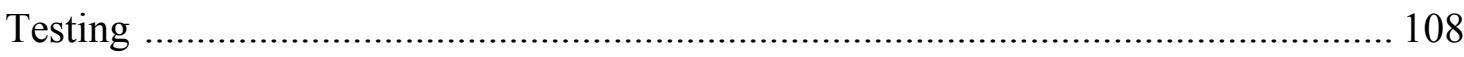




\section{LIST OF TABLES}

Page

Table 1: Media Compositions of Selected Stormwater Agencies 21

Table 2: Percent Passing Requirements for Sand Compared to AirVol Block

Concrete Sand (Control) 23

Table 3: Average Influent Concentrations of Stormwater Contamination ....................... 25

Table 4: Pore Volumes of the Bioretention Media Soil Media by Column Number ....... 26

Table 5: Average Measured Influent Concentrations …………………………............. 29

Table 6: Specific Gravity Absorption of Different Soil Media ........................................... 38

Table 7: Combined Specific Gravity of the Soil Media ……………………………..... 38

Table 8: Specific Gravity of Each Soil Media Column Based on Soil Composition ....... 39

Table 9: Grain Size Distribution for Compost, Top Soil, and Concrete Sand................... 40

Table 10: Synthetic Grain Size Distribution of Bioretention Soil Media .......................... 42

Table 11: Pore Volumes of the Bioretention Media ........................................................... 45

Table 12: Organic Content of Each Soil Constituent........................................................ 46

Table 13: Organic Content of the Bioretention Soil Media Mixtures ................................ 46

Table 14: Average Concentration of TSS Leachate from the Bioretention Soil Media ... 50

Table 15: Average Concentration of Nitrate as Nitrogen Leachate from the

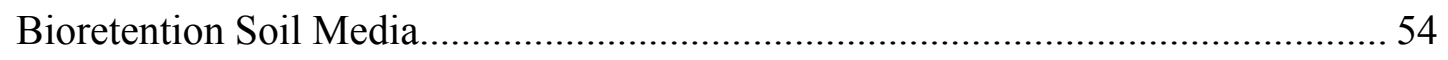

Table 16: Average Concentration of TSS Leachate from the Bioretention Soil Media

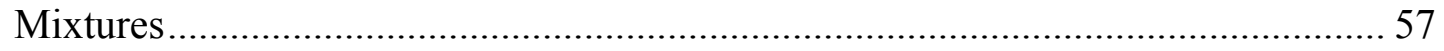

Table 17: Average Effluent Concentration in the Bioretention Soil Media During TSS

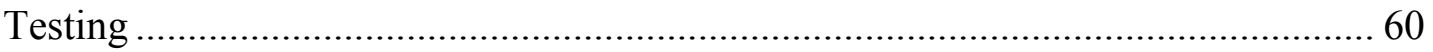

Table 18: Hydraulic Conductivity of the Bioretention Soil Media During TSS

Testing 66

Table 19: Average Nitrate Removal of the Bioretention Soil Media Columns During

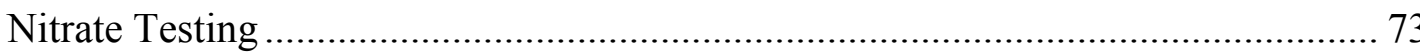

Table 20: Ranking of Bioretention Soil Media Columns and their removal rates and hydraulic Conductivity during TSS and Nitrate Testing ........................................... 80 


\section{LIST OF FIGURES}

Page

Figure 1: Bioretention Cell Rendering showing media layers and the underdrain. 4

Figure 2: Sample Schematic of the Base of each Soil Column and their

drainage system

Figure 3: Bioretention Media Columns seated in the Wooden Rack with Float

Valves and Distribution Pipes. 18

Figure 4: Column compositions and numbering with a Plan View Representation of the Columns...... 34

Figure 5: Top Soil Media After Separation ................................................................... 36

Figure 6: Soil Media in Pycnometers with a Vacuum Pump Applied ............................. 37

Figure 7: Gradation Curve of Compost, Top Soil, and Concrete Sand ........................... 41

Figure 8: Gradation curve of the Bioretention Soil Media ............................................. 43

Figure 9: Clean Bed Effluent Concentrations for Total Suspended Solids in

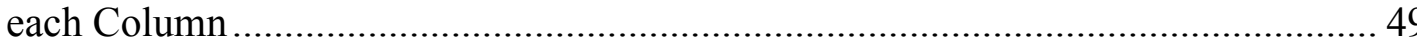

Figure 10: Clean Bed Effluent Concentrations of Nitrate ........................................... 53

Figure 11: TSS Concentration in the Effluent of Various Bioretention Soil Media......... 59

Figure 12: Hydraulic Conductivity of the Bioretention Soil Media During Clean Bed Testing..... 65

Figure 13: Hydraulic Conductivity of the Bioretention Soil Media During TSS

Testing 66

Figure 14: Nitrate as Nitrogen Concentrations of Influent Synthetic Stormwater 72 


\section{Chapter 1 Introduction}

Increasing runoff due to urbanization has two primary effects: firstly, it increases the total volume of stormwater that flows into receiving water bodies, which can cause flooding in urban areas and erosion in those water bodies ${ }^{3}$. Additionally, as stormwater runs off impervious areas, the water can pick up and carry contaminants like solids, oils and greases, nitrates, and heavy metals that can be harmful to receiving rivers, lakes, and streams ${ }^{19}$. This study explores opportunities to reduce rain water runoff and contaminant transfer through appropriate design of Low Impact Development (LID) rain water management practices. In particularly, with the use of the bioretention cells. Bioretention cells are constructed from a layered or heterogeneous soil mixture which is designed to have both a high infiltration rate to reduce stormwater peak flows to receiving water bodies, and high contaminant removal efficiency. The soil media composition of bioretention cells is highly variable depending on the regulatory agency, and can cause significant variation in results. This study aims to determine which media mixtures from five different regulators in California is the most effective at removing contaminants and infiltrating stormwater.

\subsection{Background}

According to the U.S. Environmental Protection Agency's 2007 National Water Quality Assessment, $35 \%$ of U.S. streams are severely impaired, and $75 \%$ of the population lives within 10 miles of an impaired surface water body. The US Clean Water Act (CWA) defines that waterways must be "fishable" and "swimmable" and meet regulatory requirements. Any 
waterway that does not meet these standards is considered impaired, and is regulated by Total Maximum Daily Load (TMDL) which establish a maximum pollutant loadings that can be added to a waterbody on a per-day basis. These TMDLs are based on the specific contaminant that is believed to be the cause of the impairment in the waterbody. Two common contaminants across the US and in California are Total Suspended Solids (TSS) and Nitrate ${ }^{26}$. Both contaminants have TMDLs for many impaired water bodies. A challenge with controlling both TSS and nitrate impairments is that they are often not caused by point source pollution, but are instead caused by non-point source pollution such as contaminated stormwater.

Due to this degradation of U.S. waterways and aquifers, effective storm water management has become a national priority. Improved methods for dealing with storm water have emerged with the introduction of green infrastructure, LID techniques, and green building ordinances. Two of the main contaminants of concern in California are total suspended solids (TSS) and Nitrates. The TSS present in stormwater is caused by soil and other debris from lawns, street depositions, construction sites, and vegetated areas being carried into the traditional stormwater conveyance systems such as pipes and deposited directly into receiving water bodies. Unlike natural settings where the stormwater runoff is significantly slower due to the permeable and rough surfaces it travels over, urban surfaces provide little to no opportunity for stormwater to flow slowly enough to deposit the sediments it carries. The excess sediments carried to receiving water bodies cause turbidity to rise, damaging aquatic habitat and causing degradation of the stream $b^{26}{ }^{26}$. Other contaminants, such as metals and phosphates, can also bind to particles carried by stormwater causing additional habitat damage and/or creating a human health risk. 
Nitrates are also mobilized by stormwater flowing over landscaped or fertilized areas. Since there is rarely a chance for the stormwater to infiltrate through soil or be absorbed by vegetation as the stormwater is conveyed away from the surface, nitrates picked up by the stormwater may flow directly into receiving water bodies. Once in these water bodies, nitrate can cause algae blooms which in turn can cause eutrophication. In addition, excess nitrate can be harmful, or even fatal to human beings especially infants, due to Methemoglobinemia, or Blue Baby Syndrome. This illness is caused by a lack of oxygen being able to be delivered to the body due to hemoglobin binding with nitrates causing a higher than normal concentration of methemoglobin ${ }^{27}$.

One best management practice (BMP) that has been widely adopted to improve stormwater management is the bioretention cell ${ }^{10}$. Bioretention cells operate by filtering stormwater runoff through a soil filter bed, and, depending on the surrounding soil type, through an underdrain or into native underlying soils, as shown in Figure 1. Bioretention cells also offer municipalities the chance to increase their green space and provide an aesthetically pleasing way of passively treating stormwater contamination. For these reasons bioretention cells have become a popular method of treating stormwater contamination across the United States.

It is while the water moves through the soil bed of the bioretention cell that a majority of contaminates are removed physically by filtration or chemically by sorption to the soil surfaces. The infiltration of water into the surrounding soils also provides the added benefit of potentially adding water to local aquifers as the water infiltrates into the deeper surrounding soils. The filtering of stormwater through the bioretention soil media has shown to be effective at removing influent TSS by capturing the soil particles within the bioretention cells' own soil matrix ${ }^{24}$. By infiltrating stormwater carrying nitrates, the 
bioretention soil media can also provide areas for nitrates to sorb onto the bioretention soil media, and since bioretention cells are typically planted with vegetation the nitrates can be utilized and absorbed by the plants ${ }^{16}$. Different mixtures of soil media have shown to be more or less effective at removing various contaminants depending on the blend and quantity of soil types used in the media.

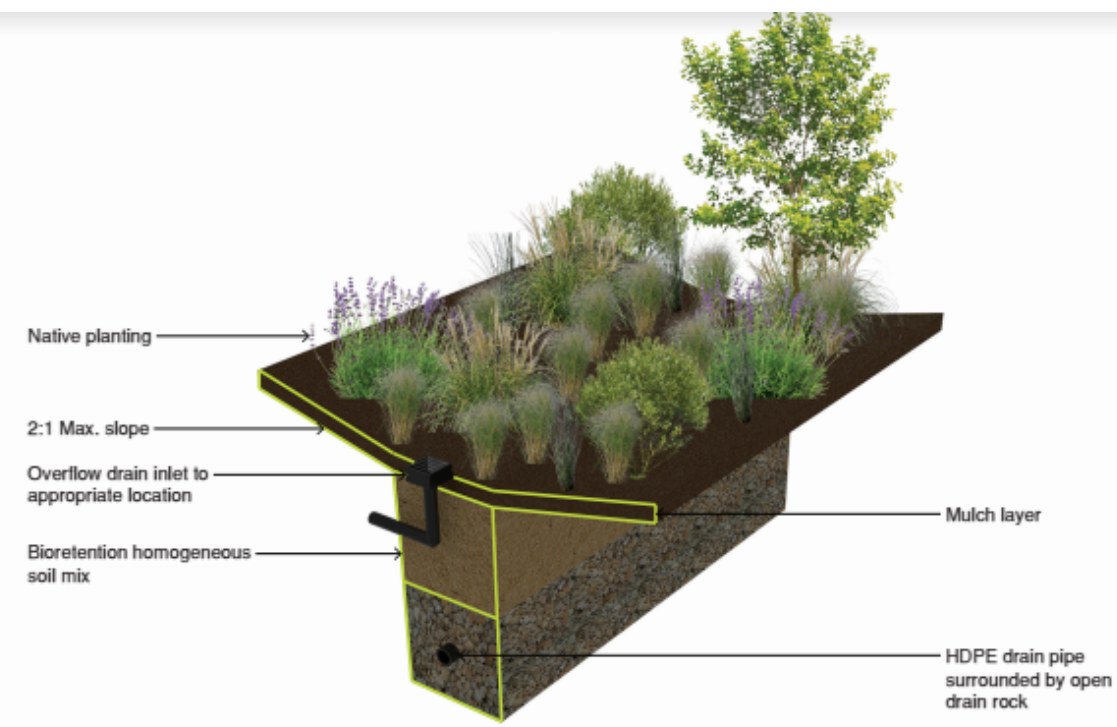

Figure 1: Bioretention Cell Rendering showing media layers and the underdrain

Research pertaining to the effectiveness of bioretention cells in the semi-arid climates of California and the Southwestern United States has been limited. The semi-arid climates of this region experience long dry periods followed by periods of intense rainfall. This weather pattern can cause a high concentration of contaminants to flow into receiving water bodies, called the "first flush" ${ }^{29}$. The potency of this first flush of pollutants may decrease the 
treatment efficiencies of traditional LID techniques. It is therefore especially important for the removal efficiencies and hydraulic conductivities of various bioretention soil mixes utilized in semi-arid climates to be tested in response to these first flush conditions, in terms of both effective rain water infiltration and pollutant removal.

Some initial local work has been done by various municipalities and non-profits such as the City of Santa Barbara or the Central Coast Low Impact Development Initiative ${ }^{28}$. These groups determined which soil mixtures would be most effective at removing contaminants and specified certain characteristics for each. These characteristics include a minimum infiltration rate, standards that the soil used in a mixture must meet, the volume of each soil type needed, planting types, and other recommendations depending on the individual specification. The key component present in all the bioretention soil media mixtures is concrete sand, which forms the bulk of the soil in all the different media types. This is likely due to concrete sand's widespread availability, good hydraulic conductivity ${ }^{12,21}$, and specific gradation characteristics outlined in ASTM Standard C33. The next most commonly used material in bioretention soil media is compost, which is also present in every media recommendation tested in varying quantities. Typically, specifications call for a compost mixture that does not contain a significant portion of fine material as this could cause clogging in the media ${ }^{12}$. However, unlike concrete sand, there is no specific gradation size requirements for compost so its gradation and other characteristics can vary widely. Finally, several mixtures call for the inclusion of top soil. The top soil provides more organic content, like the compost, and is also a widely available material. However, like compost there is no official stringent definition of particle size and composition of top soil, which can cause variation in performance of different bioretention cells using the percentages of each soil 
type. Also, bioretention soil media specifications studied vary significantly in percentage of soil volumes from agency to agency regardless of weather patterns.

\subsection{Objectives}

This study aims to quantify the contaminant removal efficiency and hydraulic conductivity of several bioretention soil mixes (BSMs) used in California and the Southwestern United States under simulated first flush conditions. Specifically, this study will determine if a higher organic content in the bioretention soil improves contaminant removal efficiency for TSS and nitrates and whether the higher organic content leaches nitrogen into the stormwater effluent. Additionally, this study will determine if significant clogging of the BSM occurs after removing total suspended solids from first flush influent rain water, leading to longterm reduction in bioretention cell performance.

The main objectives of this Study include:

1. Which municipal bioretention cells soil mixtures are most effective at removing the total suspended solids and nitrates, this study's two primary contaminants of concern?

2. How does the hydraulic conductivity of the BSM mix vary, and what soil characteristics in the media are responsible for this variance?

3. Do certain BSM mixes clog faster than others when fines carried by first flush storm water are introduced to the system, as indicated by reduction in system hydraulic conductivity? 
To complete these objectives, a testing apparatus had to be designed and developed to allow for controlled testing of these various BSMs under consistent environmental conditions. Testing requirements included creating a system that can operate with a constant head above the media since this is how they are designed to operate when infiltrating stormwater during design storms, and sizing the columns so that results can be applied to full scale bioretention cells. A detailed discussion of design of this apparatus is included in Section 3. 


\section{Chapter 2 Literature Review}

Bioretention cells have been well studied by various means including: column tests, full scale in-situ systems, and mesocosms $\mathrm{s}^{21,2,13,14,15,21,24}$. These studies identify typical removal rates of different contaminants by bioretention cells with various soil mixtures. This section reviews the work done previously in this area and identifies how it will be built on in this study.

\subsection{Design Parameters}

Specifications for bioretention cells typically include specification indicates: the media type and soil layering, soil composition, whether vegetation is present in the media, and the geometry of the bioretention cell (including depth and shape of the bioretention cell). The bioretention cell's hydraulic conductivity and its contaminant removal efficiency are determined by the its soil mixture which as based on specifications and regulations by local, regional, state or federal agencies. Therefore, it is crucial to understand how a change in specification affects the bioretention cell's ability to treat stormwater runoff.

\subsubsection{Bioretention Soil Media Selection}

Bioretention cell media are comprised of a mixture of different soil types, primarily sand and other soil types that contain finer particles. The volume of each soil type used has the greatest effect on the bioretention cell's removal efficiency and its hydraulic conductivity ${ }^{14}$. 
Depending on the agency recommending the bioretention soil media, different standards and ranges are used to define what is an acceptable soil mixture. However, a small variation in media size and heterogeneity can cause significant changes in pollutant removal efficiencies and hydraulic conductivity ${ }^{14}$. Organic matter in bioretention soil mixtures has also been found to act as an additional nitrogen source in the media itself, and it has been identified as a cause of the negative nitrate removal rate in several studies ${ }^{2,8,24}$.

In addition, the way the media is configured can affect media performance. A layered media can have different removal efficiencies compared to a homogenous mixture with equivalent soil quantities ${ }^{12}$. Media configuration can also effect hydraulic conductivity, with layered media typically having regions of low permeability where more fine particles are present. This low permeability layer can have a significant impact on the hydraulic conductivity of the overall system ${ }^{12}$. This is especially true if an area of low permeability is present at the top of the bioretention soil media, where the lower driving water head would decrease the media hydraulic conductivity compared to a media with the same low permeability area at the base.

\subsubsection{Effects of Soil and Sand Ratio in Bioretention Soil Media}

Larger pore sizes, present in sandy soils, have been shown to have a higher hydraulic conductivity compared to smaller particles ${ }^{12}$. However, finer soils have been shown to be more chemically active and effective at removing contaminants from water as it infiltrates through the soil ${ }^{1}$. Balancing these two factors is critical to creating a media that performs well both hydraulically and for contaminant removal. Media with too little chemical reactivity may not effectively remove contaminants from stormwater as it percolates through the media, while media with a high chemical activity but low hydraulic conductivity may 
have a significant portion of the influent stormwater flow bypass the bioretention cell entirely. This situation would both limit the cell's ability to remove contaminants as untreated water would flow directly into the bypass structure, but also the ability of the bioretention cell to attenuate peak flows.

A study by Limouzin et al. (2011) tested various combinations of bioretention media and found that masonry sand and sandy loam performed better at TSS removal over the duration of the study than a concrete sand based medium ${ }^{21}$. They also found that a lower hydraulic conductivity was positively correlated with TSS removal. Interestingly, they found that no organic matter was needed to achieve nitrate and phosphorous removal in their media, with pure masonry sand with no organic matter performing well at removing nutrients. In another study by Hsieh and Davis ${ }^{13}$, 18 different combinations of bioretention media were analyzed for pollutant removal and hydraulic conductivity. They also found that a mixture of sand and sandy loam soils was the best option, and recommended varying sandy loam soils based on vegetation demand and sensitivity ${ }^{13}$. A pure sand media was observed to be most effective or as effective at removing TSS in both studies. However, this may be due to fewer fines washing out of the sand media compared to media with soils added. This result could mean that a sand and soil mixture is equally effective at removing solids, but a portion of the soil fines washes out during a rain event causing a higher TSS concentration in the effluent.

\subsubsection{Hydraulic Conductivity}

A variety of factors affect the hydraulic conductivity of bioretention soil media. As stated above, larger pore sizes in sandy soil have a higher hydraulic conductivity compared to smaller particles ${ }^{12}$. Once the bioretention soil media is in place however, the key factor 
affecting hydraulic conductivity is clogging of the media. Runoff that carries smaller soil particles tend to clog the soil media ${ }^{8,21}$. Overall decreases in hydraulic conductivity of a bioretention soil media over time was shown to be as high as $73 \%$ over the course of 72 weeks ${ }^{18}$. An initial decrease in hydraulic conductivity by more than $50 \%$ on average in bioretention soil mixtures during the first 8-months of operation was also seen in an experiment by Limouzin et al. ${ }^{21}$. However, most of the media recovered a significant portion of its hydraulic conductivity after 11-months of operation, and no column clogged completely. Understanding how quickly systems clog and how best to restore the soil media to its original hydraulic conductivity is crucial if municipalities and stormwater agencies want to keep these systems as effective as possible for as long as possible.

Two common methods used to reduce clogging in bioretention media are with vegetation and mulch. Vegetation has been shown to have mixed results on preventing clogging ${ }^{18}$, with some plant species being very effective at keeping hydraulic conductivity high, while others showed the same decreases in hydraulic conductivity as the media alone. This effect on hydraulic conductivity is likely due to the root characteristics of certain plants - specifically the roots' ability to create marcopores in the soil to help establish preferential flow paths. Conversely, other tests show that vegetation alone was enough to prevent the media from clogging $^{21}$. Mulch, another commonly recommended constituent for the top layer of bioretention soil media, is recommended as another way to prevent bioretention soil media from clogging ${ }^{14}$.

\subsection{Contaminant Removal Efficiencies}

Bioretention cells have resulted in varying percent removal for different pollutants, but typically 
they can effectively remove total suspended solids, chromium, zinc, and lead from effluent ${ }^{8,9}$. Typically, organics and nitrate effluent concentration increase due to leaching of the soils, mulch, and vegetation in the bioretention cells ${ }^{7}$. However, based on the results of several sources $^{9,24}$, some media mixtures have been shown to be effective at removing nitrates from influent stormwater. There seems to be no simple answer to how effective bioretention soil media is at removing nitrates due to biogeochemical complexity of the nitrogen species ${ }^{21}$ and the unique characteristics of every soil blend. Due some testing showing positive nitrate removal, many municipalities allow bioretention cells to be an option to remove nitrates from influent stormwater $^{28}$. If it is true that most bioretention cells leach nitrates from their own organic media components, their use as a treatment option for municipalities could be questionable if they need to decrease nitrate loadings in their receiving water bodies.

\subsubsection{Total Suspended Solids Removal}

Bioretention cells have been shown to be very effective at removing TSS from influent stormwater, with removal rates ranging from $88 \%^{13}$ to over $98 \%{ }^{24}$. Since TSS removal is a physical straining process, the pore size and gradation of the bioretention soil media is what allows for the capture of influent particles. The high removal of TSS is also beneficial for removal of certain contaminants. For example, some contaminants such as lead tend to sorb to soil particles carried by stormwater. Thus TSS removal via filtration also removes these sorbed contaminants ${ }^{13}$.

A majority of the influent TSS filtered out of the influent stormwater in the first $10 \mathrm{~cm}$ of the media ${ }^{19}$. This can cause potential clogging as the top of the media's void space fills with new soil particles. 


\subsubsection{Nitrogen Species Removal}

Depending on the media composition, nitrogen species removal is highly variable in bioretention soil media. In previous studies, nitrates have been shown to leach into effluent at substantially higher concentrations $s^{2,24}$, have little to no change from influent flows ${ }^{2}$, or have a high removal rates of influent nitrogen species ${ }^{9,22}$. Typically, total nitrogen $(\mathrm{TN})$ concentrations decrease as stormwater flows through the bioretention cell media ${ }^{9}$, but removal nitrate is highly dependent on vegetation and percent organics in the soil. As mentioned above, organic matter in bioretention soil mixtures has also been found to act as a nitrogen source in the bioretention soil media in previous studies, causing negative removal rates ${ }^{24}$. However, if a section of the bioretention cell is allowed to remain saturated, denitrification of influent stormwater has been shown to occur with up to $75 \%$ of the nitrogen being removed ${ }^{15}$. To be more effective however, a carbon source in the form of organic matter must be present in the media or removal rates can drop dramatically ${ }^{15}$. It is unclear from these two studies whether including organic content to allow denitrification offsets the potential for nitrate to leach into the effluent from added organic matter.

Vegetation planted within the bioretention cells allows for denitrification to occur in the rhizodeposition zone ${ }^{16,22}$ on the order of 10 to 12 hours. Vegetation can also rapidly draw nitrogen into shoots and stems ${ }^{22}$, but this process is highly variable based on plant species ${ }^{24}$. Without vegetation, immobilization and capture of $\mathrm{NO}_{\mathrm{x}}$ species becomes more difficult, and rapid breakthrough in unplanted systems can occur ${ }^{2}$. However, it is also believed that additional nutrients can originate from planted vegetation and organic material in soil in the bioretention cells themselves ${ }^{11}$. Since the aim of this study is to look at the effectiveness of the various soil 
media, vegetation will not be added to any of the soil columns. This deliberate omission could lead to results that behave differently than in-situ cells using the same media that contain vegetation, but this study does provide a baseline for later studies by which these values can be compared to see if vegetation causes a net export or more capture of nitrate species. 


\section{Chapter 3 Experimental Design}

To analyze the effectiveness of the various bioretention cell (BRC) soil mixtures, a six-column apparatus was constructed to mimic the behavior of a full-scale BRC system in each column. The soil mixture inside each column was based on the specifications provided by five different municipalities in California with the sixth column serving as a sand-only control. Clean bed testing allowed for determination of leaching and gave a baseline hydraulic conductivity for the soil media, while experiments with synthetic stormwater allowed for determination of TSS and nitrate removal, and change in hydraulic conductivity in response to the first flush.

\subsection{Apparatus Design}

The primary goal was to build a system that allowed for laboratory scale flexibility and control, in such a way so its results could be relevant to full scale systems. To make the results mimic a full-scale system as accurately as possible, each column had the same media and ponding depth that a full-scale system would have based on the specification to which each was built. The columns were constructed out of 8-inch diameter pipe to avoid boundary conditions having a significant impact on the flow through the columns. The impermeable column wall also mimicked the poorly draining native soils common in California (USGS). Effluent was collected through an underdrain system that could be present in bioretention cells found in poor hydraulic soil. This underdrain also allowed the effluent from the column to be easily collected and sampled. The water distribution system placed above the columns was designed so a constant ponding depth would be maintained above all the columns and synthetic stormwater would be 
distributed evenly as the columns reached their maximum ponding depth. The saturation of each column could be controlled by sealing the valve at the base of each column's effluent pipe.

\subsubsection{Column Description}

Six columns with various bioretention soil media were constructed. Columns were built using 8-inch (inner diameter) schedule 40 PVC piping to avoid boundary conditions between the bioretention media and columns as much as possible. The total height of the columns used in this experiment were $132 \mathrm{~cm}$ (52 inches) tall and consisted of $91.5 \mathrm{~cm}$ (36 inches) of soil media, 33 $\mathrm{cm}$ (13 inches) of ponding depth above the media, a $10.16 \mathrm{~cm}$ (4 inches) PVC pipe end cap, and $10.16 \mathrm{~cm}$ (4 inches) of gravel filter media wrapped in filter fabric to prevent migration of the media to the bottom of the column. These column dimensions were selected based on the municipal bioretention cell specifications, but they allow for flexibility for future experimental use as well.

Each column was fitted with a $5.08 \mathrm{~cm}(2 \mathrm{inch})$ circular bulkhead valve that served as the underdrain from each column. Each bulkhead valve was sealed with caulk to prevent leaks, and effluent was directed through a $5.08 \mathrm{~cm}$ (2 inch) PVC pipe. The effluent pipe was fitted with a gate valve and a $300-\mathrm{cm}(0.0117 \mathrm{inch})$ mesh screen to hold the media in the column. Water drained through each column into a separate 18.9 liter (5 gallon) plastic bucket to collect the effluent. 


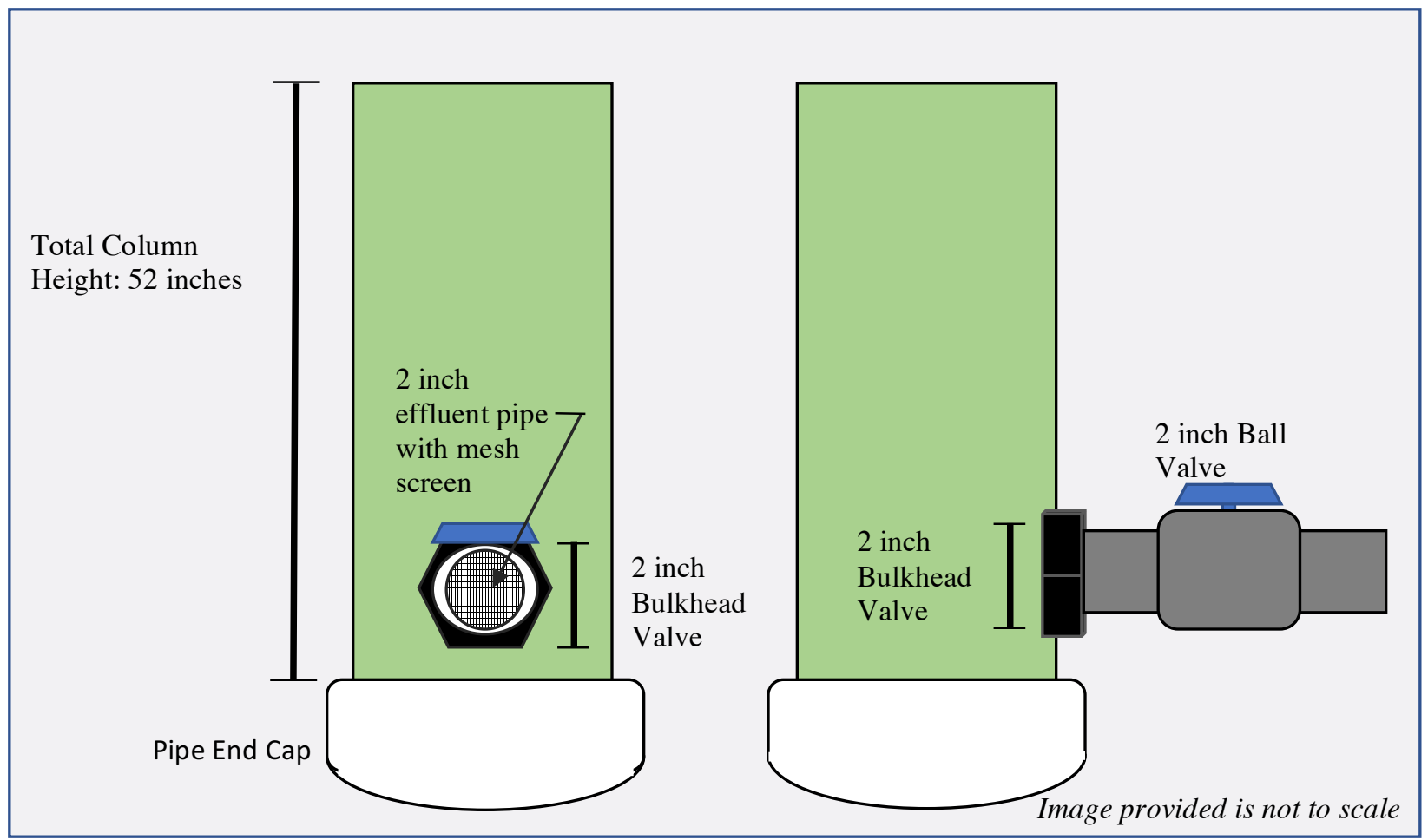

Figure 2: Sample Schematic of the Base of each Soil Column and their drainage system

The columns were seated inside a wooden rack that held each column stable, shown in Figure 3. The rack was constructed of 2 3/4-inch plywood sheets that measured $91.44 \mathrm{~cm}$ by $121.92 \mathrm{~cm}(36$ inches by 48 inches) and had six $26.67 \mathrm{~cm}(10.5 \mathrm{inch})$ holes drilled into them for the columns to be placed. The plywood supports were held by 4 vertical wooden columns constructed out of 2" x 4" lumber. Attached to these columns, 4 lateral wooden support columns constructed out of 2" x 4" lumber were screwed into each plywood sheet. The base of each column was seated on a $410 \mathrm{~mm}$ x $200 \mathrm{~mm}$ x $200 \mathrm{~mm}$ cinder block to raise each column's effluent pipe above the plastic collection bucket. Each column was individually leveled inside the rack using flexible foam tubing to avoid preferential flow through the soil media. 


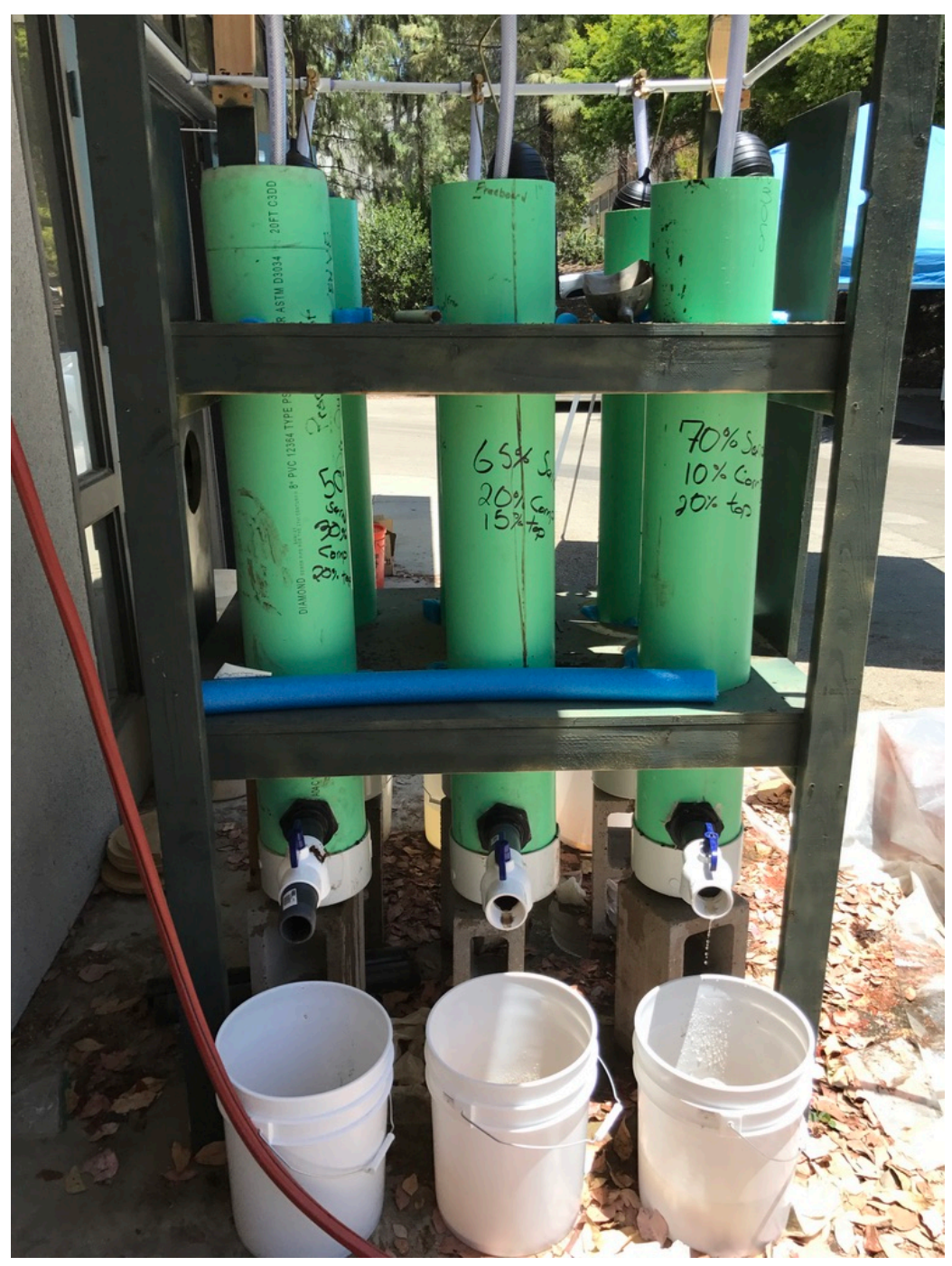

Figure 3: Bioretention Media Columns seated in the Wooden Rack with Float Valves and Distribution Pipes.

Above each column, a pipe network constructed of $1.27-\mathrm{cm}(0.5$ inches $)$ PVC pipe carried water to each column. To provide constant head to each column, each column was fitted with a 1.27 $\mathrm{cm}$ (0.5 inches) brass float valve and float that would stop water flow to the column once the maximum ponding depth in the column was reached. The pipe network was attached to a pump inside a 208-liter (55 gallon) stormwater barrel that served as the reservoir for the water for each 
test. A bypass hose was connected to the pipe network to allow excess flow back into the stormwater barrel and to keep its contents vigorously mixed for the duration of each test.

\subsubsection{Materials Used in Construction}

The columns and end caps used in the construction of the soil columns were purchased and delivered from Ferguson, a local pipe supplier (San Luis Obispo, California). They were delivered in two $609.6 \mathrm{~cm}$ (240 inch or 20 feet) long sections. These sections were cut down to their final $132 \mathrm{~cm}$ (52 inch) size using a chop saw. The piping, plywood, and wooden columns were purchased from Home Depot and were cut to size using a table saw and jigsaw. The brass float valves, the brass rods, and the floats were purchased from Farm Supply. The bulkhead valves were purchased and shipped from Amazon. The $5.08 \mathrm{~cm}$ ( 2 inch) piping that was attached to the bulkhead valves, as well as caulking materials to seal the columns, the mesh to filter out the large particles, and the $5.08 \mathrm{~cm}$ ( 2 inch) ball valves were purchased from Ace Hardware.

\subsubsection{Media Selection}

The media selected for use in this experiment was based on required mix specification standards from five municipalities and county stormwater regulatory agencies, as indicated in Table 1 . The various bioretention soil mixes were also chosen because they would all perform in the semi-arid or Mediterranean climate of California, and would therefore be subject to similar weather patterns. The mixtures consisted of sand, compost, and top soil in various proportions, as listed in Table 1. In addition to the five soil media mixes, a column comprised of $100 \%$ concrete sand (sand that meets the standards set by ASTM C33) was used as a control for the experiment. This would provide a baseline to compare the other media to, and since sand has proven to be an 
effective media ${ }^{12,21}$ a comparison between the mixtures could provide insight into how much sand should be added to bioretention soil mixtures. Table 1 below shows the regulatory requirements for bioretention soil media for each stormwater agency that will be used in this experiment. 
Table 1: Media Compositions of Selected Stormwater Agencies

\begin{tabular}{|c|c|c|c|c|}
\hline Agency & $\begin{array}{l}\text { Column } \\
\text { Number }\end{array}$ & $\begin{array}{l}\text { Percent Sand } \\
\text { (by Volume) }\end{array}$ & $\begin{array}{c}\text { Percent } \\
\text { Compost } \\
\text { (by Volume) }\end{array}$ & $\begin{array}{l}\text { Percent Top Soil } \\
\text { (by Volume) }\end{array}$ \\
\hline Control & 1 & 100 & 0 & 0 \\
\hline $\begin{array}{l}\text { Coastal Watersheds of Los Angeles } \\
\qquad \text { County }{ }^{4}\end{array}$ & 2 & $60-80$ & $20-40$ & 0 \\
\hline $\begin{array}{c}\text { Bay Area Stormwater Management } \\
\text { Agencies Association }^{30}\end{array}$ & 3 & $60-70$ & $30-40$ & 0 \\
\hline $\begin{array}{c}\text { City of Santa Barbara Stormwater } \\
\text { Management Program }{ }^{28}\end{array}$ & 4 & $60-70$ & $15-25$ & $10-20$ \\
\hline $\begin{array}{c}\text { San Diego County Standard Urban } \\
\text { Stormwater Mitigation Plan }{ }^{6}\end{array}$ & 5 & 65 & 15 & 20 \\
\hline $\begin{array}{c}\text { Contra Costa County Clean Water } \\
\text { Program }^{5}\end{array}$ & 6 & $50-60$ & $30-40$ & $10-20$ \\
\hline
\end{tabular}

Note that the specifications for the bioretention media soil mixtures chosen have significant variation in the percentage of sand, compost, and top soil required. This variation in soil composition is expected to create a wide range of behaviors in the nutrient removal, TSS removal, and clean bed effluent characteristics.

Each stormwater agency also outlined specific grain size distributions for the sand, compost, and top soil, as well as organic content, porosity, and minimum hydraulic conductivity of the media. 
These requirements are tabulated below in Table 2 . The requirements for the concrete sand were uniform across the different agencies that had listed grain size distribution requirements. The concrete sand, purchased from a local distributor (Air-Vol Block, San Luis Obispo, California) for use in the columns media met the all listed agency requirements. 
Table 2: Percent Passing Requirements for Sand Compared to AirVol Block Concrete Sand (Control)

\begin{tabular}{|c|c|c|c|c|c|}
\hline & Bay Area Stormwater & Contra Costa Clean & San Diego & Los Angeles & Concrete Sand \\
\hline Sieve No. & Agencies Association & Water Mix A & County & County & (Control) \\
\hline & Column 3 & Column 6 & Column 5 & Column 2 & Column 1 \\
\hline No. 4 & 90 to 100 & 90 to 100 & 90 to 100 & 90 to 100 & $98.3 \%$ \\
\hline No. 10 & 70 to 100 & 70 to 100 & 70 to 100 & 70 to 100 & $82.4 \%$ \\
\hline No. 20 & 40 to 95 & 40 to 95 & 40 to 95 & 40 to 95 & $62.5 \%$ \\
\hline No. 40 & 5 to 55 & 5 to 55 & 5 to 55 & 5 to 55 & $34.1 \%$ \\
\hline No. 60 & - & - & - & - & $14.0 \%$ \\
\hline No. 100 & 0 to 15 & 0 to 15 & 0 to 15 & 0 to 15 & $3.9 \%$ \\
\hline No. 200 & 0 to 5 & 0 to 5 & 0 to 5 & 0 to 5 & $0.3 \%$ \\
\hline
\end{tabular}

\subsubsection{Experimental Bioretention Soil Media}

The soil used when creating these bioretention soil media came from two different local suppliers in San Luis Obispo: Air VolBlock and Ace Hardware. The concrete sand used in the experiment was purchased from Air VolBlock and meets the ASTM C33 standard for grain size distribution and soil characteristics. Additional testing on the soil characteristics was performed to better understand the soils properties (Section 5: Soil Characterization). The compost soil used in the bioretention media columns also was purchased from Air VolBlock. The top soil that was 
used was purchased from Ace Hardware; the blend was advertised as free from any animal and food waste, making it a good selection for bioretention cells.

\subsection{Experimental Procedure and Analysis Methods}

In order to use the testing apparatus described in the section above, a testing procedure was developed to analyze the following aspects of the bioretention soil media:

- Determine how much nitrate and total suspended solids (TSS) are leached from the columns during clean bed testing.

- Determine how effective each bioretention soil medium is at removing influent suspended solids carried by synthetic stormwater.

- Determine how effective each bioretention soil media is at removing nitrates carried by synthetic stormwater.

- Determine how the hydraulic conductivity of the media changes after it is loaded with solids during TSS testing

\subsubsection{Contaminant Loading}

The amount of each contaminant added to the synthetic stormwater is based on "typical" worldwide values shown below in Table 3. The value presented for nitrate and TSS concentrations in stormwater runoff are based on standard values used in other research done on the bioretention soil media and stormwater contaminant concentrations ${ }^{4,13,14,21}$. 
Table 3: Average Influent Concentrations of Stormwater Contamination

\begin{tabular}{cc}
\hline Contaminant & Concentration $(\mathrm{mg} / \mathrm{L})$ \\
\hline TSS & 150 \\
Nitrate as Total Nitrogen (TN) & 2 \\
\hline
\end{tabular}

However, to achieve a higher contaminant loading rate during TSS testing, the average TSS values were doubled to see if clogging would occur in the media.

\subsubsection{Effluent Volume Measurements from the Columns}

To compare the results of the different bioretention soil media, effluent volume was measured in units of pore volumes. This was done for several reasons, most important is that it allows the results from these experiments to be compared to full scale systems. Since the columns have the same depth as a full-scale system and the same media composition, every pore volume that is treated by the bioretention soil media in our test is assumed to behave the same way as a pore volume going through a full-scale system. This means that despite the laboratory scale of this experiment, results from this experiment can be scaled to show the results as a full-scale system. The pore volume measurements also allow all columns to experience the same storm event, and hydraulic conductivity of each of the media can be directly compared as the experiment runs. This means that bioretention soil media with a higher hydraulic conductivity will "treat" more of the influent stormwater, and will have more data because of it. This demonstrates the importance of the hydraulic conductivity of the bioretention soil media since it determines how the volume of water the can be treated per unit area. Depending on the test, pore volumes are collected 
every 3.8 liters ( 1 gallon) or 7.6 liters ( 2 gallons) for TSS and nitrate testing, and every 2 liters for hydraulic conductivity measurements (for more details see Section 3.2.4 below). The calculation of pore volumes is shown in Section 4.1.3, and the table showing the pore volumes of each column are shown below in Table 4. Note that in this table, the percentages of each soil type present in the columns of bioretention soil media are denoted by column number followed by the $\%$ Sand, $\%$ Compost, and $\%$ Top Soil.

Table 4: Pore Volumes of the Bioretention Media Soil Media by Column Number

\begin{tabular}{cccc}
\hline Column Number & $\begin{array}{c}\text { Pore Volume } \\
\text { (liters) }\end{array}$ & $\begin{array}{c}\text { Pore Volume } \\
\text { (gallons) }\end{array}$ & Porosity of the Column \\
\hline $1(100 / 0 / 0)$ & 10.67 & 2.82 & 0.43 \\
$2(80 / 20 / 0)$ & 11.25 & 2.97 & 0.48 \\
$3(60 / 40 / 0)$ & 11.62 & 3.07 & 0.50 \\
$4(70 / 10 / 20)$ & 11.31 & 2.99 & 0.48 \\
$5(65 / 15 / 20)$ & 11.34 & 3.00 & 0.49 \\
$6(50 / 30 / 20)$ & 13.11 & 3.46 & 0.56 \\
\hline
\end{tabular}

\subsubsection{Experimental Procedure for Clean Bed Testing}

To better characterize the media inside each column, a series of clean bed tests were performed before any synthetic stormwater was added to the columns to determine the columns' initial hydraulic conductivity as well as see to what degree the soil mixtures leached both nitrogen and 
total suspended solids (TSS). To perform this clean bed test, the following procedure was developed.

Before each test, a 208-liter (55 gallon) barrel of water was filled from a potable water hose located in the testing area. Once the barrel of water was filled, the pump was lowered into the water where it rested on the bottom of the barrel to pump the water to all the columns. The water was distributed to the columns via the suspended pipe network above the columns, and flowed out into the top of each media layer via hoses. Float valves prevented overflow in each column, but due to the high flow rate of the pump, and the relatively small bypass piping back to the barrel the pump was operated in 30-second off-on cycles as necessary once the columns were filled to avoid overtopping in the columns.

Initially, as flow entered the columns, all flow valves on the effluent pipes were closed and the water was allowed to saturated the columns. Once the water had filled the columns to their maximum ponding depth and the media was saturated, the valves were opened. As the columns began to drain, hydraulic conductivity data was collected by recording the time it took effluent water to fill a 1 quart of a 2-liter painter's bucket. Once the time was noted, samples were collected for analysis and the bucket was emptied into the 19-liter (5 gallon) collection bucket below. All clean bed effluent samples for TSS and nitrate testing were collected every 7.6 liters (2 gallons) in duplicate $50 \mathrm{~mL}$ falcon tube grab samples. For details on how the samples were analyzed see Section 3.2.7 below.

Column effluent results from the clean bed testing were compared to the results from TSS and nitrate influent results to see how the performance of the media changes over the course of the testing. This delineated how much the nitrate or solids the bioretention soil media leaches based 
on characteristics of the media itself compared to the breakthrough, removal, or leaching of contaminants when it is carried by influent stormwater.

\subsubsection{Synthetic Stormwater Preparation}

Two different synthetic storm water mixtures were used for testing: one mixture with controlled nitrate $\left(\mathrm{NO}_{3}\right)$ concentration, and a separate mixture with controlled TSS concentration.

For the nitrate solution, a 1-L stock solution was prepared by adding sodium nitrate (CAS number 7631-99-4), purchased from Fisher Science, to deionized water until a concentration of $875 \mathrm{mg} / \mathrm{L}$ of $\mathrm{NO}_{3}$ was produced. The stock solution was added to 113.6 liters (30 gallons) of tap water inside the 208.2 liter (55 gallon) stormwater barrel to achieve the desired concentration of $6.25 \mathrm{mg} / \mathrm{L} \mathrm{NO}_{3}$, which is equivalent to $2 \mathrm{mg} / \mathrm{L}-\mathrm{N}$ that was desired for this test.

To create the desired concentration for TSS, a blend of top soil and compost were placed on a number 10 sieve and washed with tap water into an 18.9 liter ( 5 gallon) bucket until the soil ran clean. This method allowed smaller particles can be easily carried by stormwater to make up the bulk of the TSS. This water was added to the stormwater barrel and tap water was added to dilute the TSS concentration to the desired level. Average measured concentrations of the influent for both TSS and nitrates are provided in Table 5 below. 


\section{Table 5: Average Measured Influent Concentrations}

\begin{tabular}{ccc}
\hline Pollutant & Concentration $(\mathrm{mg} / \mathrm{L})$ & Standard Deviation \\
\hline Total Suspended Solids (TSS) & 473.6 & 77.26 \\
Nitrate (NO3) as Nitrogen & 1.865 & 0.04 \\
\hline
\end{tabular}

One reason the TSS values showed a high degree of variability is that the pump kept larger particles in suspension than would typically be present in stormwater runoff. To account for this, grab samples from the TSS influent were poured through a number 200 sieve, which stopped larger particles not in suspension from creating falsely high readings.

\subsubsection{Experimental Procedure for TSS and Nitrate Testing}

To test the removal of TSS and nitrates from synthetic stormwater, two different test methods were developed, building on the test method outlined in Section 3.2.3. Before each test, synthetic stormwater was mixed to be applied to the columns. For details on the procedure followed for synthetic stormwater mixtures refer to Section 3.2.4. Each batch of synthetic stormwater was made based on the duration of test that was to be performed since the water was pumped until the pump reached its automatic shutoff depth of $3 \mathrm{~cm}$ (1.18 inches) in the barrel. The smallest volume of water prepared was 208-liter (55 gallon). Additional synthetic stormwater was mixed in 38-liter (10 gallon) containers and added to the barrel and pump as needed to prevent pump shutoff. This allowed the columns to maintain their constant ponding head above the soil media so that each column had the same hydraulic head. 
Once the barrel of synthetic stormwater was filled, the pump was lowered into the water where it rested on the bottom of the barrel to pump the synthetic stormwater to all the columns. The operation of the pump and column followed the procedure outline in Section 3.2.3 above. However, an alteration to this testing method was made during TSS testing, and the pump was suspended by a hose above the bottom of the barrel to avoid drawing fine sand particles into the pump's impeller and potentially damaging it.

Hydraulic conductivity measurements followed the procedure outlined in Section 3.2.6. TSS testing followed the same procedure outlined in the clean bed procedure. The sample collection procedure was altered during nitrate testing. Instead of two $50 \mathrm{~mL}$ grab samples being collected every 7.6 liters ( 2 gallons), two $50 \mathrm{~mL}$ effluent samples were collected in falcon tubes every 3.8 liters (1 gallon) for the first 15.14 liters (4 gallons) of effluent to see if a rapid breakthrough of nitrate occurred in the columns. After the initial 15.14 liters (4 gallons) of effluent were collected, $50 \mathrm{~mL}$ samples were taken every 7.6 liters (2 gallons) for the remainder of the test. For details on how the samples were analyzed see Section 3.2.7 below.

\subsubsection{Hydraulic Conductivity Measurements}

The columns used in the test allowed for a constant head hydraulic conductivity test to be performed. This test allowed the columns to more accurately mimic full-scale systems, which are all designed to have a certain ponding depth to help drive stormwater flows into the media. The equation used to calculate hydraulic conductivity is the following: 


$$
K=\frac{V * L}{A * h * t}
$$

Where: $K=$ Hydraulic Conductivity

$$
\begin{aligned}
& V=\text { Volume of Collected Effluent } \\
& L=\text { Length of the Column } \\
& A=\text { Area of the Column } \\
& h=\text { Head Difference across the Column } \\
& t=\text { Time required to reach Volume } V
\end{aligned}
$$

To test hydraulic conductivity using the bioretention media columns synthetic stormwater effluent from each column was collected in separate 2-liter buckets and measurements were taken once the bucket was filled to the 1-quart marker. The amount of time it took to fill each quart bucket was recorded. The collected data provided a constant volume of effluent $(V)$ and made the only variable that was measured for hydraulic conductivity data the time it took to fill the volume (t). During the testing, the depth to the top of the media was recorded as the constant ponding depth (h). The length of the column (L) and the area of the soil media inside the column (A) were constant values based on the geometry of the columns.

Using this procedure, the hydraulic conductivity tests were run for both clean bed and TSS influent tests to determine the rate at which the system clogged as solids entered the column. This procedure also helped determine if the columns met the regulatory agencies' minimum specified hydraulic conductivity. It also allowed each column's hydraulic conductivity value to be compared to one another despite variation in ponding head as the soils settled in their columns. 


\subsubsection{TSS and Nitrate Analytical Methods}

Once the TSS samples were collected in 50-mL falcon tubes, they were taken to the lab to determine the TSS concentration present in each column. Effluent samples were filtered through $0.2-\mu \mathrm{m}$ pretreated nitrocellulose filters (Hach). Each filter was weighed before testing so the weight of the solids collected could later be calculated. The filters were rinsed in three separate washes of deionized water to avoid shocking the filters. Each filter was placed on a vacuum filtration system, the sample water was poured over the filter, and a vacuum was applied. Filter permeate was collected for nitrate testing for each sample. The nitrocellulose filters were collected in metal trays and baked in an oven at $100^{\circ} \mathrm{C}$ for one hour to remove any excess water on the filters. The dried filters were then weighed and the TSS concentration of each sample was determined based on the following equation:

$$
\text { Concentration }(m g / L)=\frac{\text { Mass }}{\text { Volume }}=\frac{(\text { Filter Weight }+ \text { Soil Weight })-\text { Filter Weight }}{50 m L * 1000 \frac{L}{m L}}
$$

Nitrate concentrations were measured using the filter effluent from the TSS testing. This ensured that the samples did not have solids that would affect the accuracy of the nitrate testing. Nitrate as nitrogen testing was done using an $\mathrm{HACH}$ spectrophotometer and nitrate TNTplus vial test for low range detection, following $\mathrm{HACH}$ procedures. 


\section{Chapter 4 Soil Characterization}

All soils were thoroughly characterized to aid in determining what factors contribute to hydraulic conductivity, nitrate and TSS removal efficiency, and the total pore space available in each column. These factors allow the results from the columns to be applied to full scale systems.

All results in this section label the various columns by volume by a number shown in Figure 4 based on the percentage of sand, top soil, and compost present in the different bioretention media mixtures. In future sections, column descriptions will include both the column number and a short hand abbreviation for the percentages of each soil media constituent present. The short hand will follow the format (percent sand/percent compost/percent top soil) and is also included in Figure 4 below. The soils placed in each column were well mixed by hand before being placed in the column, so each media is a homogenous mixture of the soil portions shown in the Figure below. 
Column 4:

$70 \%$ Sand,

10\% Compost,

$20 \%$ Top Soil

$(70 / 10 / 20)$
Column 5:

$65 \%$ Sand

20\% Compost

$15 \%$ Top Soil

$(65 / 15 / 20)$
Column 6:

$50 \%$ Sand, $30 \%$ Compost, $20 \%$ Top Soil (50/30/20)

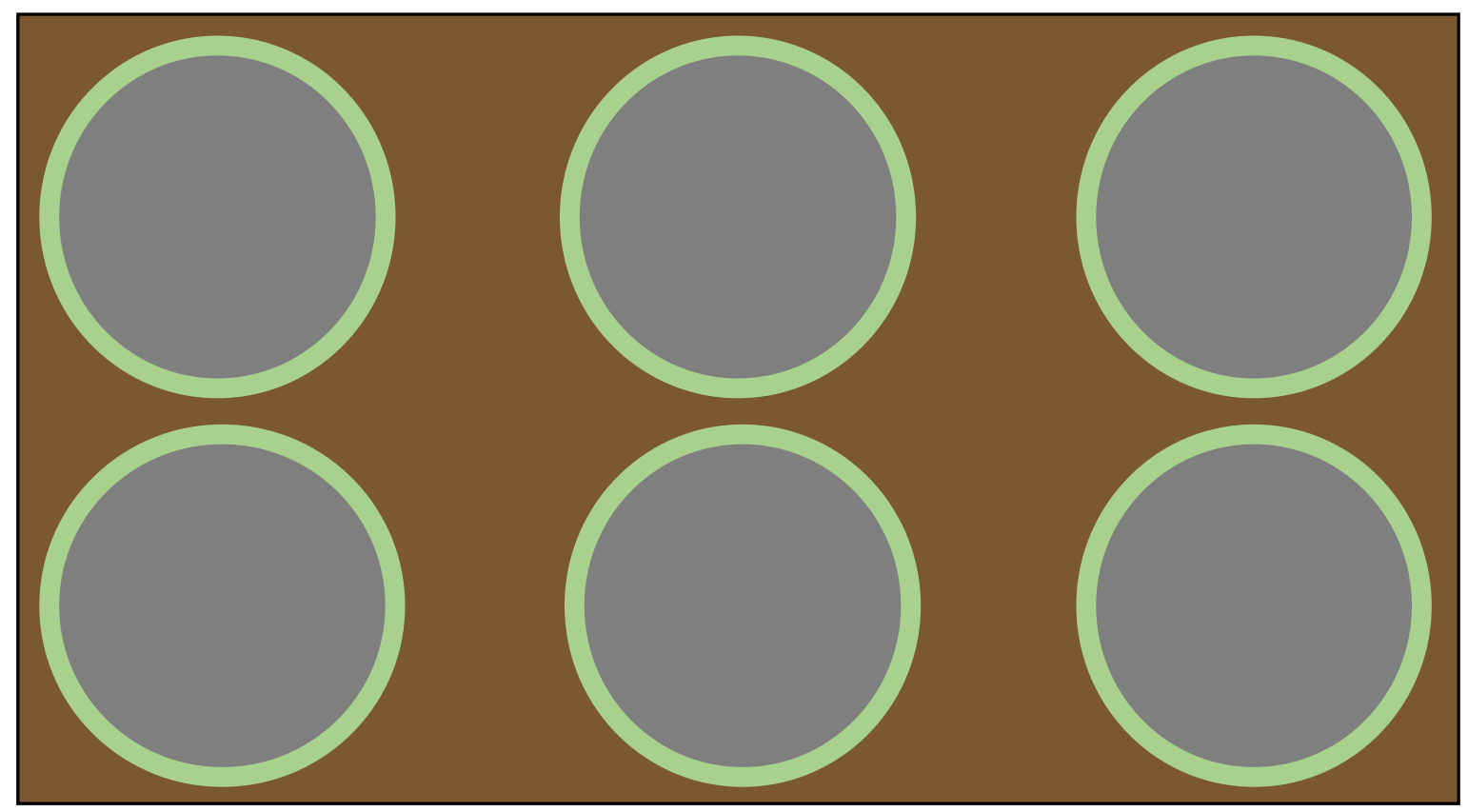

Column 3:

$60 \%$ Sand $40 \%$

Compost

(60/40/0)
Column 2:

$80 \%$ Sand

$20 \%$ Compost

(80/20/0)
Column 1:

Control Column

$100 \%$ Sand

(100/0/0)

Figure 4: Column compositions and numbering with a Plan View Representation of the Columns

\subsection{Soil Characteristics}

Since the removal efficiency and hydraulic conductivity of bioretention soil media is dependent

on the soil characteristics of the media, understanding the soil characteristics and composition of

the media is crucial. This characterization allows for analysis on how soil particles size, organic content, and soil type affect the media performance. Soil characterization also helps create a more repeatable experiment if the properties of the different media can be matched. 


\subsubsection{Specific Gravity of the Media Constituents}

To determine the pore volume available in each column, the specific gravity of each column was calculated. This was especially necessary for the compost and top soil, as both soils contained a significant portion of organics and floating material. Specific gravity was found using a modified version of ASTM Standard D854-14. Four pycnometers were calibrated using the test method to ensure accuracy of the measurement.

To analyze the top soil and the compost, the soil was separated by washing it in a bowl over a number 200 sieve and collecting the material that floated off the soil into the sieve. Floating particles and non-floating particles were analyzed separately due to the significant difference in their specific gravity. An example of the separated soil types is shown below in Figure 5 for the top soil sample. 


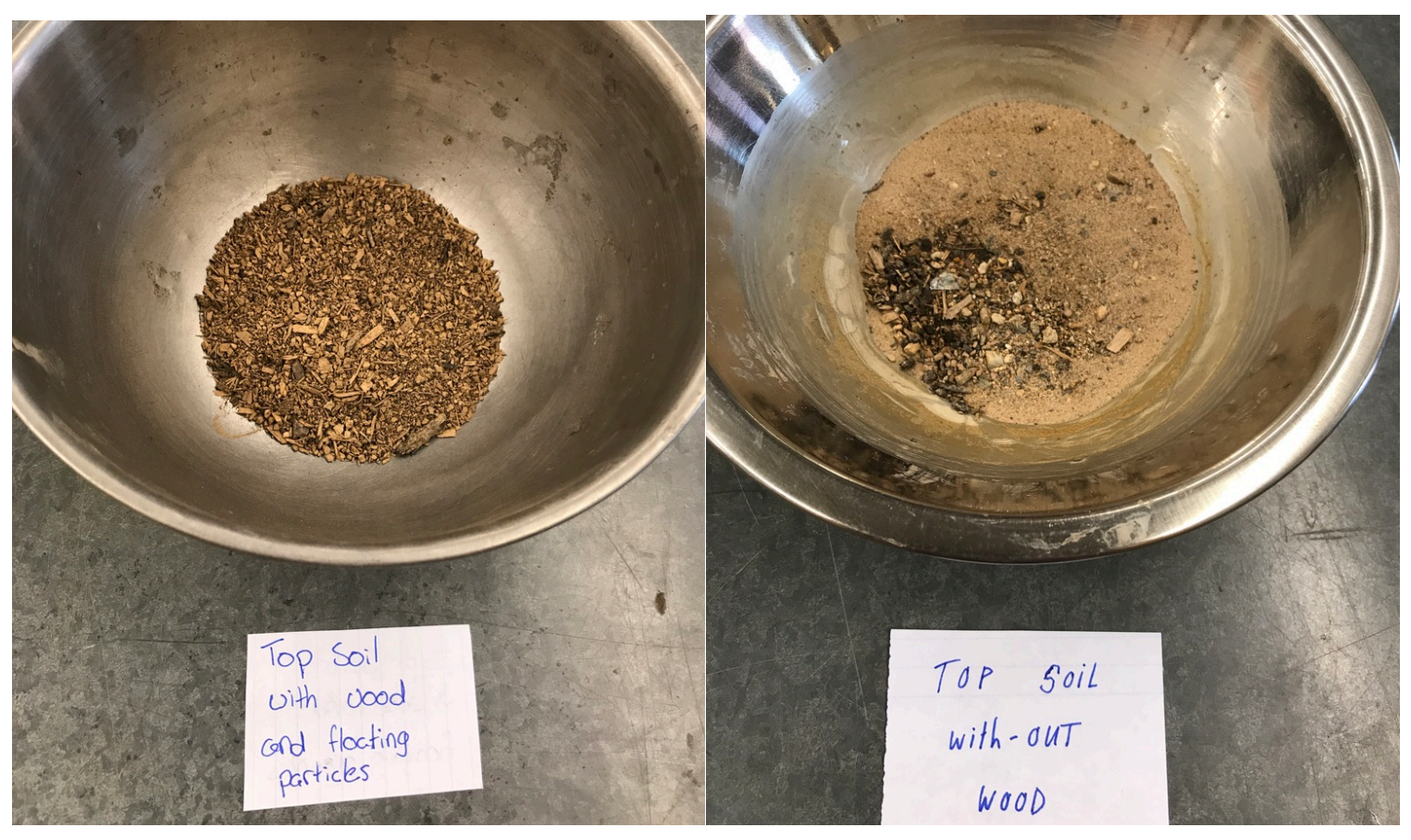

Figure 5: Top Soil Media After Separation

Samples were then saturated in water for 24 hours before the soil was dried to a saturated surface dry condition, or until there is no free water available on the soil particles, to determine absorption of each soil type. Each sample was then added to a pycnometer and placed under a vacuum to remove any trapped air from the media (Figure 6). 


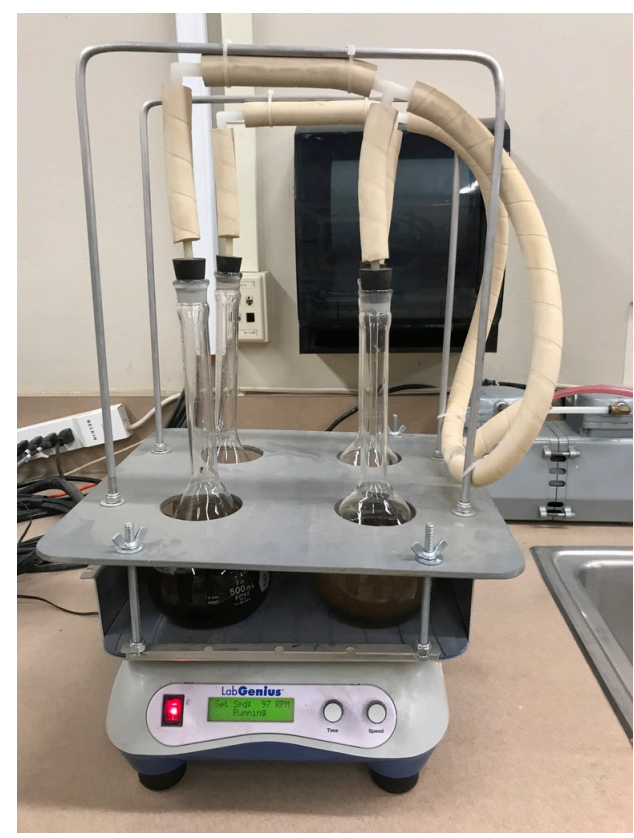

Figure 6: Soil Media in Pycnometers with a Vacuum Pump Applied

Each pycnometer was then weighed before and after water was added to the calibration mark.

Excess floating material in the soil was floated out from the pycnometers prior to weighing to not interfere with the calibration mark reading. This material was collected and oven-dried so no mass would be lost when calculating specific gravity. The samples in the pycnometers were then weighed and oven-dried. Specific gravity was calculated for each of the five soil groups as shown in Table 6 . A combined specific gravity was calculated for top soil and compost by a using a weighted average of the specific gravity of the floating and non-floating soil media shown in Table 7. 
Table 6: Specific Gravity Absorption of Different Soil Media

\begin{tabular}{lcc}
\hline \multicolumn{1}{c}{ Soil Type } & Specific Gravity $\left(\mathrm{g} / \mathrm{cm}^{3}\right.$ at $\left.20^{\circ} \mathrm{C}\right)$ & Absorption \\
\hline Top Soil-Floating Particles & 1.77 & $202.73 \%$ \\
Compost- Floating Particles & 1.83 & $143.42 \%$ \\
Top Soil- Non-Floating Particles & 2.69 & $17.87 \%$ \\
Compost-Non-Floating Particles & 2.42 & $43.96 \%$ \\
Concrete Sand & 2.67 & $12.15 \%$ \\
\hline
\end{tabular}

Table 7: Combined Specific Gravity of the Soil Media

\begin{tabular}{|c|c|}
\hline Soil Type & Specific Gravity $\left(\mathrm{g} / \mathrm{cm}^{3}\right.$ at $\left.20^{\circ} \mathrm{C}\right)$ \\
\hline Top Soil & 2.45 \\
\hline Compost & 2.26 \\
\hline Concrete Sand & 2.67 \\
\hline
\end{tabular}

Based on the specific gravity of the constituents, the specific gravity of each soil in the columns was calculated based on the percentage of each media type added to the column. The specific gravity of the media affects the pore volume available in each media type, with media that has a higher specific gravity having less pore space available. The calculated specific gravity of each column is shown below in Table 8 . 
Table 8: Specific Gravity of Each Soil Media Column Based on Soil Composition

\begin{tabular}{ccccc}
\hline Column Number & $\begin{array}{c}\text { Specific Gravity } \\
\left(\mathrm{g} / \mathrm{cm}^{3} \text { at } 20^{\circ} \mathrm{C}\right)\end{array}$ & Percent Sand & Percent Compost & Percent Top Soil \\
\hline $1(100 / 0 / 0)$ & 2.67 & $100 \%$ & $0 \%$ & $0 \%$ \\
$2(80 / 20 / 0)$ & 2.588 & $80 \%$ & $20 \%$ & $0 \%$ \\
$3(60 / 40 / 0)$ & 2.506 & $60 \%$ & $40 \%$ & $0 \%$ \\
$4(70 / 10 / 20)$ & 2.585 & $70 \%$ & $10 \%$ & $20 \%$ \\
$5(65 / 15 / 20)$ & 2.555 & $65 \%$ & $20 \%$ & $15 \%$ \\
$6(50 / 30 / 20)$ & 2.503 & & & $20 \%$ \\
\hline
\end{tabular}

\subsubsection{Particle Size Distribution}

Using the same separated media for the top soil and compost, a sieve-size analysis was performed using the ASTM D6913 method. The particle size distributions were combined using the Cal Trans California Test 105 method for combining grain size distributions with variation in specific gravities. This method changes the grain size distribution from comparing soils on a "by mass" basis to a "by volume" basis, to account for significant difference in the soil medias' specific gravities. Table 9 and Figure 7 show the grain size distributions of the compost, top soil, and concrete sand. Table 10 and Figure 8 show the grain size distributions of the different bioretention soil mixtures. 
Table 9: Grain Size Distribution for Compost, Top Soil, and Concrete Sand

\begin{tabular}{lccc}
\hline Sieve No. & Concrete Sand $(\%$ & Compost & Top Soil \\
& Passing) & $(\%$ Passing $)$ & \\
\hline No. 4 & $2.84 \%$ & $97.16 \%$ & $97.47 \%$ \\
No. 10 & $9.86 \%$ & $90.14 \%$ & $87.41 \%$ \\
No. 20 & $22.67 \%$ & $77.33 \%$ & $69.70 \%$ \\
No. 40 & & & \\
No. 60 & $40.72 \%$ & $59.28 \%$ & $51.29 \%$ \\
No. 100 & $61.46 \%$ & $38.54 \%$ & $34.82 \%$ \\
No. 200 & $81.35 \%$ & $18.65 \%$ & $19.20 \%$ \\
\hline
\end{tabular}




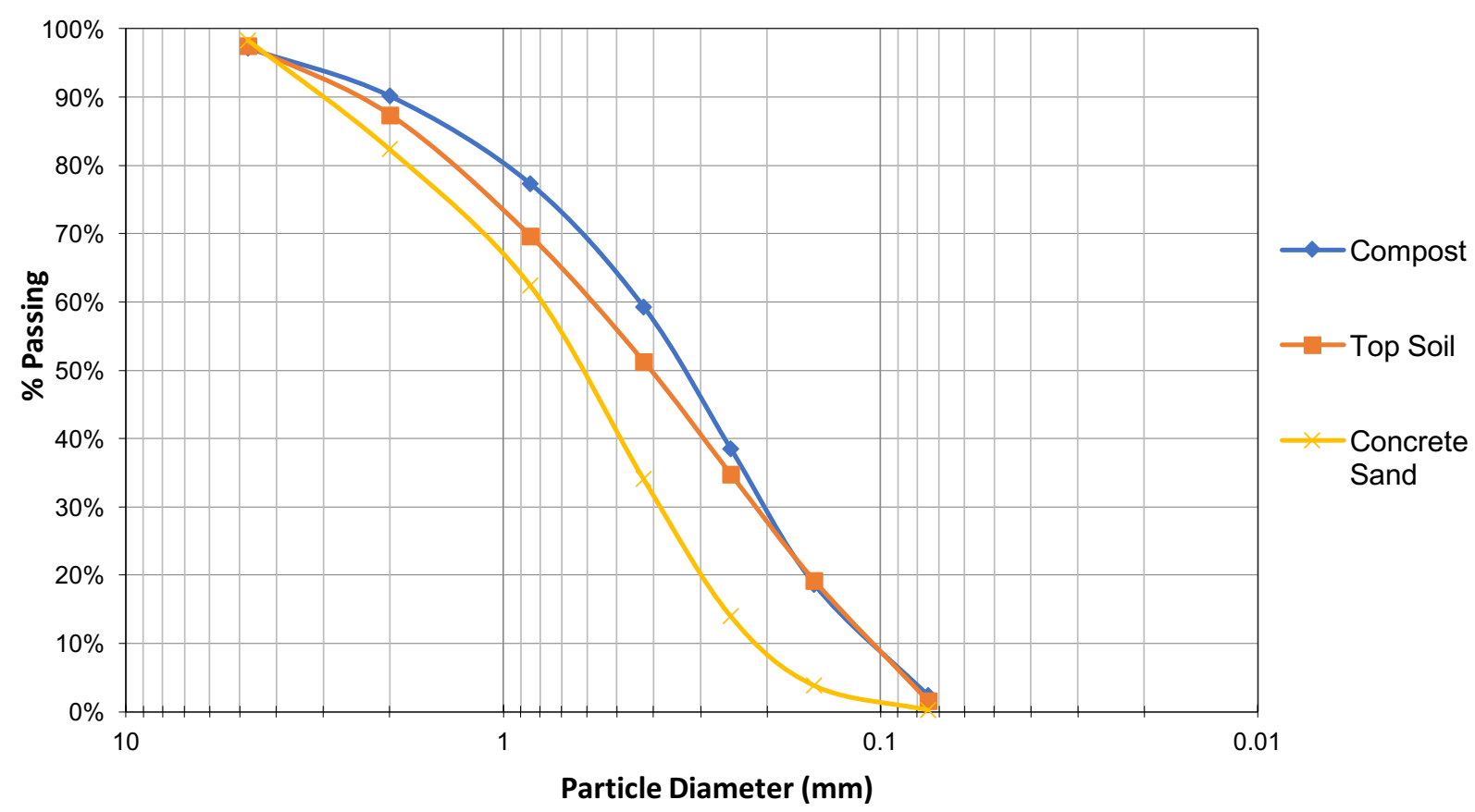

Figure 7: Gradation Curve of Compost, Top Soil, and Concrete Sand 
Table 10: Synthetic Grain Size Distribution of Bioretention Soil Media

\begin{tabular}{|c|c|c|c|c|c|}
\hline & Column 2 & Column 3 & Column 4 & Column 5 & Column 6 \\
\hline Sieve No. ${ }^{1}$ & $(80 / 20 / 0)$ & $(60 / 40 / 0)$ & $(70 / 10 / 20)$ & $(65 / 15 / 20)$ & $(50 / 30 / 20)$ \\
\hline & (\% Passing) & (\% Passing) & (\% Passing) & (\% Passing) & (\% Passing) \\
\hline No. 4 & $92.61 \%$ & $95.65 \%$ & $92.70 \%$ & $93.86 \%$ & $95.74 \%$ \\
\hline No. 10 & $84.88 \%$ & $88.01 \%$ & $73.08 \%$ & $74.52 \%$ & $77.06 \%$ \\
\hline No. 20 & $66.91 \%$ & $69.53 \%$ & $55.57 \%$ & $57.28 \%$ & $60.15 \%$ \\
\hline No. 40 & $42.94 \%$ & $44.90 \%$ & $35.07 \%$ & $37.01 \%$ & $40.87 \%$ \\
\hline No. 60 & $22.56 \%$ & $23.78 \%$ & $18.03 \%$ & $19.52 \%$ & $23.10 \%$ \\
\hline No. 100 & $8.93 \%$ & $9.50 \%$ & $7.25 \%$ & $7.97 \%$ & $10.14 \%$ \\
\hline No. 200 & $1.00 \%$ & $1.07 \%$ & $0.66 \%$ & $0.79 \%$ & $1.06 \%$ \\
\hline
\end{tabular}




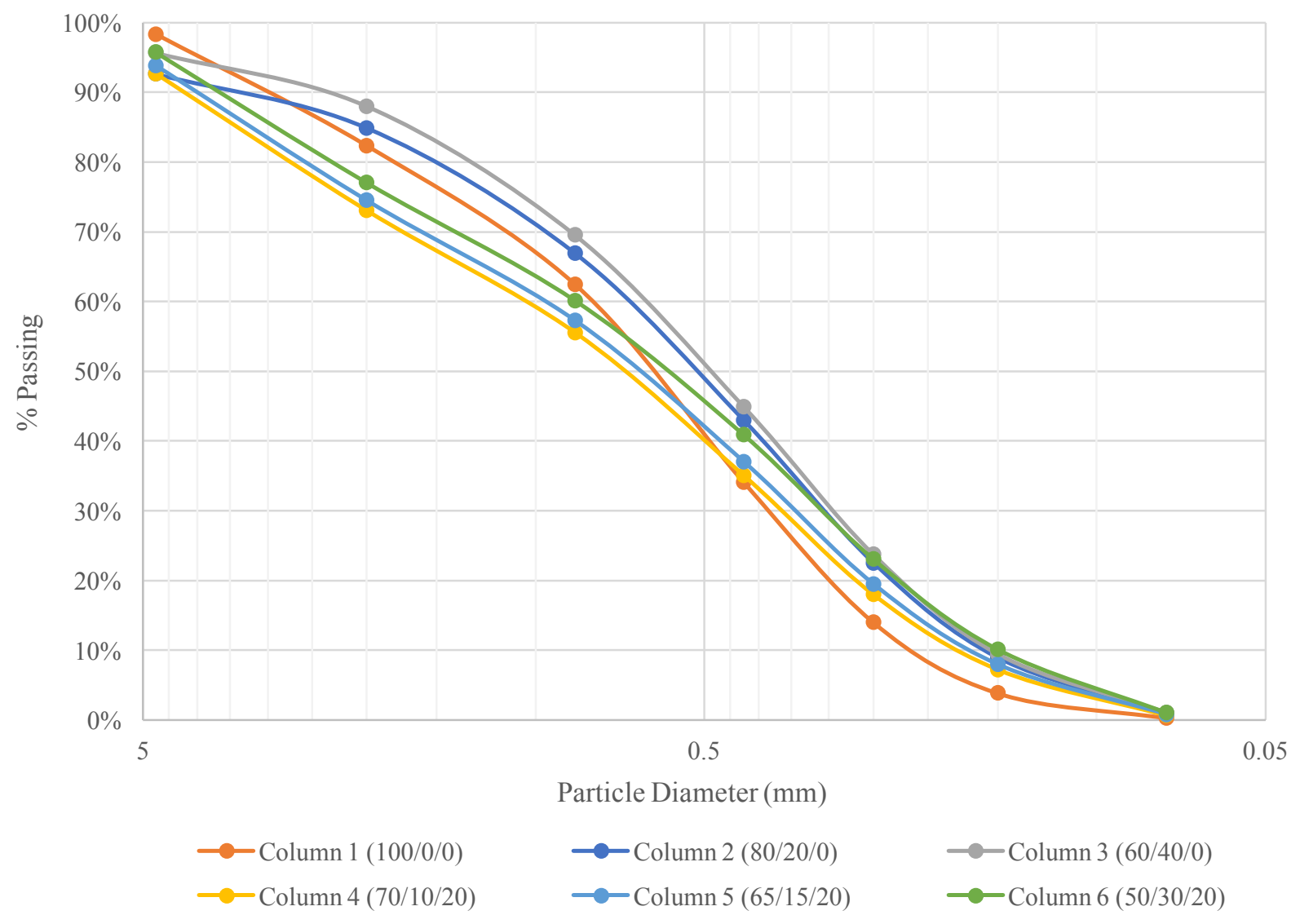

Figure 8: Gradation Curve of the Bioretention Soil Media

Looking at the grain size distributions for the different bioretention soil media, all the soil blends have more fine particles than column $1(100 / 0 / 0)$. The blends that have more compost, columns 2 $(80 / 20 / 0)$ and $3(60 / 40 / 0)$, are comprised of larger material by volume than the other columns. This is likely due to the relatively large wood particles present in the compost which offsets the grain size distribution initially. The bioretention soil mixtures in Columns $4(70 / 10 / 20), 5$ $(65 / 15 / 20)$, and $6(50 / 30 / 20)$ appear to create a well graded soil type, with nearly linear gradation curves compared to the other soil blends. This well-graded characteristic could reduce their 
hydraulic conductivity, due to smaller particles filling the void space created by larger particles making it more difficult for water to travel through the media.

\subsubsection{Pore Volume Determination}

Pore volume was calculated for each column individually based on the mass of soil added, the volume within the column the soil occupied, and the individual soil component's specific gravity. The following relationships were used to calculate pore volume:

$$
\begin{gathered}
M_{\text {Solids }}=\frac{M_{\text {Total }}}{1+\frac{\text { water content (\%) }}{100 \%}} \\
\text { Specific Gravity }=\rho_{\text {bulk }}=\frac{M_{\text {Solids }}}{V_{\text {Solids }}} \Rightarrow V_{\text {solids }}=\frac{M_{\text {Solids }}}{\rho_{\text {bulk }}} \\
V_{\text {Voids (pore volume) }}=V_{\text {Total }}-V_{\text {Solids }}
\end{gathered}
$$

The specific gravity of each soil constituent was calculated using the combined specific gravities listed in Table 8. The volume of solids of each soil component (sand, compost, or top soil) was calculated by using the mass of the component added to the column. The total volume of solids was the sum of all the soil component volumes. The final pore volumes for the columns are listed below in Table 11. 


\section{Table 11: Pore Volumes of the Bioretention Media}

\begin{tabular}{cccc}
\hline Column Number & $\begin{array}{c}\text { Pore Volume } \\
(\text { liters })\end{array}$ & Pore Volume (gallons) & Porosity of the Column \\
\hline $1(100 / 0 / 0)$ & 10.67 & 2.82 & 0.43 \\
$2(80 / 20 / 0)$ & 11.25 & 2.97 & 0.48 \\
$3(60 / 40 / 0)$ & 11.62 & 3.07 & 0.50 \\
$4(70 / 10 / 20)$ & 11.31 & 2.99 & 0.48 \\
$5(65 / 15 / 20)$ & 11.34 & 3.00 & 0.49 \\
$6(50 / 30 / 20)$ & 13.11 & 3.46 & 0.56 \\
\hline
\end{tabular}

\subsubsection{Organic Matter in Bioretention Soil Mixtures}

The amount of organic matter present in each soil mixture is important to quantify due to its potential to leach nitrates out of the soil mixtures and into the effluent ${ }^{24}$. To calculate the amount of organic matter present in each soil column, a modified version of ASTM D2974 - 14 was used. To perform the test, 100 grams of each of the concrete sand, compost, and top soil were oven dried at $100^{\circ} \mathrm{C}$ overnight to remove any excess moisture from the soil. The samples were weighed to the nearest tenth of a gram, and were taken to a furnace to bake at $550^{\circ} \mathrm{C}$ for six hours to volatilize the organic matter present in the soil. The soil was then weighed again to the nearest tenth of a gram. Table 12 below shows the percentage of organic material present in each soil. 


\section{Table 12: Organic Content of Each Soil Constituent}

\begin{tabular}{lc}
\hline Soil Type & Organic Content of Soil by Mass (\%) \\
\hline Top Soil & $14.58 \%$ \\
Concrete Sand & $0.39 \%$ \\
Compost & $29.13 \%$ \\
\hline
\end{tabular}

Based on these measured organic content of the media, the percentage and mass of organic content present in each of the soil mixtures were calculated (Table 13). Included in the Table are the percentages of each soil type in the mixture to show how the percentage of each soil type affects the organic content of each of the media.

Table 13: Organic Content of the Bioretention Soil Media Mixtures

\begin{tabular}{|c|c|c|c|c|}
\hline $\begin{array}{l}\text { Column } \\
\text { Number }\end{array}$ & $\begin{array}{c}\text { Organic Content of Soil } \\
\text { Mixture by Mass (\%) }\end{array}$ & Percent Sand & $\begin{array}{l}\text { Percent } \\
\text { Compost }\end{array}$ & $\begin{array}{l}\text { Percent Top } \\
\text { Soil }\end{array}$ \\
\hline $1(100 / 0 / 0)$ & $0.39 \%$ & $100 \%$ & $0 \%$ & $0 \%$ \\
\hline $2(80 / 20 / 0)$ & $6.14 \%$ & $80 \%$ & $20 \%$ & $0 \%$ \\
\hline $3(60 / 40 / 0)$ & $11.89 \%$ & $60 \%$ & $40 \%$ & $0 \%$ \\
\hline $4(70 / 10 / 20)$ & $6.10 \%$ & $70 \%$ & $10 \%$ & $20 \%$ \\
\hline $5(65 / 15 / 20)$ & $8.27 \%$ & $65 \%$ & $20 \%$ & $15 \%$ \\
\hline $6(50 / 30 / 20)$ & $11.85 \%$ & $50 \%$ & $30 \%$ & $20 \%$ \\
\hline
\end{tabular}




\section{Chapter 5 Clean Bed Results}

Following the characterization of the soil, tap water was run through each column to measure any nitrate and/or TSS leaching. This clean bed testing phase also allowed for gathering the column's baseline hydraulic conductivity before any potential clogging during in the later TSS tests.

\subsection{Total Suspended Solids Leachate during Clean Bed Testing}

The TSS results for the clean bed testing are shown below in Figure 9. The y-axis shows the TSS concentrations in $\mathrm{mg} / \mathrm{L}$ on a logarithmic scale. The $\mathrm{x}$-axis shows the number of pore volumes at which each data point was taken. Due to the nature of the testing apparatus, the total number of pore volumes moved through the system correlate with the hydraulic conductivity of the soil: the higher the hydraulic conductivity, the more data was gathered. For this reason, the data gathered for Columns $5(65 / 15 / 20)$ and $6(50 / 30 / 20)$ is significantly less than the amount of data that was collected in fast flowing media like Columns $1(100 / 0 / 0)$ and $4(70 / 10 / 20)$.

Initial runs of the clean bed testing show very high concentrations of solids leaving the column through the simulated underdrain; every column showed a TSS concentration of at least 100 $\mathrm{mg} / \mathrm{L}$ for the first pore volume. The results for most of the columns stay consistently between 70 and $120 \mathrm{mg} / \mathrm{L}$ of TSS leached. Several spikes in the TSS concentrations are likely not due to a breakthrough of new material, but instead are related to the start of a new set of clean bed testing after the soils dried between runs. This is likely due to smaller soil particles, namely silts and clays, no longer binding to larger heavier particles. This drying and separation process allows the 
small particles to be mobilized during the initial application of water through the columns. These smaller "free" soil particles can move between the pore space of other larger particles and migrate out of the column. This could be responsible for the spikes in TSS seen at the start of each new testing period.

Column $1(100 / 0 / 0)$ had significantly less release of TSS than any of the other columns. Column 1 performed one to two orders of magnitude better than all the columns by the $4^{\text {th }}$ pore volume. By the $6^{\text {th }}$ pore volume, Column $1(100 / 0 / 0)$ shows nearly no TSS breakthrough. This is likely due to the $0.3 \%$ of material in the concrete sand that passes the No. 200 sieve. The lack of smaller particles present in the media meant that there were nearly no particles that could be mobilized through the media after the first several pore volumes of water were applied. The larger soil particles present in the Column $1(100 / 0 / 0)$ also seem to make it easier for smaller particles to move through the column and exit through the underdrain. This is demonstrated in the high initial effluent TSS concertation seen in Column $1(100 / 0 / 0)$. The initial spike in TSS concentration in the first pore volume present in Column $1(100 / 0 / 0)$ is also seen in the Columns $2(80 / 20 / 0)$ and $6(50 / 30 / 20)$, and all three show significantly smaller concentration of TSS during later testing. This could be related to the high hydraulic conductivity in Columns 1 $(100 / 0 / 0)$ and $4(70 / 10 / 20)$, where the faster water velocity more easily removes smaller soil particles. However, the results from Column $6(50 / 30 / 20)$ are more likely due to the small volume of water in which samples were collected and the large percentage of soil that passes the number 200 sieve (1.06\% passing, the largest of any column). The opposite trend is seen in Columns $2(80 / 20 / 0)$ and $5(65 / 15 / 20)$, which have a lower initial TSS concentration than is present in later testing. 


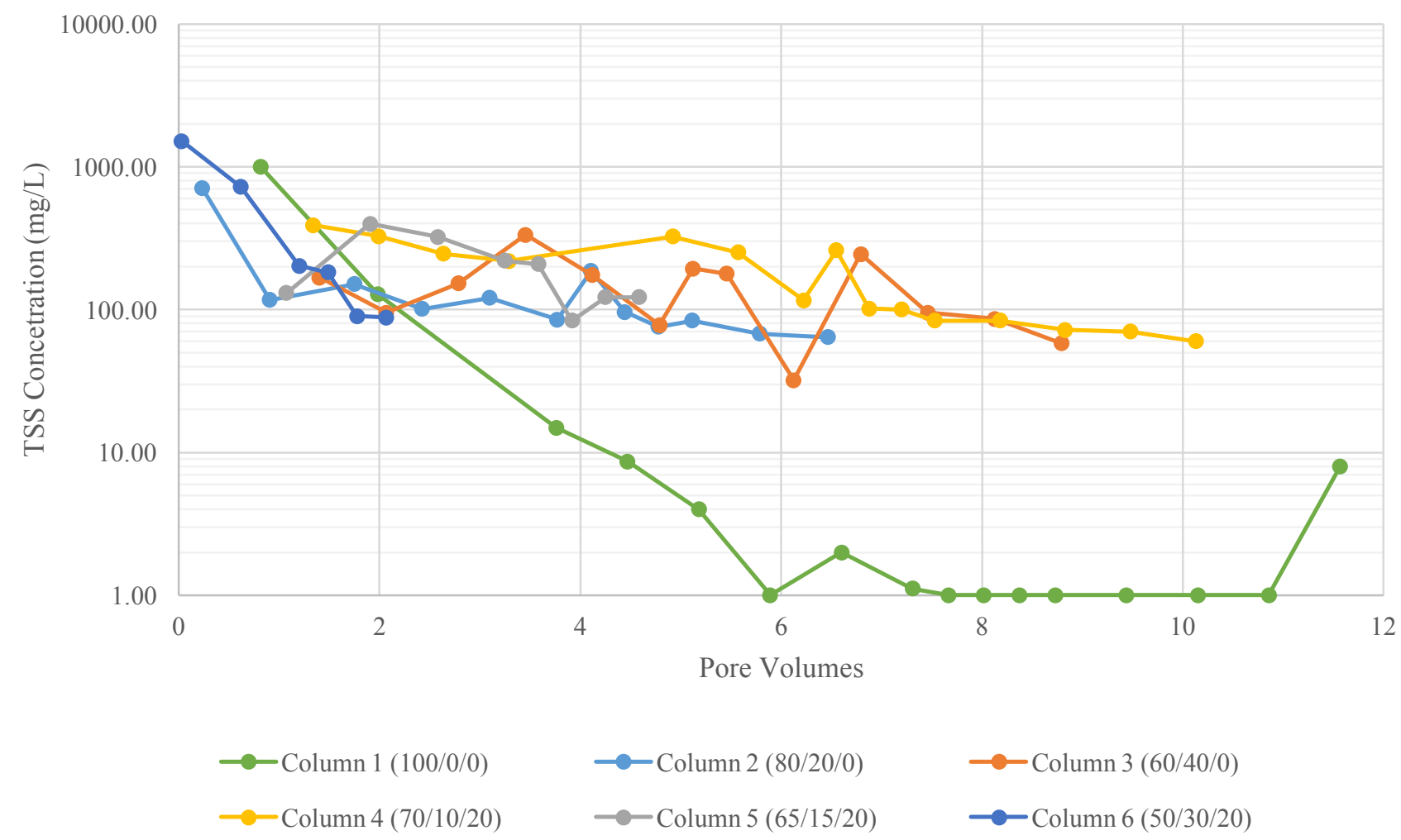

Figure 9: Clean Bed Effluent Concentrations for Total Suspended Solids in each Column

Table 14 below shows the average concentration of TSS leachate from each column, and the average standard deviation during the clean bed testing. Also, as stated above, the first pore volume's concentration of TSS is not necessarily representative of each column's performance over the duration of the test. Therefore, Table 14 includes a column where the first pore volume's data was removed and the averages adjusted. Looking at the results from both cases, columns that used top soil in the bioretention media mixture, Columns 4 (70/10/20), 5 $(65 / 15 / 20)$, and $6(50 / 30 / 20)$, had higher concentrations of TSS leachate on average than columns that were combinations of just sand and compost. However, once the first pore volume of data was removed from Column $6(50 / 30 / 20)$, the average concentration of TSS leachate 
decreased compared to the Columns $4(70 / 10 / 20)$ and $5(65 / 20 / 15)$. This could be due to the well graded nature of the media in Column $6(50 / 30 / 20)$, which makes it better at retaining the finer particles in its soil structure.

Table 14: Average Concentration of TSS Leachate from the Bioretention Soil Media

\begin{tabular}{cccc}
\hline & Average TSS & & Average TSS Leached During Clean \\
Column & Leached During & Standard Deviation & Bed Testing, Excluding the First Pore \\
Number & Clean Bed Testing & $(\mathrm{mg} / \mathrm{L})$ & Volume $(\mathrm{mg} / \mathrm{L})$ \\
& $(\mathrm{mg} / \mathrm{L})$ & & 11.64 \\
\hline $1(100 / 0 / 0)$ & 73.63 & 19.52 & 103.27 \\
$2(80 / 20 / 0)$ & 154.73 & 10.62 & 165.48 \\
$3(60 / 40 / 0)$ & 180.44 & 18.57 & 211.02 \\
$4(70 / 10 / 20)$ & 200.95 & 9.39 & 143.51 \\
$5(65 / 15 / 20)$ & 145.40 & 15.33 & 140.79 \\
$6(50 / 30 / 20)$ & 466.58 & & \\
\hline
\end{tabular}

Based on the clean bed results for TSS, it appears that the best bioretention soil media for minimizing TSS in leachate are the columns that have higher percentages of sand and no top soil. It should be noted that a lower leaching of TSS does not mean that any column is more effective at filtering influent TSS, but only that they are less likely to contribute solids to the effluent migrating out of a column during a rain event. While this is an important distinction in terms of soil mixture behavior, if a large amount of TSS is consistently leached from any column, that 
column's in-situ effectiveness at removing solids from stormwater in order to meet a total daily maximum load (TMDL) is severely limited.

The general trend of the results demonstrates that as more top soil is used, more solids are leached out of the columns. It should be noted however, that because Columns $5(65 / 20 / 15)$ and $6(50 / 30 / 20)$ have such low hydraulic conductivity, the data collected for both columns in this experiment are limited. So, conclusions about their leachate behavior cannot be stated with certainty. However, based on the results after 5 pore volumes of effluent had moved through the columns, all the bioretention media behaved similarly, leaching between 70 and $120 \mathrm{mg} / \mathrm{L}$. This result suggests that any bioretention media will leach a certain concentration of solids as finer particles present in the media continue to drain out over the course of the media's lifetime. The sand control column however leached only $5 \mathrm{mg} / \mathrm{L}$ of TSS after 5 pore volumes, a full order of magnitude less than the other media mixtures used in this test. This result, of a lower leaching of TSS from a pure sand column, seems to indicate the same result as Hsieh and Davis ${ }^{13}$ found that a pure sand mixture had lower TSS effluent concentrations than a mixture with soil and sand. Confirmation of these results during influent TSS testing will be discussed later in Section 6.2.1.

\subsection{Nitrate Leachate during Clean Bed Testing}

Nitrate, or nitrogen leaching from bioretention soil media has been a major concern for municipalities because a net export of nitrate from the media increases the potential detrimental effects the bioretention cell effluent could have on the habitat. Figure 10 below shows the effluent concentration of nitrate (as $\mathrm{N}$ ) on the $\mathrm{y}$-axis in $\mathrm{mg} / \mathrm{L}$ on a logarithmic scale. Again, due to the bioretention mixture in Column $6(50 / 30 / 20)$ having such a low hydraulic conductivity 
data collected from the column is limited. Nitrogen levels in the influent hose water used in this experiment averaged $0.32 \mathrm{mg} / \mathrm{L}$.

Initial nitrogen concentrations from most of the columns show a very high initial release of nitrogen in the first two pore volumes. It seems to reach a nearly constant value for most of the columns after the $3^{\text {rd }}$ pore volume. The general trend for the columns showed that nitrogen leaching decreased as more pore volumes of water went through the soil media. However, Column $6(50 / 30 / 20)$ showed the opposite trend and seemed to leach significantly more nitrogen with each pore volume. However, this result cannot be considered significant since only 3 data points were collected due to the columns low hydraulic conductivity. 


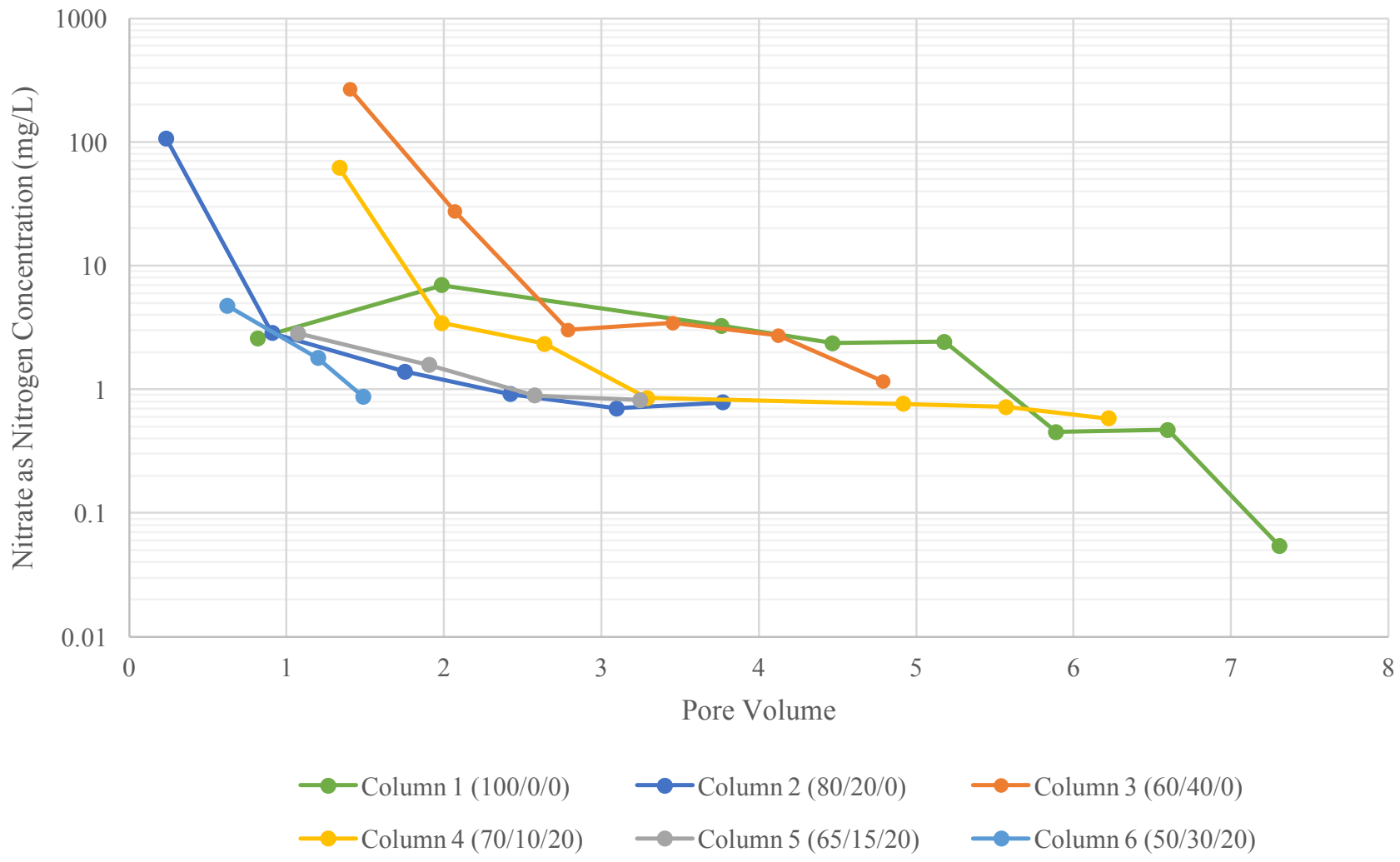

Figure 10: Clean Bed Effluent Concentrations of Nitrate

Table 15 below shows the average concentrations of nitrate leached from each column. 
Table 15: Average Concentration of Nitrate as Nitrogen Leachate from the Bioretention Soil

\section{Media}

\begin{tabular}{ccccc}
\hline & $\begin{array}{c}\text { Average Nitrate } \\
\text { Column }\end{array}$ & Leached During & Average Nitrogen & Standard Deviation \\
Number & $\begin{array}{c}\text { Leached During Clean } \\
\text { Clean Bed Testing } \\
(\mathrm{mg} / \mathrm{L})\end{array}$ & $\begin{array}{c}\text { Standard Deviation, } \\
\text { Bed Testing, Excluding } \\
\text { the First Pore Volume } \\
(\mathrm{mg} / \mathrm{L})\end{array}$ & $\begin{array}{c}\text { Excluding First } \\
\text { Pore Volume } \\
(\mathrm{mg} / \mathrm{L})\end{array}$ \\
\hline $1(100 / 0 / 0)$ & 2.32 & 2.22 & 2.28 & 2.39 \\
$2(80 / 20 / 0)$ & 18.74 & 42.66 & 0.95 & 0.89 \\
$3(60 / 40 / 0)$ & 51.28 & 107.43 & 7.61 & 11.26 \\
$4(70 / 10 / 20)$ & 10.02 & 22.73 & 1.44 & 1.17 \\
$5(65 / 15 / 20)$ & 1.53 & 0.93 & 1.09 & 0.41 \\
$6(50 / 30 / 20)$ & 2.47 & 2.02 & 1.33 & 0.65 \\
\hline
\end{tabular}

For the clean bed results, removing the first pore volume results from the average had a significant impact on the average nitrate leached from each column (Table 15). Using all the values, the best performing column is number $5(65 / 15 / 20)$ which had consistent results from the outset of the test. After removing first pore volume results, the best performing column becomes Column $2(80 / 20 / 0)$. Column $2(80 / 20 / 0)$ has the second lowest percentage of fines and third most organic content out of all the columns. This is an interesting result since organic content is typically related to nitrate leaching ${ }^{21,24}$. 
Instead, based on previous testing ${ }^{18,21}$ it is expected that Column $1(100 / 0 / 0)$, with pure sand would have the lowest nitrogen effluent concentrations, due to its lower organic content. The previous study showed that since sand has fewer nitrates sorbed to the soil than organic matter in soil, it is expected that there would be almost no nitrate leaching from the sand. However, nitrate concentrations in Column 1(100/0/0) effluent were consistently above that of columns 2 $(80 / 20 / 0), 4(70 / 10 / 20)$, and $5(65 / 15 / 20)$ for the first five pore volumes. Column $1(100 / 0 / 0)$ did achieve the lowest concentration present in an effluent sample after its $7^{\text {th }}$ pore volume. Its concentrations decreased dramatically after its fifth pore volume to $0.054 \mathrm{mg} / \mathrm{L}$ of nitrogen leached, a full order of magnitude less than any another column. However, due to the nature of the testing apparatus and sampling methods, this behavior may not be unique to the Column 1 $(100 / 0 / 0)$. Due to the lower hydraulic conductivity present in Columns $2(80 / 20 / 0)$ through 6 $(50 / 30 / 20)$, lower total permeate volumes were collected and therefore their concentrations were not measured. This could mean that the other columns would have lower nitrate concretions at the same pore volume.

\subsection{Hydraulic Conductivity}

Since one of the primary goals of the bioretention cells is to reduce the volume of stormwater runoff, a high hydraulic conductivity of the bioretention soil media is crucial to maximize infiltration. The hydraulic conductivity reported for this experiment is the saturated hydraulic conductivity of the soil media. Table 16 below shows the average hydraulic conductivity of the different bioretention soil media.

The two best performing bioretention soil media in terms of hydraulic conductivity are Columns $1(100 / 0 / 0)$ and $4(70 / 10 / 20)$. Column $1(100 / 0 / 0)$ was expected to have the highest hydraulic 
conductivity because there were fewer fine particles in the media to reduce pore space. It was expected therefore for hydraulic conductivity to be proportional to the percent sand present in each column, with the higher sand percentages causing a higher hydraulic conductivity. This was also expected based on the results from previous experiments ${ }^{12,21}$. This was not the case with column $4(70 / 10 / 20)$, which exhibited higher conductivity than Column $2(80 / 20 / 0)$ despite having less sand and a mixture of compost and top soil. Looking at column 4's (70/10/20) grain size distribution, however, the media mixture has a relatively high $\mathrm{d}_{30}$ and $\mathrm{d}_{10}$, each of which represents the soils effective grain size on the gradation curve, compared to the other media. This indicates that there could be fewer fine particles clogging the pores of Column $4(70 / 10 / 20)$. This trend is not continued for Columns $5(65 / 15 / 20)$ and $6(50 / 30 / 20)$ which had higher $\mathrm{d}_{30}$ and $\mathrm{d}_{10}$ than both Columns $2(80 / 20 / 0)$ and $3(60 / 40 / 0)$, but had significantly lower hydraulic conductivities. Columns $2(80 / 20 / 0)$ and $3(60 / 40 / 0)$, which only used a mixture of compost and sand in different proportions, decreased in hydraulic conductivity by only $20.1 \%$ and $26.2 \%$ compared to the sand respectively. This result suggests that if a higher organic content in the bioretention soil media is desired, the blend should consist of just sand and compost so the higher hydraulic conductivity can be maintained. 
Table 16: Average Concentration of TSS Leachate from the Bioretention Soil Media Mixtures

\begin{tabular}{ccc}
\hline Column Number & $\begin{array}{c}\text { Average Hydraulic } \\
\text { Conductivity }(\mathrm{cm} / \mathrm{hr})\end{array}$ & Standard Deviation $(\mathrm{cm} / \mathrm{hr})$ \\
\hline $1(100 / 0 / 0)$ & 35.9 & 5.809 \\
$2(80 / 20 / 0)$ & 28.4 & 9.637 \\
$3(60 / 40 / 0)$ & 26.49 & 3.557 \\
$4(70 / 10 / 20)$ & 31.87 & 6.948 \\
$5(65 / 15 / 20)$ & 13.19 & 1.543 \\
$6(50 / 30 / 20)$ & 6.53 & 0.391 \\
\hline
\end{tabular}

The minimum specified hydraulic conductivity for bioretention soil media is $5 \mathrm{in} /$ hour $(12.7$ $\mathrm{cm} / \mathrm{hr}$ ) for the City of Santa Barbara Bioretention Soil Media mixture ${ }^{28}$. All bioretention soil media except Column $6(50 / 30 / 20)$ met this minimum requirement in the clean bed testing. 


\section{Chapter 6 Synthetic Stormwater Results and Discussion}

This Chapter presents the results from the column tests where the bioretention soil media columns were dosed with synthetic stormwater containing total suspended solids (TSS) or nitrate. The change of hydraulic conductivity of the bioretention soil media is also considered in this discussion (Section 6.2) due to the potential for TSS to clog the media during stormwater treatment. As with the previous Chapter, all results in this Chapter identify the various columns by column number and blend percentages a table of column numbers and their corresponding soil compositions is shown in Figure 4.

\subsection{Total Suspended Solids Removal}

This section aims to identify which media compositions are most effective at removing TSS from influent synthetic stormwater.

\subsubsection{Total Suspended Solids Results}

A high load of TSS was used during this test to observe the potential for clogging as a result of the high solids loading first flush removal efficiencies that could be expected in the media. Note that none of the columns have enough pore volume data collected to count as long-term results. Influent concentrations had an average TSS concentration of $473.6 \mathrm{mg} / \mathrm{L}$, and are represented by the dark blue line in Figure 11 below. A logarithmic scale was used to better show the high removal efficiencies observed. The best performing media was Column $1(100 / 0 / 0)$ which had a removal rate of over $99 \%$ over the course of the testing. The Columns $2(80 / 20 / 0)$ through 5 (65/15/20) all showed similar removal rates between $90 \%$ and $92 \%$ removal during testing. 
Column 6 performed badly, and had the lowest removal rate of only $73.6 \%$. This result correlated with what was seen during the clean bed testing, the column that used only sand, Column 1, had significantly better removal than the other columns. The bioretention soil mixtures that were predominantly sand, Columns 2 through 5 , had a similar performance with relatively good removal, and Column $6(50 / 30 / 20)$ which was a 50\% mixture of soil (compost and top soil) and sand had the worst performance. This suggest that having a media made up of mostly sand is a better option for TSS removal than blends that use more compost and top soil in their soil mixtures.

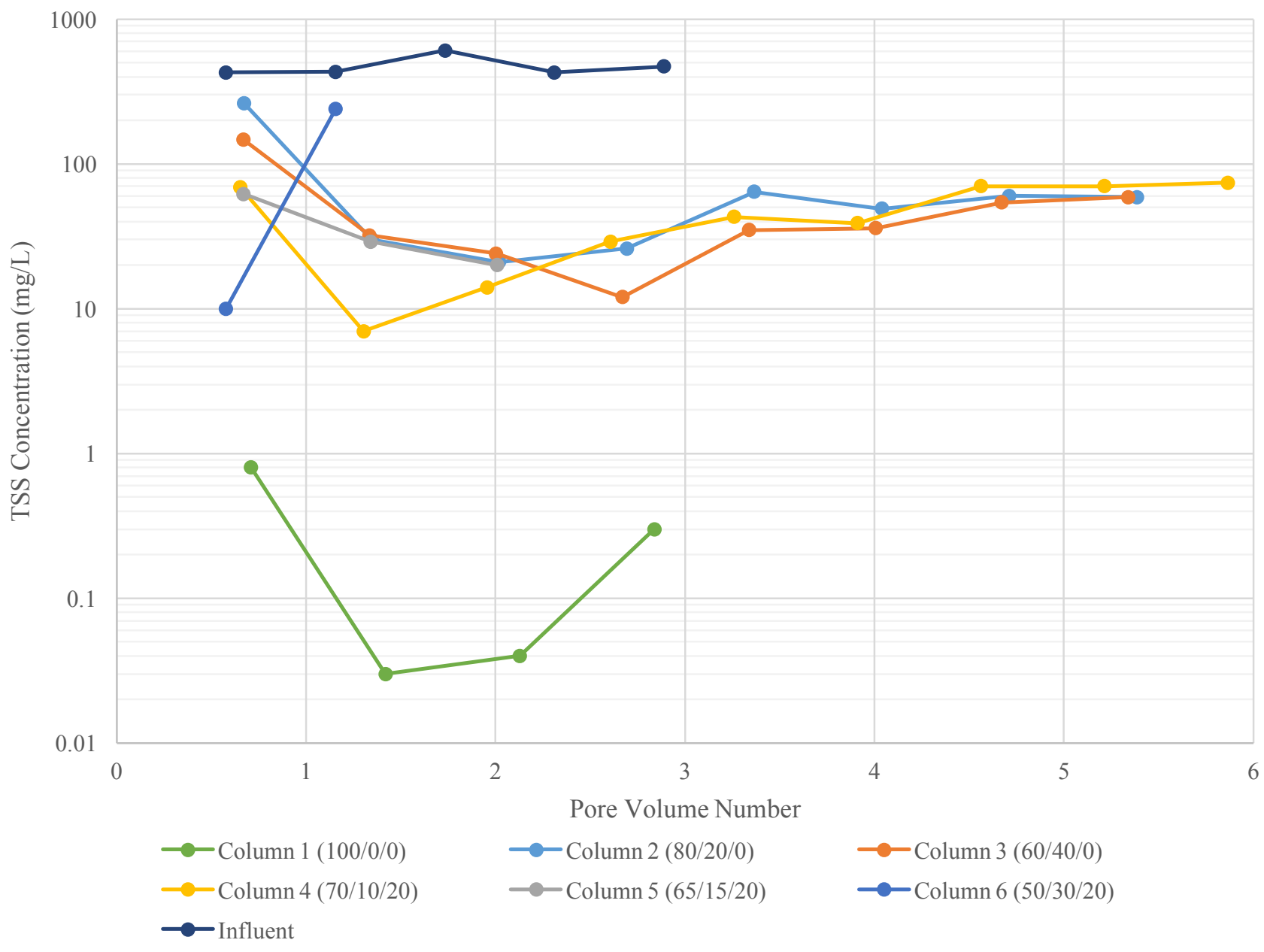

Figure 11: TSS Concentration in the Effluent of Various Bioretention Soil Media 
It should be noted again that because of the design of the testing apparatus used, less data could be collected from the columns with lower hydraulic conductivity. As discussed previously, Column $6(50 / 30 / 20)$ was identified as having a very low hydraulic conductivity which was only exacerbated by the high TSS loading, so results for its ability to remove TSS from influent stormwater are limited.

The percentage of sand and the presence of compost and top soil had significant impacts on the bioretention soil media's ability to filter out solids. Table 18 lists the average effluent concentrations of the columns, their percent removal, and the percent increase or decrease in TSS compared to their clean bed effluent.

Table 17: Average Effluent Concentration in the Bioretention Soil Media During TSS Testing

\begin{tabular}{ccc}
\hline Column Number & $\begin{array}{c}\text { Average TSS in } \\
\text { Effluent (mg/L) }\end{array}$ & $\begin{array}{c}\text { Removal Efficiency from } \\
\text { Influent Concertation }\end{array}$ \\
\hline $1(100 / 0 / 0)$ & 0.29 & $99.9 \%$ \\
$2(80 / 20 / 0)$ & 44.14 & $90.6 \%$ \\
$3(60 / 40 / 0)$ & 46.11 & $90.2 \%$ \\
$4(70 / 10 / 20)$ & 37.00 & $92.1 \%$ \\
$5(65 / 15 / 20)$ & 36.00 & $92.4 \%$ \\
$6(50 / 30 / 20)$ & 125.00 & $73.6 \%$ \\
\hline
\end{tabular}




\subsubsection{Discussion}

Despite the high influent levels of TSS into the columns, the percent removal of solids in all columns' effluent is high, averaging $91.3 \%$ across Columns $2(80 / 20 / 0)$ through $5(65 / 15 / 20)$. Their average removal rate of $91.3 \%$ falls into the expected removal ranges seen in bioretention cells based on the results from previous studies ${ }^{13,14,21,24}$, but confirms the overall results that bioretention cells are good at removing TSS from influent stormwater. Columns $1(100 / 0 / 0)$ and $6(50 / 30 / 20)$ had drastically different performance than the other columns and were higher and lower than typically seen in other studies respectively.

The best performing column in terms of TSS removal, was Column $1(100 / 0 / 0)$ which contained only concrete sand. Again, this result was expected based on the previous research ${ }^{14,21}$ done on bioretention soil media. It is possible that all columns remove a similar concentration of TSS from stormwater, but leach a portion of their fines as the water passes through the column ${ }^{13}$. Column $1(100 / 0 / 0)$ was also expected to maintain the highest hydraulic conductivity based on the clean bed results. However, potentially because of this high removal rate of column 1 , it experienced the most severe clogging of any of the columns. This will be discussed further in Section 6.2.1.

Column $3(60 / 40 / 0)$ had the second highest removal efficiency of any bioretention soil media blends with an average effluent concentration of $36 \mathrm{mg} / \mathrm{L}$ and an average removal efficiency of $92.4 \%$. Since this column had the smallest particle size distribution, the higher removal efficiency was expected, although it was still significantly lower than column 1 . The trend of higher removal efficiency of the media with more fine particles was consistent apart from the two extreme cases in Columns $1(100 / 0 / 0)$ and $6(50 / 30 / 20)$. Column $6(50 / 30 / 20)$ had the 
worst removal efficiency of influent TSS. This result is not entirely unexpected due to the comparatively high concentrations of solids that migrated out of the column during clean bed testing. This result is supported by Hsieh and Davis who found that bioretention soil mixture with a larger portion of soil compared to sand had a chance to leach smaller particles into its effluent ${ }^{13}$. It is possible that none of the influent TSS particles move through the soil media to the effluent pipe, and it instead may be the export of soil already in the media that appears as TSS effluent. However, the export of soil particles, even if they are originally from the bioretention media and were not carried by influent stormwater, must be included in the column's ability to remove TSS since its real-world performance is based on the net export of TSS from the bioretention soil media.

All soil columns saw had an initial breakthrough of solids at the start of the test. This apparent initially low TSS removal efficacy suggests that the initial breakthrough of solids is due more to the migration of particles already present in the soil media column than the influent concentration. This interpretation is consistent with the results from the clean bed testing, which showed a spike in solids concentration whenever a new test was performed, see Section 5.1. Also, the initial spike in concentration from Columns $2(80 / 20 / 0)$ and 3 $(60 / 0 / 0)$ which contained only sand and compost was higher than the initial concentration in Columns $4(70 / 10 / 20), 5(65 / 15 / 20)$, and $6(50 / 30 / 20)$ which had a mixture of sand, compost, and top soil. This suggests that without the presence of both compost and top soil in the bioretention soil media, the compost is more easily mobilized by water in the column. This mobilization leads to an initially higher concertation of solids being leached out of the system for sand and compost combinations. 
The performance of Columns $2(80 / 20 / 0), 3(60 / 0 / 0)$, and 4 (70/10/20) all show similar behavior after the $4^{\text {th }}$ pore volume, with the effluent concentrations between 30 to $80 \mathrm{mg} / \mathrm{L}$. They also all show the same upward trend in concentration as more of the fine influent particles moved through the system and reached the underdrain. The similarity between the results for these columns is interesting since Columns $2(80 / 20 / 0)$ and $3(60 / 40 / 0)$ contain just sand and compost while Column 4 (70/10/20) has a mixture of sand, compost, and top soil.

All columns had reduced TSS concentrations in the effluent compared to the clean bed testing despite the high influent concentration. This reduction is likely due to the removal of the easily mobilized fine soil particles during the clean bed testing. This testing may have "cleaned" the bioretention soil mixture and left only larger particles behind in the media. It could also be due to the constricting of the pore space as the influent TSS particles filled some of the available pore volume, reducing the ability of particles to move through the media. However, this constriction is likely not a significant factor since a constricting of pore space would also reduce hydraulic conductivity of the media. As discussed in Section 6.2 below, this hydraulic conductivity reduction was not observed for most of the media in this experiment.

\subsection{Change in Hydraulic Conductivity Due to Clogging}

With a significant amount of the influent TSS being filtered out by the bioretention soil media it was expected that as the test went on, hydraulic conductivity of the media would decrease due to clogging of pore space by influent TSS as it was captured in the media. This reduction in hydraulic conductivity could be problematic if the media no longer meets its 
specified requirements for hydraulic conductivity and needs to be replaced or undergo maintenance.

\subsubsection{Hydraulic Conductivity Results During TSS Testing}

During the influent TSS testing, hydraulic conductivity data was collected by measuring the time it took for the effluent to fill a 1.89-liter (2 quart) bucket. This allowed us to see if the hydraulic conductivity of the media decreased as sediment was introduced to the system. The figures below show how hydraulic conductivity changed during clean bed and influent TSS testing. Figure 12 below shows the hydraulic conductivity of the media vs the total pore volumes during clean bed testing, while Figure 13 shows the hydraulic conductivity of the media vs the total pore volumes of stormwater that infiltrated through the columns during influent TSS synthetic stormwater testing. 

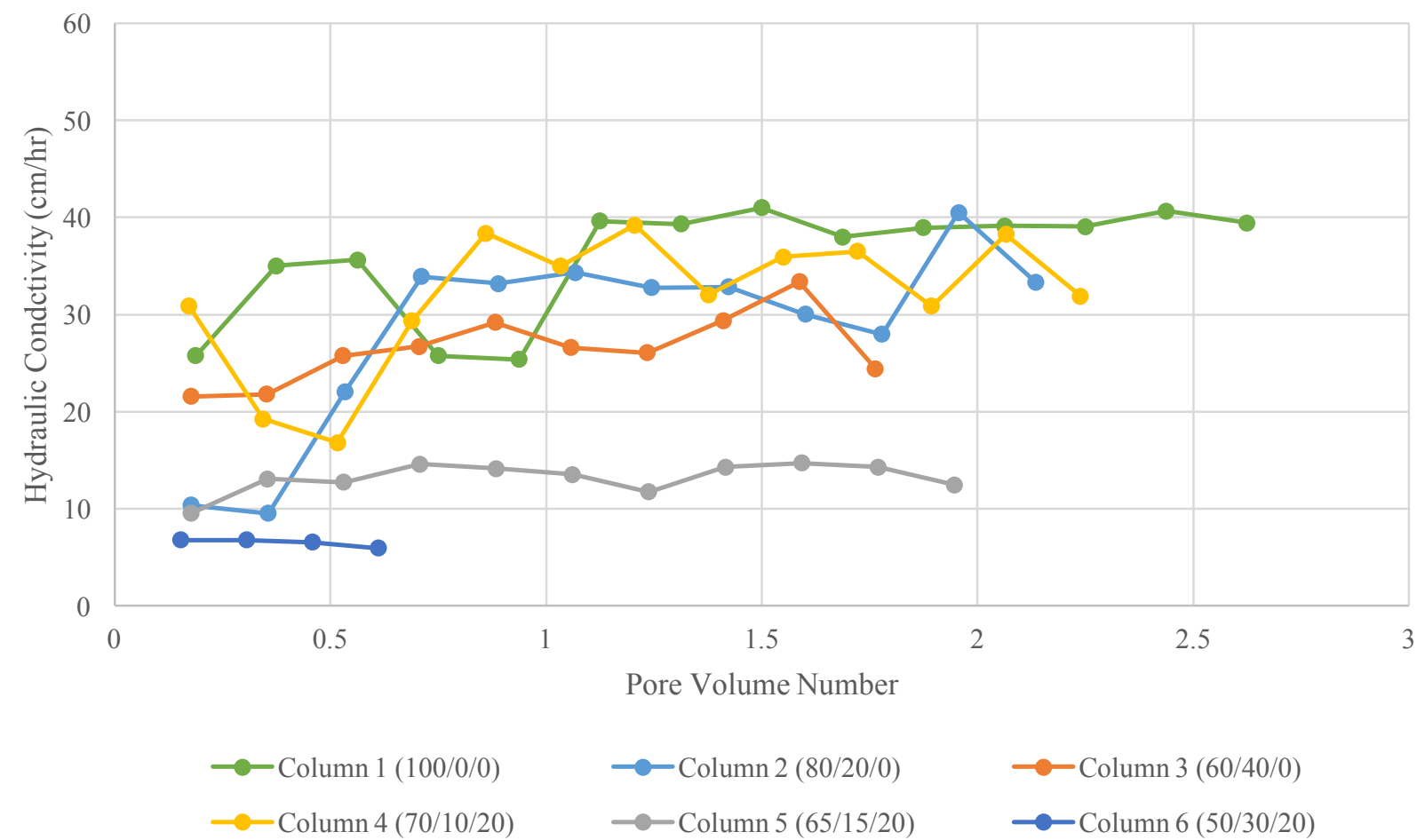

Figure 12: Hydraulic Conductivity of the Bioretention Soil Media During Clean Bed Testing

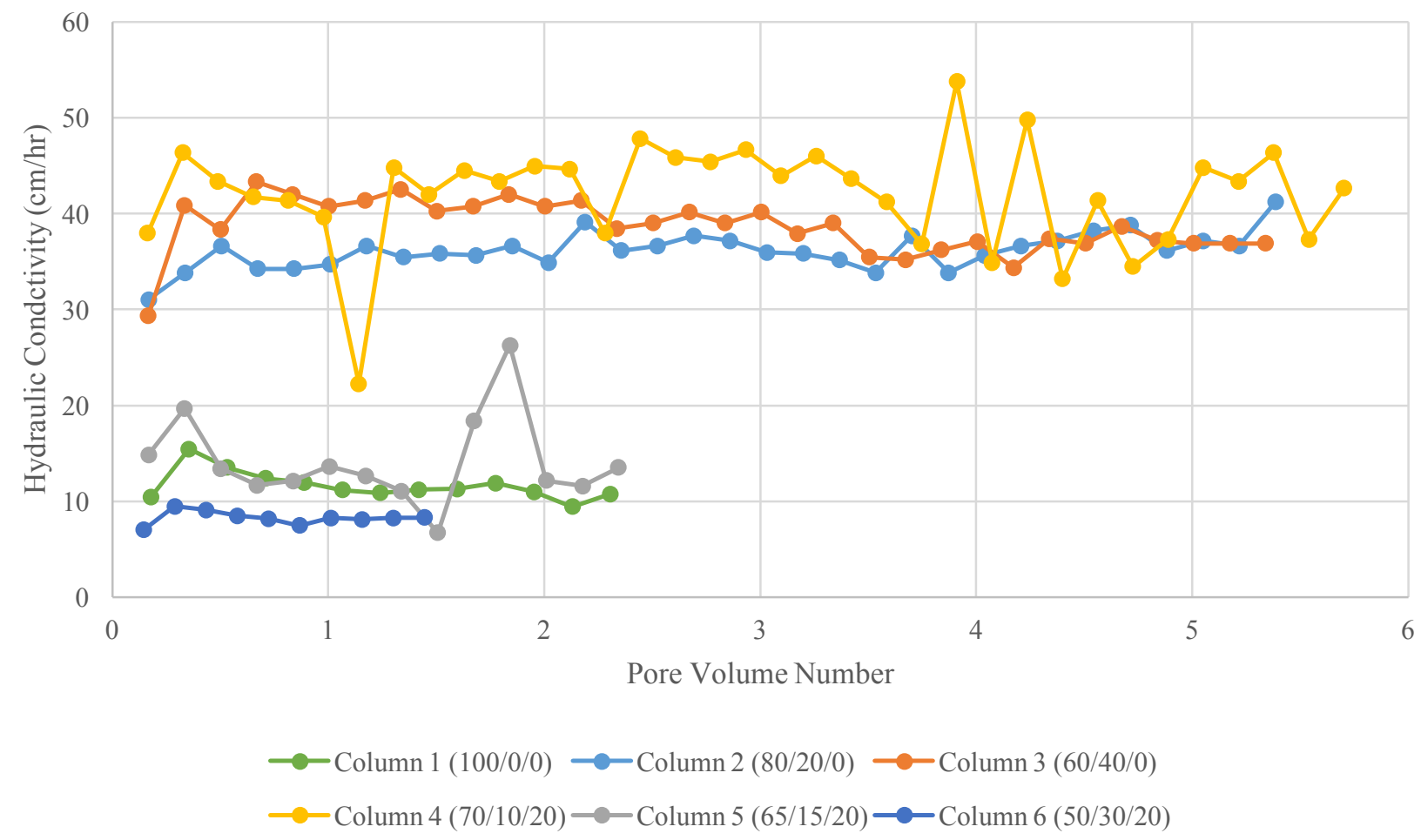


Figure 13: Hydraulic Conductivity of the Bioretention Soil Media During TSS Testing

The bioretention soil media compositions behaved differently during TSS testing than in clean bed testing, and the average hydraulic conductivity of the TSS influent testing is recorded in Table 19 below. The average hydraulic conductivity of clean bed testing and the percent change are also included in the table for an easier comparison of the results.

Table 18: Hydraulic Conductivity of the Bioretention Soil Media During TSS Testing

\begin{tabular}{|c|c|c|c|c|}
\hline & & Average Hydraulic & & Average Standard \\
\hline $\begin{array}{l}\text { Column } \\
\text { Number }\end{array}$ & $\begin{array}{l}\text { Average Hydraulic } \\
\text { Conductivity } \\
\text { During Clean Bed } \\
\text { Testing }(\mathrm{cm} / \mathrm{hr})\end{array}$ & $\begin{array}{c}\text { Conductivity } \\
\text { During TSS } \\
\text { Influent Testing } \\
(\mathrm{cm} / \mathrm{hr})\end{array}$ & $\begin{array}{l}\text { Percent } \\
\text { Change in } \\
\text { Hydraulic } \\
\text { Conductivity }\end{array}$ & $\begin{array}{c}\text { Deviation of the } \\
\text { Hydraulic } \\
\text { Conductivity During } \\
\text { TSS Testing }(\mathrm{cm} / \mathrm{hr})\end{array}$ \\
\hline $1(100 / 0 / 0)$ & 35.9 & 11.6 & $-67.56 \%$ & 1.506 \\
\hline $2(80 / 20 / 0)$ & 28.4 & 36.1 & $27.20 \%$ & 1.888 \\
\hline $3(60 / 40 / 0)$ & 26.49 & 38.6 & $31.87 \%$ & 5.607 \\
\hline $4(70 / 10 / 20)$ & 31.87 & 42.0 & $7.02 \%$ & 4.678 \\
\hline $5(65 / 15 / 20)$ & 13.19 & 14.1 & $45.82 \%$ & 2.848 \\
\hline $6(50 / 30 / 20)$ & 6.53 & 8.3 & $26.63 \%$ & 0.702 \\
\hline
\end{tabular}




\subsubsection{Discussion of Hydraulic Conductivity Results}

Based on the results from the TSS influent testing, the column that used only sand experienced clogging, but the bioretention media did not clog significantly when dosed with high TSS concentration of synthetic stormwater. All the bioretention media mixtures saw an increase in their average hydraulic conductivity, compared to clean bed testing results. Columns $2(80 / 20 / 0), 3(60 / 40 / 0), 4(70 / 10 / 20)$, and $6(50 / 30 / 20)$ saw a significant improvement in hydraulic conductivity compared to the clean bed testing, averaging a $30 \%$ increase on average across the columns. This result is unexpected since we predicted some degradation of hydraulic conductivity as the TSS influent was added to the columns. The only column that experienced significant clogging was column $1(100 / 0 / 0)$, the control column made with $100 \%$ sand. Column 1's (100/0/0) hydraulic conductivity was highest during clean bed testing, and the second lowest after TSS dosing.

The increase in hydraulic conductivity that was observed for the majority of the soil column is likely due to migration of the finer particles that were clogging the soil pores of the bioretention soil media initially into the media's effluent. This migration of the fine media, which is mentioned in Section 6.1.2, is the most likely reason for the increase in hydraulic conductivity for the bioretention soil media. This migration of fine particles also helps to explains why Column $1(100 / 0 / 0)$ reached its peak hydraulic conductivity so quickly during clean bed testing. The smaller portion of fine particles present in the sand were rapidly washed out, which is also supported by the very high initial TSS peak from Column 1 $(100 / 0 / 0)$ in the clean bed TSS results. Additionally, the relatively large pore spaces left between the sand particles could have become filled with the influent solids particles during 
TSS testing, which in turn could be responsible for the rapid decline of hydraulic conductivity seen in the experiment.

The highest hydraulic conductivity of any column after the TSS testing was Column 4 (70/10/20). Since it was believed that the fraction of sand would have the most significant impact on hydraulic conductivity due to its pore $\operatorname{size}^{12}$, it was interesting to see how Columns $2(80 / 20 / 0), 3(60 / 40 / 0)$, and $4(70 / 10 / 20)$ all showed similar hydraulic conductivity despite significant range of sand present in all the medias. Column 2's (80/20/0) hydraulic conductivity increased, but has a very similar hydraulic conductivity to Column $3(60 / 40 / 0)$ despite having significantly less fine media present in the soil mixture. This result, in addition to the results from Column $4(70 / 10 / 20)$, is unexpected based on other research results $^{12}$ which found that larger particles sizes in the soil increased hydraulic conductivity. This result, coupled with the fact that Column $1(100 / 0 / 0)$ suffered severe clogging, suggests that a higher percentage of sand present in the media could mean the media clogs more easily. This clogging could be caused by the larger pore spaces created by the sand being filled with the fine media present in the TSS influent more easily than in the media where the pore spaces are already smaller due to the greater presence of fine soil particles. This may mean that a sand filter is not as effective in the long term compared to a soil and sand mixture for bioretention soil media due to its rapid clogging.

In Columns $5(65 / 15 / 20)$ and $6(50 / 30 / 20)$ where both compost and top soil were added to the mixture, hydraulic conductivity was significantly slower than the three columns which used only compost and sand, despite having a similar amount of sand present in the mixture. This result might suggest that having a high fraction of both top soil and compost present in the media reduces the hydraulic conductivity of the media. However, Column $4(70 / 10 / 20)$ 
which has a combination of top soil, compost, and sand had the highest hydraulic conductivity out of any media in this test. Column $4(70 / 10 / 20)$ does have more sand than Column $5(65 / 15 / 20)$ and $6(50 / 30 / 20)$, and has a higher fraction of top soil compared to compost. It may be that having a higher fraction of compost causes a significant reduction in hydraulic conductivity.

It should be noted that Column $4(70 / 10 / 20)$ had the highest standard deviation during the test, especially in the later trials. This high variability could indicate the initial signs of clogging in this media. Both Columns $2(80 / 20 / 0), 3(60 / 40 / 0), 4(70 / 10 / 20)$ and $5(65 / 15 / 20)$ showed consistent results over the course of the testing period and showed no signs of clogging in their initial pore volumes measurement despite the high loading rate of sediments in the column. In the long term, the mixes in Columns $2(80 / 20 / 0)$ and $3(60 / 40 / 0)$ may be more viable than Column 4 (70/10/20) which showed variation in its results over the course of the testing. Due to the lack of long term data however, this result cannot be concluded with certainty.

The increase in hydraulic conductivity over the course of the testing could also be due in part to the development of preferential flow pathways in the media and along the length of the column. As mentioned in Section 3.1.1, a wider column was chosen to minimize the boundary conditions between the soil and the column. However, settling and movement of the soil during testing may have resulted in flow paths along the walls of the column. If these flow paths developed, water flowing along the edge of the column would have less tortuosity than water flowing through the soil media. This could skew the results showing media with higher hydraulic conductivity than would be possible in a full-scale system. It is expected, however, that all columns would benefit equally from the establishment of preferential flow 
paths — skewing all results by roughly the same factor. Comparing the results to other column and mesocosm studies ${ }^{13,14,19,21,22}$ the column's hydraulic conductivity values fall within the hydraulic conductivity ranges seen in the other tests despite a range of column sizes used in the experiments. So, while preferential pathways may have developed in the media they do not appear to have significantly affected the results of this study compared to other studies.

\subsection{Nitrate Removal}

Based on previous research and the results of the clean bed testing, it was expected that the media with higher organic content would export nitrate from the soil media and cause nitrate concentrations to increase in the effluent ${ }^{15}$. In addition, media without high organic content was expected to see relatively quick breakthrough of nitrates in the media, since they have been shown to be ineffective at removing nitrates, particularly with no vegetation present ${ }^{11}$.

\subsubsection{Nitrate Removal Results}

Knowing that all columns exported nitrate during the clean bed testing, their behavior when dosed with influent nitrate would provide insight to which soil mixtures should a net removal of nitrate. In this experiment, the concentration of nitrate as nitrogen in the effluent samples was compared to the influent concentration of $1.865 \mathrm{mg} / \mathrm{L}$. Modest nitrate removal rates were observed for most of the bioretention soil media in the first two pore volumes that flowed through the media. However, after the first two pore volumes breakthrough, or near breakthrough, of nitrate occurred in half of the columns during testing.

There are three scenarios that are possible from this test. One possibility is net export of nitrate in the column's effluent; which would mean the bioretention soil media acted as a nitrate source, and is the most often seen result in research on bioretention soil media ${ }^{7,13,14,15}$. This was only 
seen in Column $2(80 / 20 / 0)$ in nitrate testing. Second, the effluent concentration could match the influent concentration, which would mean breakthrough of nitrate is occurring and the media is neither exporting nor sorbing nitrates to the water infiltrating through it, which was the most common result seen over the duration of the testing done. The final type of result, which occurred in Columns $5(65 / 15 / 20)$ and $6(50 / 30 / 20)$, was consistent removal of nitrate by the bioretention soil media. This means the soil media is either effectively sorbing or denitrifying the influent nitrates.

The concentration of effluent results from the nitrate as nitrogen testing are shown below in Figure 14. Influent nitrogen values averaged $1.865 \mathrm{mg} / \mathrm{L}$, and are shown in dark blue in Figure 14 , below. The error of the mean is shown for each data point to show the accuracy of the results based on the duplicate testing results. 


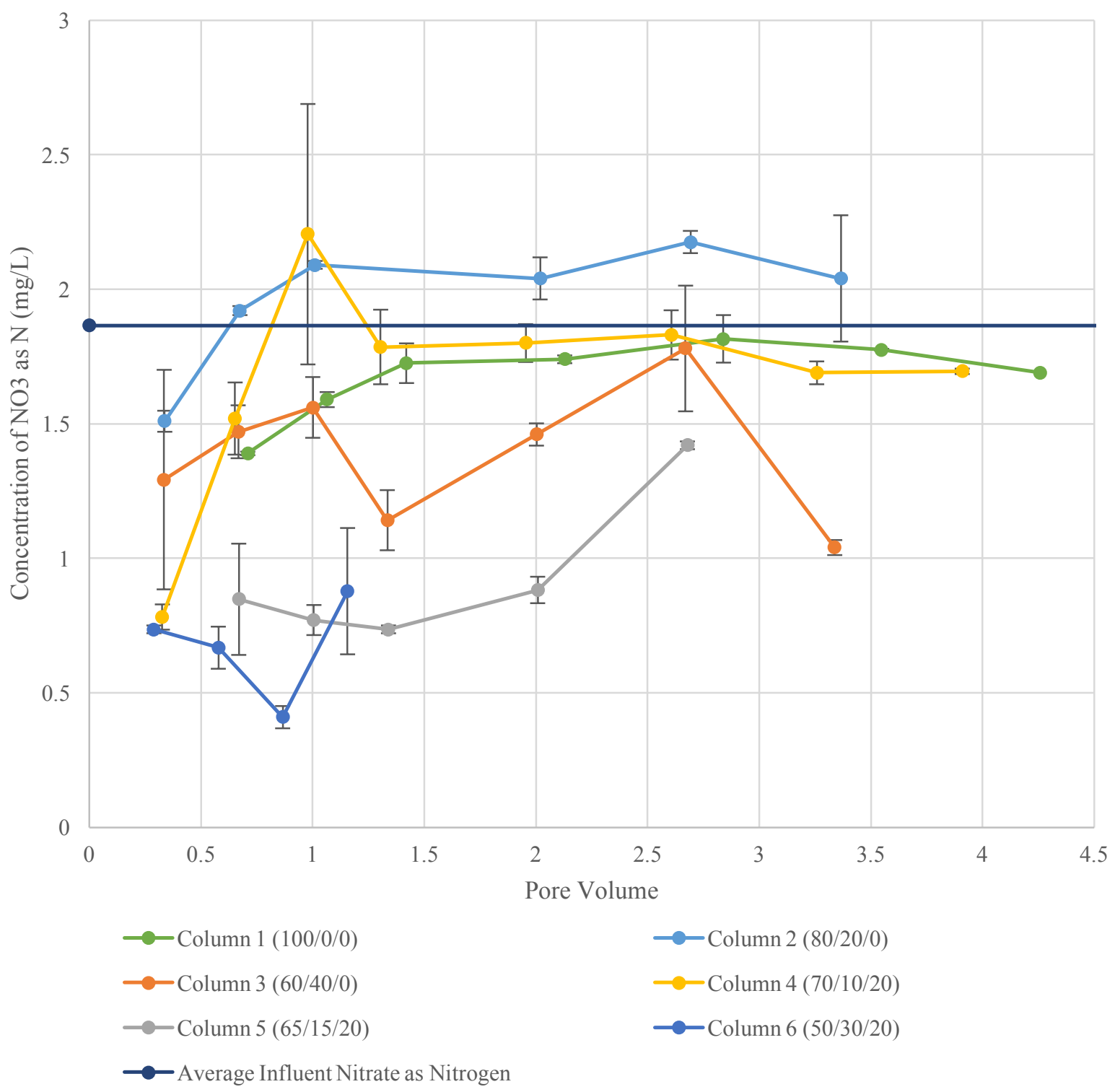

Figure 14: Nitrate as Nitrogen Concentrations of Influent Synthetic Stormwater

The average nitrate as nitrogen concentrations in each column's effluent is shown below in Table 20. The table shows average removal rate of each column for all the data collected for each column. This is meant to show what percentage of the influent nitrate was removed with the varying volumes of water that flowed through each column. 
Table 19: Average Nitrate Removal of the Bioretention Soil Media Columns During Nitrate Testing

\begin{tabular}{lcc}
\hline & \multicolumn{1}{c}{ Average Nitrate } \\
Column Number & Effluent Concentration & Average Percent removal \\
& 1.701 & $10.19 \%$ \\
\hline $1(100 / 0 / 0)$ & 1.845 & $-5.23 \%$ \\
$2(80 / 20 / 0)$ & 1.590 & $25.37 \%$ \\
$3(60 / 40 / 0)$ & 1.829 & $10.81 \%$ \\
$4(70 / 10 / 20)$ & 1.136 & $43.07 \%$ \\
$5(65 / 15 / 20)$ & 0.748 & $63.95 \%$ \\
\hline $6(50 / 30 / 20)$ & & \\
\hline
\end{tabular}

\subsubsection{Discussion}

All the bioretention cell media except column 2 (80/20/0) showed, on average, a removal of nitrate from the influent synthetic stormwater; however, half of the bioretention cell media had less than $10 \%$ removal of influent nitrate within the first two pore volumes. This quick breakthrough of nitrates is consistent with the findings from Bratiéres et al. who saw no effective removal or export of nitrates from bioretention soil media that was tested ${ }^{2}$. Interestingly, many agencies recommend bioretention cells as an effective, or semi-effective, means of reducing nitrates in stormwater, while this result does not support their 
effectiveness. The worst removal of nitrate was from column 2 (80/20/0). After the first half pore volume, it began exporting nitrate into the effluent, and effluent concentration stayed above influent concentration for five out of the six data points collected. Column 4 (70/10/20) reached nitrate breakthrough after just two pore volumes and column $1(100 / 0 / 0)$ reached it after one and a half pore volumes.

The columns that removed the most nitrates were the columns with the lowest hydraulic conductivities. This removal of nitrates could be due to the extended time for sorption to occur on the soil particles, especially since these columns had a higher fraction of smaller particles which have been shown to be more chemically reactive ${ }^{12}$. The higher removal rates could also be due to the high organic content having time to react with and denitrify the influent stormwater. This result is supported by the findings of Hunt et al. who found that having a high organic content and low hydraulic conductivity, or a saturated zone, can create conditions for denitrification and have removal rates of up to $75 \%{ }^{15,23}$. However, it is unclear if the time scale of denitrification is achieved in these columns before the effluent reaches the underdrain and flows out of the column. Some studies state that the water needs up to between 10 and 12 hours to be effectively denitrified ${ }^{15}$, while others think that denitrification could occur as stormwater flows through slower media layers ${ }^{13}$. In both studies, the bioretention soil media that were most effective at removing nitrates had low hydraulic conductivity and high organic content, similar to the soil media tested in this experiment. Results suggest that nitrate removal is inversely related to the hydraulic conductivity of the media, since Columns 1 (100/0/0), $2(80 / 20 / 0), 3(60 / 40 / 0)$, and 4 (70/10/20) all had fairly poor removal of nitrates, but a much higher clean bed hydraulic conductivity compared to Columns 5 and 6. It should be noted that both Columns $5(65 / 15 / 20)$ and $6(50 / 30 / 20)$ have 
less data available than any of the other columns, and both showed effluent nitrate concentrations trending upward during the limited testing, so their ability to remove nitrates may be reduced if more pore volumes are tested.

The results of this experiment are contrary to several studies results ${ }^{2,24}$ which found that a higher fraction of organic content created a nitrate source which could leach into stormwater flowing through the media. Our findings show the opposite trend where a higher organic content typically led to a higher removal rate for nitrates. Previous studies generally found that an increase in organic material resulted in net export of nitrogen in the effluent, especially when no plant matter is present ${ }^{10}$. It should also be noted that the due to the "biogeochemical complexity of the nitrogen species" ${ }^{21}$, it is difficult to assign the removal of nitrates to any one variable that changed between columns. However, based on our test results, nitrate removal appears to be tied to both the hydraulic conductivity and the organic content of the media, with the combination of high organic content and low hydraulic conductivity providing the best removal. In addition, the lack of high nitrate exports from the columns may be due to the testing procedure of this experiment, since a series of clean bed testing was performed prior to a nitrate removal test. In other experiments, higher initial nitrate leaching was thought to be caused by nitrate washout from the columns themselves ${ }^{13}$. By performing clean bed testing and removing the easily mobilized nitrates from the soil, it could have dramatically increased percent removal of the columns in subsequent tests. Looking at section 5.2, initial nitrate leaching during clean bed testing from the columns was higher than the influent concentration during nitrate testing in all column except Column 6 $(50 / 30 / 20)$. 


\section{Chapter 7 Conclusions and Future Work}

This project tested six different bioretention media configurations from various municipal agencies in California to identify their basic soil characteristics and determine their efficiency of removing typical stormwater contaminants. Both total suspended solids (TSS) and nitrates were the primary contaminates of concern for this study due to their prevalence in urban stormwater runoff $^{23}$. Each soil media configuration was placed into a separate soil column following the standards set by each municipality and dosed with synthetic stormwater at a constant head level to determine removal efficiencies and hydraulic conductivity. The preliminary results of the experiment indicate the most effective media in terms of removal of influent TSS, nitrates, and hydraulic conductivity.

\subsection{Conclusions of the Study}

All the bioretention soil media tested in this experiment performed well at removing total suspended solids (TSS) from influent synthetic stormwater with an average removal rate of $88.4 \%$ for all the columns. The most effective mixture at removing TSS, Column $1(100 / 0 / 0)$, removed $99.94 \%$ of the influent TSS in synthetic stormwater, and leached almost no TSS after the five pore volumes of clean bed testing. Columns 2 (80/20/0), $3(60 / 40 / 0)$, and $4(70 / 10 / 20)$ all saw similar TSS removal rates of $90 \%+/-1 \%$ after their $4^{\text {th }}$ pore volume of being dosed with the TSS synthetic stormwater. Column $6(50 / 30 / 20)$ was the worst performing column in terms of TSS removal, but still had relatively high removal rates of $74.91 \%$ of influent sediments. These results confirm the findings of other research that has found bioretention media to be effective at removing TSS from stormwater ${ }^{14,21,24}$. The lower removal rates appear to be related to higher 
fractions of compost and top soil. This result suggests that the lower removal rates seen in Columns $5(65 / 15 / 20)$ and $6(50 / 30 / 20)$ are more of a result their own media washing out of the soil mixture rather than breakthrough of influent TSS particles. This is confirmed by the clean bed testing where Columns $5(65 / 15 / 20)$ and $6(50 / 30 / 20)$ exported soil during the testing, and due to the high percentage of fine particles in the media, continued to export these particles for the duration of the testing. It should be noted that there was no differentiation between the soil leached from the columns and TSS that moved through the columns. In both cases, solids particles would be bypassing the bioretention cell soil media and be carried into a receiving water body - in either case the bioretention cell would not be reducing the contaminant loading so no method for differentiated was necessary.

Nitrate leaching from bioretention cell media causing a negative removal rate of nitrate was a concern for the different media mixtures, especially those with higher organic content present in the media mixture, since this has been a source of nitrogen in other studies ${ }^{24}$. This result seemed to be confirmed during clean bed testing when all columns exported nitrates from the soil media, particularly in columns with higher organic content. During nitrate influent testing, results support literature findings that removal of nitrates in bioretention soil media is highly variable. Column $2(80 / 20 / 0)$ had the worst performance and began leaching nitrate after the first half pore volume, and continued to leach nitrate for the duration of the test. Columns $1(100 / 0 / 0)$ and 4 (70/10/20) saw breakthrough of nitrates in the media after 1.5 pore volumes making them both an ineffective media choice if nitrates are a pollutant of concern. Columns $5(65 / 15 / 20)$ and 6 $(50 / 30 / 20)$ had the best performance in terms of nitrate removal with $39.1 \%$ and $59.9 \%$ of the influent concentration removed respectively. This result was unexpected since the higher organic content present in these two media mixtures was expected to provide a nitrogen source from 
which nitrates would be leached ${ }^{24}$. Both columns also have low hydraulic conductivity so it is unclear whether these results are caused by denitrification ${ }^{15}$ or sorption to the more chemically reactive smaller soil particles ${ }^{12}$. This initial testing suggests that both a lower hydraulic conductivity and a higher organic content result in more effective nitrate removal, and that media with good hydraulic conductivity have limited removal potential for nitrates present in stormwater. This result needs to be confirmed with longer term studies of the media.

The hydraulic conductivity of the media was highly dependent on the sand and soil content in the bioretention soil media, with a higher the sand content typically leading to a higher hydraulic conductivity. This result confirms previous results showing that the larger grain sizes in the sand increased hydraulic conductivity ${ }^{12}$. The media with the highest hydraulic conductivity in the clean bed testing was Column $1(100 / 0 / 0)$ which had an average hydraulic conductivity of 35.9 $\mathrm{cm} / \mathrm{hr}$. However, Column 1 (100/0/0) also experienced the most significant clogging during the TSS influent testing, and its hydraulic conductivity reduced to $11.65 \mathrm{~cm} / \mathrm{hr}$ before the first half pore volume. This is a decrease of over $67 \%$ from the clean bed results. Column $4(70 / 10 / 20)$ had the highest hydraulic conductivity during the TSS influent testing and saw a significant increase in its hydraulic conductivity from $31.874 \mathrm{~cm} / \mathrm{hr}$ to $42.031 \mathrm{~cm} / \mathrm{hr}$. This trend of increasing hydraulic conductivity over the course of the testing was true for all media except Column $1(100 / 0 / 0)$. This counter-intuitive result suggests that as the fine media migrates out of the bioretention soil media, the hydraulic conductivity continues to increase despite the influent TSS being captured in of the soil mixture. How long this trend would continue would be an interesting area of study and is outlined further in section 7.2.1.

Based on the preliminary results shown in this study, some conclusions about the "best" bioretention soil media mixture can be drawn. In addition to the raw results, there are several 
practical considerations that should be made in the final assessment of each media mixture. One of the most important characteristics of any bioretention soil media is its hydraulic conductivity since this directly affects how much stormwater can be removed by the media. If the hydraulic conductivity of the media is too low, then the bioretention cells must either be larger to accommodate the low infiltration rates, or flow will bypass the bioretention cells and send the stormwater and the contaminants it carries directly into receiving water bodies. In addition, bioretention soil media are typically also planted with vegetation to make it more aesthetically pleasing, as well as potentially more effective at removing contaminants like nutrients ${ }^{9}$. Since this study did not include vegetation, these results may not translate directly to field implementation.

Column rankings listed in Table 20 below are based on overall performance in terms of TSS removal, hydraulic conductivity, and nitrate removal. 
Table 20: Ranking of Bioretention Soil Media Columns and their removal rates and hydraulic Conductivity during TSS and Nitrate Testing

\begin{tabular}{|c|c|c|c|c|c|}
\hline $\begin{array}{l}\text { Column } \\
\text { Number }\end{array}$ & Agency & Ranking & $\begin{array}{c}\text { TSS Removal } \\
(\%)\end{array}$ & $\begin{array}{c}\text { Nitrate } \\
\text { Removal (\%) }\end{array}$ & $\begin{array}{l}\text { Hydraulic } \\
\text { Conductivity } \\
\text { (cm/hr) }\end{array}$ \\
\hline $\begin{array}{c}1 \\
(100 / 0 / 0)\end{array}$ & Control & 5 & $99.90 \%$ & $10.19 \%$ & 11.65 \\
\hline $\begin{array}{c}2 \\
(80 / 20 / 0)\end{array}$ & $\begin{array}{c}\text { Costal Watersheds of Los } \\
\text { Angeles County }\end{array}$ & 3 & $90.60 \%$ & $-5.23 \%$ & 36.13 \\
\hline $\begin{array}{c}3 \\
(60 / 40 / 0)\end{array}$ & $\begin{array}{l}\text { Bay Area Stormwater } \\
\text { Management Agencies } \\
\text { Association }\end{array}$ & 1 & $92.40 \%$ & $25.37 \%$ & 38.63 \\
\hline $\begin{array}{c}4 \\
(70 / 10 / 20)\end{array}$ & $\begin{array}{c}\text { City of Santa Barbara } \\
\text { Stormwater Management } \\
\text { Program }\end{array}$ & 2 & $90.20 \%$ & $10.81 \%$ & 42.03 \\
\hline $\begin{array}{c}5 \\
(65 / 15 / 20)\end{array}$ & $\begin{array}{l}\text { San Diego County Standard } \\
\text { Urban Stormwater Mitigation } \\
\text { Plan }\end{array}$ & 4 & $92.10 \%$ & $43.07 \%$ & 14.12 \\
\hline $\begin{array}{c}6 \\
(50 / 30 / 20)\end{array}$ & $\begin{array}{c}\text { Contra Costa County Clean } \\
\text { Water Program }\end{array}$ & 6 & $73.60 \%$ & $63.95 \%$ & 8.27 \\
\hline
\end{tabular}


In terms of an overall most effective bioretention soil mixture, the best performance across all the columns in every category Column $3(60 / 40 / 0)$. While Column $3(60 / 40 / 0)$ was never the top performing media in any category tested, it performed well on all three metrics that were judged in this study. It had a high hydraulic conductivity, second highest after the TSS influent testing, of $38.63 \mathrm{~cm} / \mathrm{hr}$, a removal rate of $92.4 \%$ of the influent TSS, and over the course of the testing did not see a breakthrough of nitrates, and showed an average removal rate of just over $25 \%$. Column 4 (70/10/20) was ranked the next most effective bioretention soil media composition; it had the highest hydraulic conductivity during TSS testing of $42 \mathrm{~cm} / \mathrm{hr}$, a good TSS removal rate of $90.2 \%$, but a poor removal rate of nitrates at just $2 \%$. Column $2(80 / 20 / 0)$ had a similar hydraulic conductivity and TSS removal rate to Column $3(60 / 40 / 0)$, but was the only column shown to leach nitrates across multiple trials during nitrate testing. Column $5(65 / 15 / 20)$ had a low hydraulic conductivity which prevented it from being a very effective bioretention soil mixture. However, it did have good TSS and nitrate removal so it is a viable alternative if the area of the bioretention cell is large enough to handle design storms that flow into it. Column 1 (100/0/0), the sand control column, had excellent clean bed results and has the highest TSS removal, but was ineffective at removing nitrates and saw significant clogging of the soil media. Additionally, it would be unable to support any vegetation, so its practicality as a viable bioretention soil media is questionable. Column $6(50 / 30 / 20)$ had the lowest hydraulic conductivity of any media, and during clean bed testing did not meet the minimum municipal requirement of a $5 \mathrm{~cm} / \mathrm{hr}$ infiltration rate. Column $6(50 / 30 / 20)$ also had the lowest TSS removal rate, although the export of the fine soil particles in the media are likely the result instead of breakthrough of the influent soil particles. Column 6 (50/30/20) did have the highest removal of nitrates despite having the highest organic content, which was an unexpected result. Although, it 
does follow the trend seen of a lower hydraulic conductivity and high organic content showing better nitrate removal during influent nitrate testing. This trend is also supported by the results from Column $5(65 / 15 / 20)$ which had good nitrate removal, a high organic content, and a low hydraulic conductivity.

The most effective option for stormwater agencies to address specific TMDL's or certain contaminants of concern may be to have several bioretention soil mixture standards available based on different design scenarios. These recommendations should be chosen to optimize the type of removal or hydraulic control that would benefit a stormwater agency most in a proposed project site. A decision tree could be utilized to select which type of media would be most effective based on site conditions and site requirements. It is clear from this experiment that there is no "ideal" bioretention media that was tested that performed best in all categories; therefore, a more comprehensive solution to stormwater contamination may not be in one best media, but in a flexible system where a deeper understanding of the different media blends provides an optimal solution to each problem on a site-specific basis.

\subsection{Future Work}

With the initial characterization of the bioretention soil media and development of experiment procedures using the columns discussed in the experiment, the removal efficiency of the bioretention soil media can be expanded in future work. The long-term behavior of these soil mixtures is important to quantify, to allow municipalities to make better informed decisions about the long-term feasibility of these systems. In addition, more work should be done on finding how long it takes for the media to clog and whether the standard practice of removing and replacing the top $10 \mathrm{~cm}$ of soil ${ }^{19}$ will restore the media to its original hydraulic conductivity. 
Finally, this research can be expanded to test the bioretention soil media's removal of additional contaminants such as hydrocarbons, heavy metals, and pathogens.

\subsubsection{Long-Term Behavior of Media}

Determining long-term contaminant removal efficiencies of bioretention soil media is crucial for regulatory agencies since it will dictate both maintenance and total useful lifetime of the media. Extended periods of the synthetic stormwater testing outlined in this report will be required to determine the media's long term behavior. The number of pore volumes until breakthrough for both nitrates and TSS to occur and/or the number of pore volumes it takes the media to become sufficiently clogged should be the next major focus area this testing apparatus should be used for. This study will allow for more accurate and definitive identification of the best soil media for different contaminant loadings. Since the results for this experiment were limited, it is also important to test a more complex "blend" of synthetic stormwater in future tests that introduce more than one contaminant to the media at a time. This additional complexity will make the results more closely mimic in-situ conditions that the bioretention soil media will be exposed to.

\subsubsection{First Flush Analysis}

The first flush phenomenon due to California's Mediterranean climate will cause heavy pollutant loadings to occur annually in bioretention soil media ${ }^{26}$. It is therefore necessary to determine how the media tested in this study will behave when dosed with intermittent high concentrations of contaminates after long periods of drying. By testing this first flush phenomenon, the bioretention soil media can be rated on how effectively it deals with the high concentrations of contaminants, and whether municipalities may expect breakthrough of contaminants in the first storms of the year. The ability to "recharge" the media can also be tested in this study, 
particularly the effectiveness of removing the first few inches of the soil media and replacing it new media.

\subsubsection{Optimization for Further Study of TSS and Nitrate Removal Behavior}

Based on the effectiveness of the various bioretention soil media, the optimal blends from this study can be modified to be more effective at removing specific contaminants. This study would focus on creating different layers of media within each blend that attempt to achieve specific results. Building on the work done by Hsieh and Davis ${ }^{13}$ whose studies created layered media that attempted to create a saturated, slow moving, organic rich zone to denitrify influent stormwater. By creating new blends or layered mixtures, agencies could select a mixture that achieves specific goals for specific project sites depending on the area's TMDL or contaminants present.

\subsubsection{Testing of Other Contaminants of Concern}

Many different contaminants are carried in stormwater including heavy metals, bacteria, oils and greases, and other nutrients. The removal efficiency of the bioretention soil media used in this test for these other contaminants of concern was not addressed in this research. However, the soil columns used in this experiment could be dosed with different blends of synthetic stormwater which carries these different contaminants. This study would also help establish which mixtures were more effective at removing different contaminants, and provide a more detailed reasoning for different municipalities to select certain soil mixtures. 


\section{Works Cited}

1. Brady, N. C., and Weil, R. R. 2002 . The Nature and Properties of Soils, 13th Ed., Pearson Education Inc., Upper Saddle River, N.J.

2. Bratieres, K.; Fletcher, T.D.; Deletic, A.; Alcazar, L.; Le Coustumer, S.; McCarthy, D.T. 2008. Influence of time and design on the hydraulic performance of biofiltration systems for stormwater management. Conference proceedings. 11th International Conference on Urban Drainage, Edinburgh, Scotland.

3. Burns, Matthew J.; Walsh, Christopher J.; Fletcher Tim D.; Ladson, Anthony R.; Hatt, Belinda E. 2015. Ecohydrology, v 8, n 1, p 160-171, January 1, 2015; ISSN: 19360584, E-ISSN: 19360592; DOI:10.1002/eco.1497

4. Coastal Watersheds of Los Angeles County. 2011. Attachment H. Bioretention / Biofiltration Design Criteria. https://www.waterboards.ca.gov/rwqcb4/water_issues/programs/stormwater/municipa 1/la_ms4/Dec5/Order\%20R4-2012-0175\%20-\%20Final\%20Attachment\%20H.pdf

5. Contra Costa Clean Water Program. October 2010. Stormwater C.3 Guidebook Stormwater Quality Requirements for Development Applications. http://www.cccleanwater.org/Publications/Guidebook/Stormwater_C3_Guidebook_5t h_Edition.pdf

6. County of San Diego Low Impact Development Handbook. Appendix G. Bioretention Soil Media Example Specifications. https://www.sandiegocounty.gov/content/dam/sdc/dpw/WATERSHED_PROTECTIO N_PROGRAM/susmppdf/lid_appendix_g_bioretention_soil_specification.pdf

7. Davis, A. P., Traver, R. G., Hunt, W. F., Lee, R., Brown, R. A., and Olszewski, J. M. (2012). "Hydrologic Performance of Bioretention Stormwater Control Measures.” J. Hydrol. Eng., 17(5), in press, 10.1061/(ASCE)HE. 1943-5584.0000467.

8. Davis, A.P., Shokouhian, M., Sharma, H. and Minami, C. 2001. Laboratory Study of Biological Retention (Bioretention) for Urban Storm Water Management, Water 
Environment Research, 73(1), 5-14.

9. Davis, AP; Shokouhian, M; Sharma, H; Minami, C. 2006. Water quality improvement through bioretention media: Nitrogen and phosphorus removal. Water Environment Research 78 (3):284-293.

10. Ermilio, JR, and RG Traver. 2006. "Hydrologic and Pollutant Removal Performance of a Bio-Infiltration BMP.” In World Environmental and Water Resources Congress, 1-12. ASCE. doi:10.1061/40856(200)394.

11. Hatt, B.E.; Fletcher, T.D.; Deletic, A. 2008. Hydraulic and Pollutant Removal Performance of Fine Media Stormwater Filtration Systems. Environmental Science \& Technology 42:2535-2541.

12. Hillel, D. 1998. Environmental soil physics, https://books.google.com/books?hl=en\&lr=\&id=tP_y5xRd0oC\&oi=fnd\&pg=PP1\&d $\mathrm{q}=$ Environmental+soil+physics\&ots=88W6MRmjyq\&sig=EMfsTQ1HS7AifxnaAVyj _lVpEPw $\# \mathrm{v}=$ onepage \& $\mathrm{q}=$ Environmental\%20soil\%20physics\& $\mathrm{f}=$ false

13. Hsieh, CH; Davis, AP; Needelman, BA. 2007. Nitrogen Removal From Urban Stormwater Runoff Through Layered Bioretention Columns. Water Environment Research 79 2404-2411.

14. Hsieh, CH; Davis, AP. 2005. Evaluation and Optimization of Bioretention Media For Treatment Of Urban Storm Water Runoff. Journal of Environmental EngineeringASCE 131 (11):1521-1531.

15. Hunt, W.F., Jarrett, A.R., Smith, J.T., Sharkey, L.J., 2006. Evaluating Bioretention Hydrology and Nutrient Removal at Three Field Sites in North Carolina. Journal of Irrigation and Drainage Engineering-ASCE 132 (6), 600-608.

16. Kadlec, R. H.; Wallace, S. (2009) Treatment Wetlands, 2nd ed.; CRC Press: Boca Raton, Florida.

17. Kim, H.H., Seagren, E.A., Davis, A.P., 2003. Engineered bioretention for removal of nitrate from stormwater runoff. Water Environment Research 75 (4), 355-367.

18. Le Coustumer, S.; Fletcher, T.; Barraud, S. 2008. Influence of Time And Design On The Hydraulic Performance Of Biofiltration Systems For Stormwater Management. Conference proceedings. 11th International Conference on Urban Drainage, 
Edinburgh, Scotland.

19. Lee, G.F.; Jones Lee, A. 1993. Water quality impacts of stormwaterassociated contaminants: Focus on real problems. Water Science and Technology, v 28, n 3-5, p 231-240, 1993; ISSN: 02731223.

20. Li, H; Davis, AP. 2008. Urban particle capture in bioretention media. I: Laboratory and field studies. Journal of Environmental Engineering-ASCE 134 (6):409-418.

21. Limouzin, M.; Lawler, D.; Barrewtt, M. Performance Comparison of Stormwater Biofiltration Designs. Center for Research in Water Resources. http://hdl.handle.net/2152/10905

22. Lucas, W. C., and Greenway, M. (2008). "Nutrient Retention in Vegetated and Nonvegetated Bioretention Mesocosms." J. Irrigation Drain. Engineering, 134(5), 613-623.

23. Manka, B.N.; Hathaway, J.M., Tipak, R.A.; He, Q.; Hunt, W.F.; Driving Forces of Effluent Nutrient Variability in Filed Scale Bioretention Source: Ecological Engineering, v 94, p 622-628, September 1, 2016; ISSN: 09258574; DOI:10.1016/j.ecoleng.2016.06.024

24. Read, J; Wevill, T; Fletcher, T; Deletic, A. 2008. Variation among plant species on pollutant removal from stormwater non biofiltration systems. Water Research 42 (45):893-902.

25. Rick Engineering. June 2014. Summary of Bioretention Soil Specifications for the San Diego Region. https://storage.googleapis.com/centralcoastlidiorg/uploads/BSM\%20for\%20LIDI\%20Memo\%20and\%20Spec_20151.03.12.pdf

26. S.A Dressing, D.W. Meals, J.B. Harcum, J. Spooner. Monitoring and Evaluating Nonpoint Source Watershed Projects. Published May 2016. United States Environmental Protection Agency, Office of Water, Nonpoint Source Control Branch. EPA 841-R-16-010, https://www.epa.gov/polluted-runoff-nonpoint-sourcepollution/monitoring-and-evaluating-nonpoint-source-watershed 
27. Shearer, L.A., J.R. Goldsmith, C. Young, et al. 1972. Methemoglobin levels in infants, in an area with high nitrate water supply. Amer. J. of Public Health, 62:117480.

28. Stormwater Runoff BMP Options. City Santa Barbara Storm Water BMP Guide Manual. 2013; Chapter 6.

http://www.santabarbaraca.gov/civicax/filebank/blobdload.aspx?BlobID=168698.

29. United States Environmental Protection Agency. Preliminary Data Summary of Urban Stormwater Best Management Practices. https://www.epa.gov/nscep. Published 1999. Accessed May 5th, 2017

30. WRA Environmental Consutants. November 2010. Technical Memorandum Regional Bioretetnion Soil Guidance \& Model Specification Bay Area Stormwater Management Agencies Association. https://storage.googleapis.com/centralcoastlidiorg/uploads/Model_BioretentionSoil_Media_Spec_REPORT0.pdf 


\section{Appendices}

This Page is intentionally left blank 


\section{Appendix A: Specific Gravity Testing Results}

\begin{tabular}{l}
\hline SPECIFIC GRAVITY OF SOIL SOLIDS BY WATER PYCNOMETER \\
Test Method: ASTM D854
\end{tabular}

\begin{tabular}{|c|c|c|c|c|c|}
\hline Pycnometer I.D. & Mass of Dry Pycnomter, $\mathrm{g}$ & Mass of Pycnometer and Water, $\mathrm{g}$ & Volume, $\mathrm{ml}$ & Temp, C & Density, $\mathrm{g} / \mathrm{ml}$ \\
\hline 1 & 168.20 & 666.39 & 499.25 & 21.7 & 0.99784 \\
\hline 1 & 168.22 & 666.39 & 499.26 & 21.8 & 0.99782 \\
\hline 1 & 168.22 & 666.67 & 499.43 & 20.8 & 0.99804 \\
\hline 1 & 168.21 & 666.60 & 499.37 & 20.9 & 0.99802 \\
\hline 1 & 168.22 & 666.60 & 499.42 & 21.3 & 0.99793 \\
\hline Average & 168.21 & 666.53 & 499.35 & & \\
\hline Standard Deviation & 0.01 & & & & \\
\hline 2 & 174.48 & 672.37 & 498.97 & 21.7 & 0.99784 \\
\hline 2 & 174.48 & 672.35 & 498.97 & 21.9 & 0.99780 \\
\hline 2 & 174.47 & 672.50 & 499.00 & 20.8 & 0.99804 \\
\hline 2 & 174.47 & 672.45 & 498.96 & 20.9 & 0.99802 \\
\hline 2 & 174.48 & 672.38 & 498.94 & 21.3 & 0.99793 \\
\hline Average & 174.48 & 672.41 & 498.97 & & \\
\hline Standard Deviation & 0.01 & & 0.02 & & \\
\hline 3 & 184.86 & 682.89 & 499.11 & 21.7 & 0.99784 \\
\hline 3 & 184.86 & 682.86 & 499.10 & 21.9 & 0.99780 \\
\hline 3 & 184.86 & 682.99 & 499.11 & 20.8 & 0.99804 \\
\hline 3 & 184.86 & 683.04 & 499.18 & 21.0 & 0.99799 \\
\hline 3 & 184.87 & 682.96 & 499.13 & 21.3 & 0.99793 \\
\hline Average & 184.86 & 682.95 & 499.12 & & \\
\hline Standard Deviation & 0.00 & & 0.03 & & \\
\hline & 185.61 & 683.68 & 499.15 & 21.7 & 0.99784 \\
\hline & 185.61 & 683.66 & 499.14 & 21.8 & 0.99782 \\
\hline & 185.61 & 683.79 & 499.16 & 20.8 & 0.99804 \\
\hline & 185.61 & 683.76 & 499.16 & 21.1 & 0.99797 \\
\hline & 185.61 & 683.69 & 499.11 & 21.3 & 0.99793 \\
\hline Average & 185.61 & 683.72 & 499.14 & & \\
\hline Standard Deviation & 0.00 & & 0.02 & & \\
\hline Tested by: & & Date: & & Checked by: & \\
\hline
\end{tabular}

Note: Standard deviation of dry mass of pycnometer and volume shall be no greater than 0.02 , and 0.05 , respectively. 
SPECIFIC GRAVITY

Test performed in accordance to ASTM D854

\begin{tabular}{|l|l|l|l|}
\hline Job \#: & & Job Name: & \\
\hline Lab Job \#: & & Client: & \\
\hline
\end{tabular}

\begin{tabular}{|c|c|c|c|}
\hline Boring \#: & & Sample \#: & Depth (ft): \\
\hline Soil Description: & Top Soil-Soil & & \\
\hline
\end{tabular}

Initial Moisture Content

(Moist Method)

\begin{tabular}{|l|l|}
\hline Tare I.D. & Top Soil- Soil \\
\hline Tare Mass, g & \\
\hline Wet Mass + Tare, g & \\
\hline Dry Mass + Tare, g & \\
\hline$\%$ Moisture & \#DIV/0! \\
\hline
\end{tabular}

\begin{tabular}{|c|c|c|}
\hline Soil Type & $\begin{array}{c}\text { Moist Mass, g with 250ml } \\
\text { Pycnometer }\end{array}$ & $\begin{array}{c}\text { Moist Mass, g, with } 500 \mathrm{ml} \\
\text { Pycnometer }\end{array}$ \\
\hline $\begin{array}{c}\text { SP, SP- } \\
\text { SM }\end{array}$ & \#DIV/0! & \#DIV/0! \\
\hline SP-SC, & \#DIV/0! & \#DIV/0! \\
SM, SC & \#DIV/0! & \#DIV/0! \\
\hline
\end{tabular}

Note: Values in above table are generated from the reported \% $\mathrm{M}$ and guidance from Table 2 of ASTM D854-06

\section{Pycnomter and Test Data}

\begin{tabular}{|l|c|}
\hline Pycnometer I.D. & 4 \\
\hline Calibrated Volume of Pycnometer, $\mathrm{ml}$ & 499.14 \\
\hline Average Calibrated Mass of Dry Pycnomter, g & 185.61 \\
\hline Mass of Pycnometer+Soil+Water, g & 720.18 \\
\hline Test Temperature, C & 23 \\
\hline Density of Water at Test Temp, g/ml & 0.99754 \\
\hline Temperature Coefficient, $\mathrm{K}$ & 0.99933 \\
\hline
\end{tabular}

\section{After Test Data}

\begin{tabular}{|l|c|}
\hline Tare I.D. & 10 \\
\hline Tare Mass, g & 1045.8 \\
\hline Dry Mass + Tare, g & 1104.18 \\
\hline Mass of Oven Dry Solids, g & 58.38 \\
\hline
\end{tabular}

Calculations

\begin{tabular}{|l|c|}
\hline Mass of Pycnomter and Water at Test Temperature, g & 683.52 \\
\hline Specific Gravity at Test Temperature & 2.69 \\
\hline Specific Gravity at 20 Degrees C & 2.69 \\
\hline
\end{tabular}

\begin{tabular}{|l|l|l|l|l|l|}
\hline Tested By: & Nathan Hanson & Date: & & Checked By: \\
\hline
\end{tabular}




\section{SPECIFIC GRAVITY}

Test performed in accordance to ASTM D854

\begin{tabular}{|l|l|l|l|}
\hline Job \#: & & Job Name: & \\
\hline Lab Job \#: & & Client: & \\
\hline
\end{tabular}

\begin{tabular}{|l|l|l|l|l|}
\hline Boring \#: & \multicolumn{1}{|l|}{} & Sample \#: & & Depth (ft): \\
\hline Soil Description: & Top Soil Wood & \\
\hline
\end{tabular}

\section{Initial Moisture Content (Moist Method)}

\begin{tabular}{|l|c|}
\hline Tare I.D. & Top Soil- Wood \\
\hline Tare Mass, g & \\
\hline Wet Mass + Tare, g & \\
\hline Dry Mass + Tare, g & \\
\hline$\%$ Moisture & \#DIV/0! \\
\hline
\end{tabular}

\begin{tabular}{|c|c|c|}
\hline Soil Type & $\begin{array}{c}\text { Moist Mass, g with 250ml } \\
\text { Pycnometer }\end{array}$ & $\begin{array}{c}\text { Moist Mass, g, with } 500 \mathrm{ml} \\
\text { Pycnometer }\end{array}$ \\
\hline $\begin{array}{c}\text { SP, SP- } \\
\text { SM }\end{array}$ & \#DIV/0! & \#DIV/0! \\
\hline SP-SC, & \#DIV/0! & \#DIV/0! \\
SM, SC & \#DIV/0! & \#DIV/0! \\
\hline
\end{tabular}

Note: Values in above table are generated from the reported \%M and guidance from Table 2 of ASTM D854-06

Pycnomter and Test Data

\begin{tabular}{|l|c|}
\hline Pycnometer I.D. & 2 \\
\hline Calibrated Volume of Pycnometer, $\mathrm{ml}$ & 498.97 \\
\hline Average Calibrated Mass of Dry Pycnomter, g & 174.48 \\
\hline Mass of Pycnometer+Soil+Water, g & 681.14 \\
\hline Test Temperature, C & 22.8 \\
\hline Density of Water at Test Temp, g/ml & 0.99759 \\
\hline Temperature Coefficient, K & 0.99938 \\
\hline
\end{tabular}

\section{Calculations}

\begin{tabular}{|l|c|}
\hline Mass of Pycnomter and Water at Test Temperature, g & 672.25 \\
\hline Specific Gravity at Test Temperature & 1.77 \\
\hline Specific Gravity at 20 Degrees C & 1.77 \\
\hline
\end{tabular}

After Test Data

\begin{tabular}{|l|c|}
\hline Tare I.D. & 7 \\
\hline Tare Mass, g & 1045.52 \\
\hline Dry Mass + Tare, g & 1066.02 \\
\hline Mass of Oven Dry Solids, g & 20.50 \\
\hline
\end{tabular}

Tested By:

Nathan Hanson

Date:

Checked By: 


\section{SPECIFIC GRAVITY}

Test performed in accordance to ASTM D854

\begin{tabular}{|l|l|l|l|}
\hline Job \#: & & Job Name: & \\
\hline Lab Job \#: & & Client: & \\
\hline
\end{tabular}

\begin{tabular}{|l|l|l|l|l|l|}
\hline Boring \#: & \multicolumn{2}{|l|}{} & Sample \#: & & Depth (ft): \\
\hline Soil Description: & Compost-Soil & \\
\hline
\end{tabular}

\section{Initial Moisture Content} (Moist Method)

\begin{tabular}{|l|c|}
\hline Tare I.D. & Compost Soil \\
\hline Tare Mass, g & \\
\hline Wet Mass + Tare, g & \\
\hline Dry Mass + Tare, g & \\
\hline$\%$ Moisture & \#DIV/0! \\
\hline
\end{tabular}

\begin{tabular}{|c|c|c|}
\hline Soil Type & $\begin{array}{c}\text { Moist Mass, g with 250ml } \\
\text { Pycnometer }\end{array}$ & $\begin{array}{c}\text { Moist Mass, g, with } 500 \mathrm{ml} \\
\text { Pycnometer }\end{array}$ \\
\hline $\begin{array}{c}\text { SP, SP- } \\
\text { SM }\end{array}$ & \#DIV/0! & \#DIV/0! \\
\hline SP-SC, & \#DIV/0! & \#DIV/0! \\
SM, SC & \#DIV/0! & \#DIV/0! \\
\hline Silt or Clay & & H \\
\hline
\end{tabular}

Note: Values in above table are generated from the reported \%M and guidance from Table 2 of ASTM D854-06

\section{Pycnomter and Test Data}

\begin{tabular}{|l|c|}
\hline Pycnometer I.D. & 2 \\
\hline Calibrated Volume of Pycnometer, $\mathrm{ml}$ & 498.97 \\
\hline Average Calibrated Mass of Dry Pycnomter, g & 174.48 \\
\hline Mass of Pycnometer+Soil+Water, g & 719.89 \\
\hline Test Temperature, C & 22.1 \\
\hline Density of Water at Test Temp, g/ml & 0.99775 \\
\hline Temperature Coefficient, K & 0.99954 \\
\hline
\end{tabular}

\section{Calculations}

\begin{tabular}{|l|c|}
\hline Mass of Pycnomter and Water at Test Temperature, g & 672.33 \\
\hline Specific Gravity at Test Temperature & 2.42 \\
\hline Specific Gravity at 20 Degrees C & 2.42 \\
\hline
\end{tabular}

\begin{tabular}{|l|c|}
\hline Tare I.D. & 2 \\
\hline Tare Mass, g & 956.56 \\
\hline Dry Mass + Tare, g & 1037.59 \\
\hline Mass of Oven Dry Solids, g & 81.03 \\
\hline
\end{tabular}

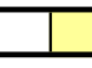

Checked By:




\section{SPECIFIC GRAVITY}

Test performed in accordance to ASTM D854

\begin{tabular}{|l|l|l|l|}
\hline Job \#: & & Job Name: & \\
\hline Lab Job \#: & & Client: & \\
\hline
\end{tabular}

\begin{tabular}{|l|l|l|l|l|}
\hline Boring \#: & \multicolumn{1}{|l|}{} & Sample \#: & & Depth (ft): \\
\hline Soil Description: & Compost-Wood & \\
\hline
\end{tabular}

Initial Moisture Content (Moist Method)

\begin{tabular}{|l|l|}
\hline Tare I.D. & Compost - Wood \\
\hline Tare Mass, g & \\
\hline Wet Mass + Tare, g & \\
\hline Dry Mass + Tare, g & \\
\hline$\%$ Moisture & \#DIV/0! \\
\hline
\end{tabular}

\begin{tabular}{|c|c|c|}
\hline Soil Type & $\begin{array}{c}\text { Moist Mass, g with 250ml } \\
\text { Pycnometer }\end{array}$ & $\begin{array}{c}\text { Moist Mass, g, with } 500 \mathrm{ml} \\
\text { Pycnometer }\end{array}$ \\
\hline $\begin{array}{c}\text { SP, SP- } \\
\text { SM }\end{array}$ & \#DIV/0! & \#DIV/0! \\
\hline SP-SC, & \#DIV/0! & \#DIV/0! \\
SM, SC & \#DIV/0! & \#DIV/0! \\
\hline Silt or Clay & Hon & \\
\hline
\end{tabular}

Note: Values in above table are generated from the reported \%M and guidance from Table 2 of ASTM D854-06

\section{Pycnomter and Test Data}

\begin{tabular}{|l|c|}
\hline Pycnometer I.D. & 3 \\
\hline Calibrated Volume of Pycnometer, ml & 499.12 \\
\hline Average Calibrated Mass of Dry Pycnomter, g & 184.86 \\
\hline Mass of Pycnometer+Soil+Water, g & 696.76 \\
\hline Test Temperature, C & 22.9 \\
\hline Density of Water at Test Temp, g/ml & 0.99756 \\
\hline Temperature Coefficient, $\mathrm{K}$ & 0.99936 \\
\hline
\end{tabular}

\section{Calculations}

\begin{tabular}{|l|c|}
\hline Mass of Pycnomter and Water at Test Temperature, g & 682.76 \\
\hline Specific Gravity at Test Temperature & 1.83 \\
\hline Specific Gravity at 20 Degrees C & 1.83 \\
\hline
\end{tabular}

\section{After Test Data}

\begin{tabular}{|l|c|}
\hline Tare I.D. & 11 \\
\hline Tare Mass, g & 723.26 \\
\hline Dry Mass + Tare, g & 754.03 \\
\hline Mass of Oven Dry Solids, g & 30.77 \\
\hline
\end{tabular}

\begin{tabular}{|l|l|l|l|l}
\hline Tested By: & Nathan Hanson & Date: & & Checked By:
\end{tabular}




\section{SPECIFIC GRAVITY}

Test performed in accordance to ASTM D854

\begin{tabular}{|l|l|l|l|}
\hline Job \#: & & Job Name: & \\
\hline Lab Job \#: & & Client: & \\
\hline
\end{tabular}

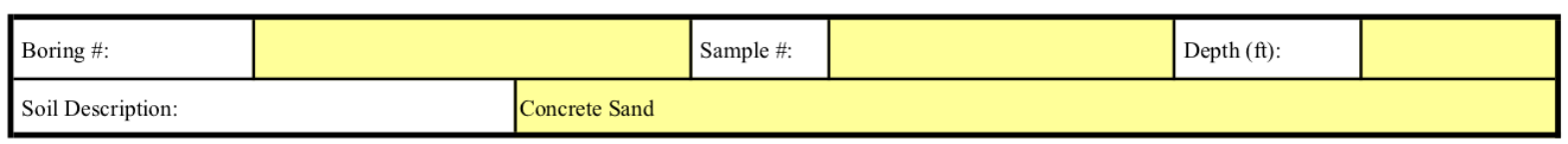

\section{Initial Moisture Content}

(Moist Method)

\begin{tabular}{|l|c|}
\hline Tare I.D. & Concrete Sand \\
\hline Tare Mass, g & \\
\hline Wet Mass + Tare, g & \\
\hline Dry Mass + Tare, g & \\
\hline$\%$ Moisture & \#DIV/0! \\
\hline
\end{tabular}

\begin{tabular}{|c|c|c|}
\hline Soil Type & $\begin{array}{c}\text { Moist Mass, g with 250ml } \\
\text { Pycnometer }\end{array}$ & $\begin{array}{c}\text { Moist Mass, g, with } 500 \mathrm{ml} \\
\text { Pycnometer }\end{array}$ \\
\hline $\begin{array}{c}\text { SP, SP- } \\
\text { SM }\end{array}$ & \#DIV/0! & \#DIV/0! \\
\hline SP-SC, & \#DIV/0! & \#DIV/O! \\
SM, SC & \#DIV/0! & \#DIV/0! \\
\hline Silt or Clay &
\end{tabular}

Note: Values in above table are generated from the reported \%M and guidance from Table 2 of ASTM D854-06

Pycnomter and Test Data
\begin{tabular}{|l|c|}
\hline Pycnometer I.D. & 4 \\
\hline Calibrated Volume of Pycnometer, $\mathrm{ml}$ & 499.14 \\
\hline Average Calibrated Mass of Dry Pycnomter, g & 185.61 \\
\hline Mass of Pycnometer+Soil+Water, g & 766.88 \\
\hline Test Temperature, C & 22.6 \\
\hline Density of Water at Test Temp, g/ml & 0.99764 \\
\hline Temperature Coefficient, $\mathrm{K}$ & 0.99943 \\
\hline
\end{tabular}

After Test Data
\begin{tabular}{|l|c|}
\hline Tare I.D. & 12 \\
\hline Tare Mass, g & 694.45 \\
\hline Dry Mass + Tare, g & 827.45 \\
\hline Mass of Oven Dry Solids, g & 133.00 \\
\hline
\end{tabular}

\section{Calculations}

\begin{tabular}{|l|c|}
\hline Mass of Pycnomter and Water at Test Temperature, g & 683.57 \\
\hline Specific Gravity at Test Temperature & 2.68 \\
\hline Specific Gravity at 20 Degrees C & 2.67 \\
\hline
\end{tabular}




\section{Appendix B: Mechanical Sieve Analysis Results}

\begin{tabular}{|c|c|c|c|c|c|c|}
\hline $\begin{array}{l}\text { DEPARTMEN } \\
\text { Mechnical Siev } \\
\text { Test Method: A }\end{array}$ & $\begin{array}{l}\text { OF CIVIL } \\
\text { halysis } \\
\text { M D6913, D }\end{array}$ & ID ENVIRONMEN] & L ENGINEE & RING & & \\
\hline \multicolumn{2}{|l|}{ Project Name } & \multicolumn{2}{|l|}{ Bioretention Soil } & Project No. & \multicolumn{2}{|l|}{1} \\
\hline \multicolumn{2}{|l|}{ Tested By } & \multicolumn{2}{|l|}{ Nathan Hanson } & Testing Date & $5 / 10 / 17$ & \\
\hline \multicolumn{7}{|c|}{ SPECIMEN ID AND CLASSIFICATION } \\
\hline \multicolumn{2}{|l|}{ Boring No. } & NA & Sample No. & NA & Depth (ft) & NA \\
\hline \multicolumn{2}{|c|}{ Soil Description } & \multicolumn{5}{|c|}{ Top Soil- Wood and Floating Fines } \\
\hline \multicolumn{7}{|c|}{ SIEVE MEASUREMENTS } \\
\hline Dish ID & B54 & \multicolumn{2}{|l|}{ Moist Soil + Dish (g) } & & Water Content & \\
\hline Dish Mass (g) & 100.00 & \multicolumn{2}{|l|}{ Dry Soil + Dish (g) } & 122.36 & Dry Post-Wash (g) & 22.36 \\
\hline Sieve No. & Size, $\mathrm{mm}$ & Mass Retained (g) & \multicolumn{2}{|c|}{ Cumulative Retained (g) } & $\%$ Retained & $\%$ Passing \\
\hline No. 4 & 4.75 & 0.38 & \multicolumn{2}{|c|}{0.38} & $1.7 \%$ & $98.3 \%$ \\
\hline No. 10 & 2.00 & 2.07 & \multicolumn{2}{|l|}{2.45} & $11.0 \%$ & $89.0 \%$ \\
\hline No. 20 & 0.85 & 8.80 & \multicolumn{2}{|c|}{11.25} & $50.3 \%$ & $49.7 \%$ \\
\hline No. 40 & 0.425 & 5.90 & \multicolumn{2}{|c|}{17.15} & $76.7 \%$ & $23.3 \%$ \\
\hline No. 60 & 0.250 & 3.03 & \multicolumn{2}{|c|}{20.18} & $90.3 \%$ & $9.7 \%$ \\
\hline No. 100 & 0.150 & 1.86 & \multicolumn{2}{|c|}{22.04} & $98.6 \%$ & $1.4 \%$ \\
\hline No. 200 & 0.075 & 1.74 & \multicolumn{2}{|c|}{23.78} & $106.4 \%$ & $-6.4 \%$ \\
\hline Pan & -- & 0.63 & \multicolumn{2}{|c|}{24.41} & Sieve Continuity & $91.6 \%$ \\
\hline
\end{tabular}

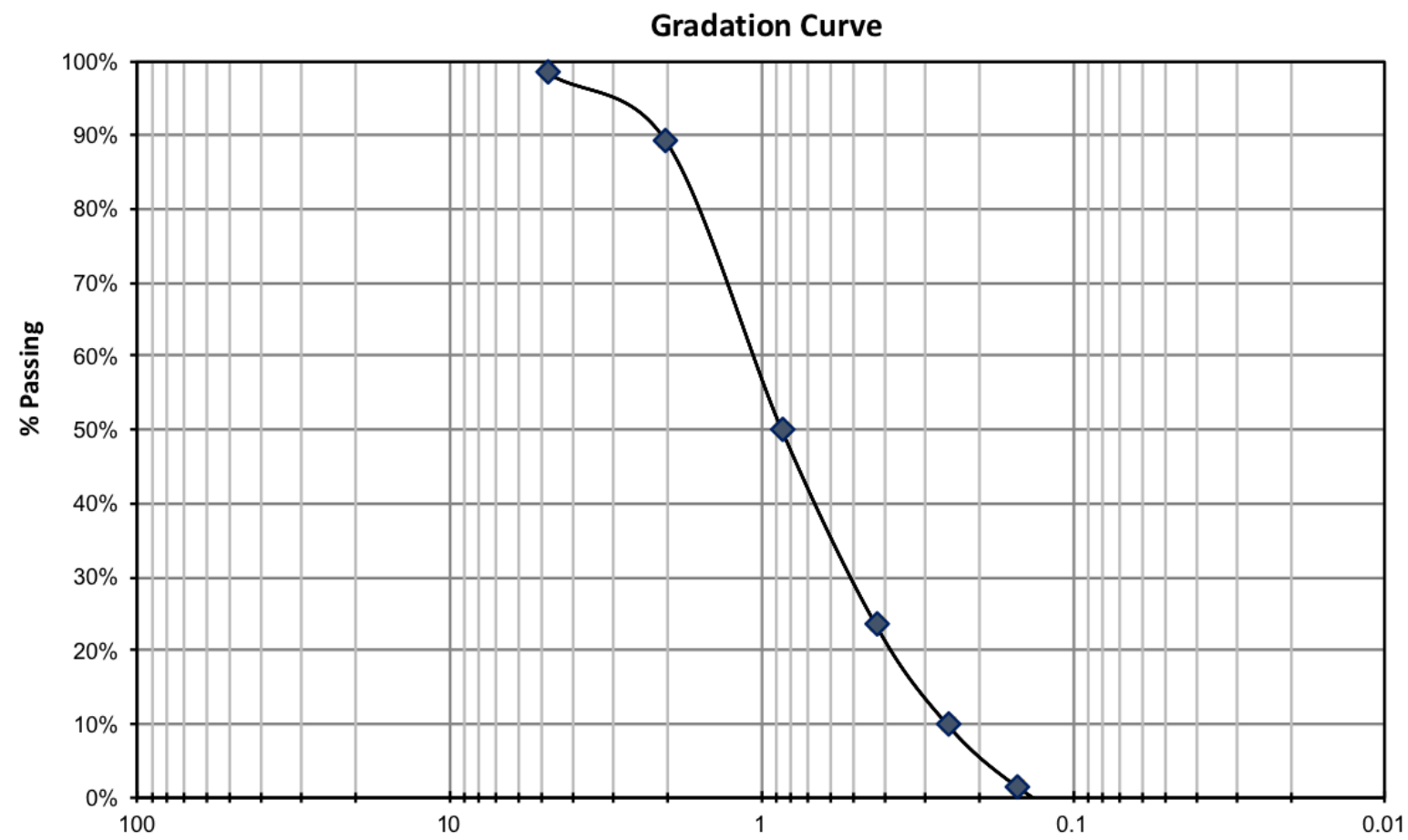




\section{DEPARTMENT OF CIVIL AND ENVIRONMENTAL ENGINEERING}

Mechnical Sieve Analysis

Test Method: ASTM D6913, D2487

\begin{tabular}{|c|c|c|c|c|c|c|}
\hline \multicolumn{2}{|l|}{ Project Name } & \multicolumn{2}{|l|}{ Bioretention Soil } & Project No. & \multicolumn{2}{|l|}{1} \\
\hline \multicolumn{2}{|l|}{ Tested By } & \multicolumn{2}{|l|}{ Nathan Hanson } & Testing Date & \multicolumn{2}{|l|}{$5 / 10 / 17$} \\
\hline \multicolumn{7}{|c|}{ SPECIMEN ID AND CLASSIFICATION } \\
\hline \multicolumn{2}{|l|}{ Boring No. } & \begin{tabular}{l|l}
$N A$ &
\end{tabular} & Sample No. & NA & Depth (ft) & NA \\
\hline Soil Description & & \multicolumn{5}{|l|}{ Top Soil } \\
\hline \multicolumn{7}{|c|}{ "SIEVE MEASUREMENTS } \\
\hline Dish ID & B54 & \multicolumn{2}{|l|}{ Moist Soil + Dish (g) } & 330.45 & Water Content & $240.3 \%$ \\
\hline Dish Mass (g) & 117.13 & \multicolumn{2}{|l|}{ Dry Soil + Dish (g) } & 179.82 & Dry Post-Wash (g) & 62.69 \\
\hline
\end{tabular}

\begin{tabular}{||l|l|c|c|c|c||}
\hline Sieve No. & Size, $\mathrm{mm}$ & Mass Retained (g) & Cumulative Retained $(\mathrm{g})$ & \% Retained & $\%$ Passing \\
\hline No. 4 & 4.75 & 1.85 & 1.85 & $3.0 \%$ & $97.0 \%$ \\
\hline No. 10 & 2.00 & 6.80 & 8.65 & $13.8 \%$ & $86.2 \%$ \\
\hline No. 20 & 0.85 & 6.82 & 15.47 & $24.7 \%$ & $75.3 \%$ \\
\hline No. 40 & 0.425 & 10.33 & 25.80 & $41.2 \%$ & $58.8 \%$ \\
\hline No. 60 & 0.250 & 11.50 & 37.30 & $59.5 \%$ & $40.5 \%$ \\
\hline No. 100 & 0.150 & 11.91 & 49.21 & $78.5 \%$ & $21.5 \%$ \\
\hline No. 200 & 0.075 & 13.75 & 62.96 & $100.4 \%$ & $-0.4 \%$ \\
\hline Pan & -- & 0.81 & 63.77 & Sieve Continuity & $98.3 \%$ \\
\hline
\end{tabular}

Gradation Curve

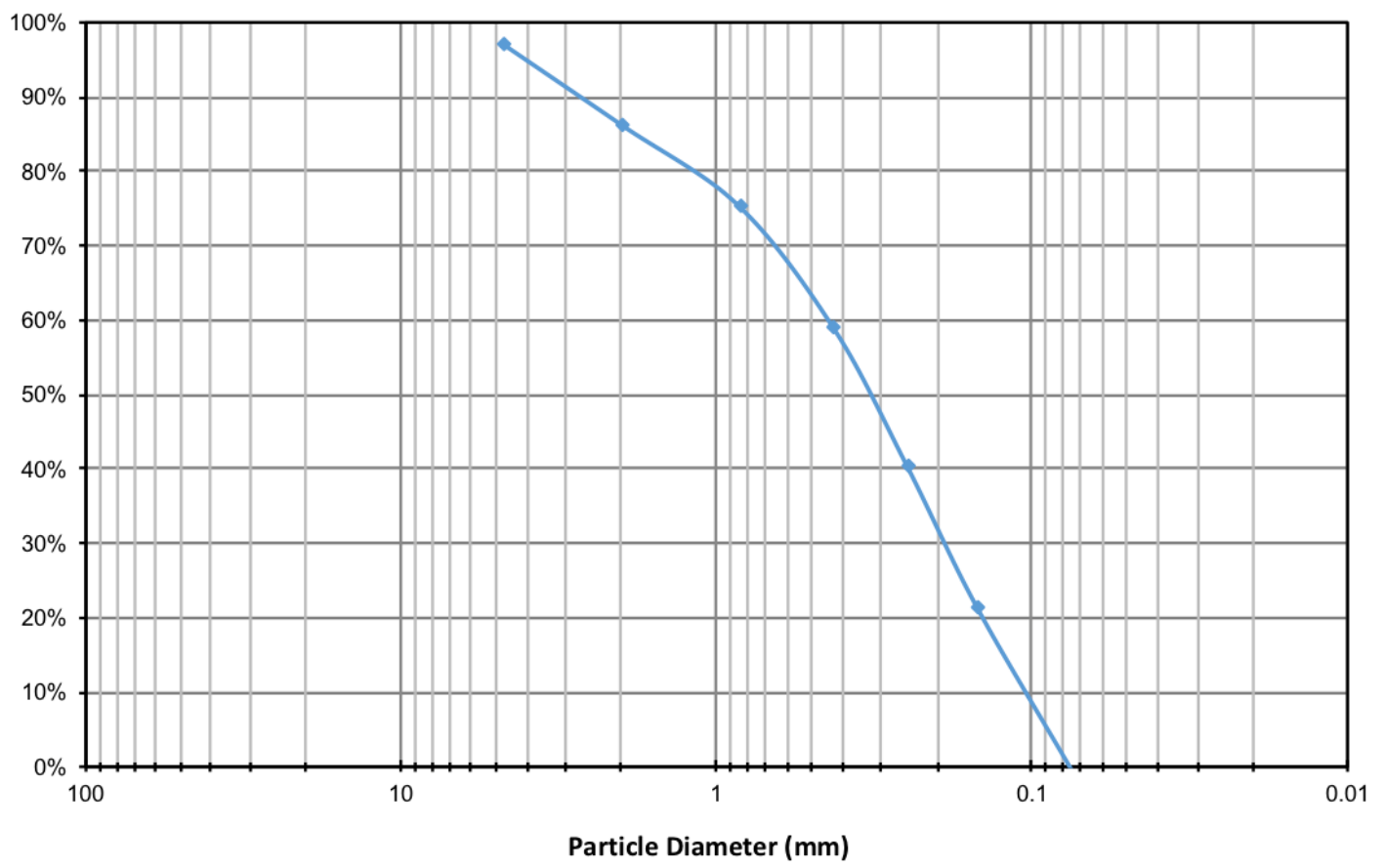


DEPARTMENT OF CIVIL AND ENVIRONMENTAL ENGINEERING

Mechnical Sieve Analysis

Test Method: ASTM D6913, D2487

\begin{tabular}{|c|c|c|c|c|c|c|}
\hline \multicolumn{2}{|l|}{ Project Name } & \multicolumn{2}{|l|}{ Bioretention Soil } & Project No. & \multicolumn{2}{|l|}{1} \\
\hline \multicolumn{2}{|l|}{ Tested By } & \multicolumn{2}{|l|}{ Nathan Hanson } & Testing Date & \multicolumn{2}{|l|}{$5 / 10 / 17$} \\
\hline \multicolumn{7}{|c|}{ SPECIMEN ID AND CLASSIFICATION } \\
\hline \multicolumn{2}{|l|}{ Boring No. } & NA & Sample No. & NA & Depth (ft) & NA \\
\hline Soil Description & & \multicolumn{5}{|l|}{ Concrete Sand } \\
\hline \multicolumn{7}{|c|}{ SIEVE MEASUREMENTS } \\
\hline Dish ID & B54 & Moist Soil + Dish (g) & & 327.93 & Water Content & $54.1 \%$ \\
\hline Dish Mass (g) & 124.90 & Dry Soil + Dish (g) & & 256.62 & Dry Post-Wash (g) & 188.74 \\
\hline
\end{tabular}

\begin{tabular}{||l|l|c|c|c|c||}
\hline \multicolumn{1}{|c|}{ Sieve No. } & Size, $\mathrm{mm}$ & Mass Retained (g) & Cumulative Retained (g) & $\%$ Retained & \% Passing \\
\hline No. 4 & 4.75 & 3.16 & 3.16 & $1.7 \%$ & $98.3 \%$ \\
\hline No. 10 & 2.00 & 30.15 & 33.31 & $17.6 \%$ & $82.4 \%$ \\
\hline No. 20 & 0.85 & 37.55 & 70.86 & $37.5 \%$ & $62.5 \%$ \\
\hline No. 40 & 0.425 & 53.58 & 124.44 & $65.9 \%$ & $34.1 \%$ \\
\hline No. 60 & 0.250 & 37.83 & 162.27 & $86.0 \%$ & $14.0 \%$ \\
\hline No. 100 & 0.150 & 19.19 & 181.46 & $96.1 \%$ & $3.9 \%$ \\
\hline No. 200 & 0.075 & 6.73 & 188.19 & $9.7 \%$ & $0.3 \%$ \\
\hline Pan & -- & 0.42 & 188.61 & Sieve Continuity & $100.1 \%$ \\
\hline
\end{tabular}

Gradation Curve

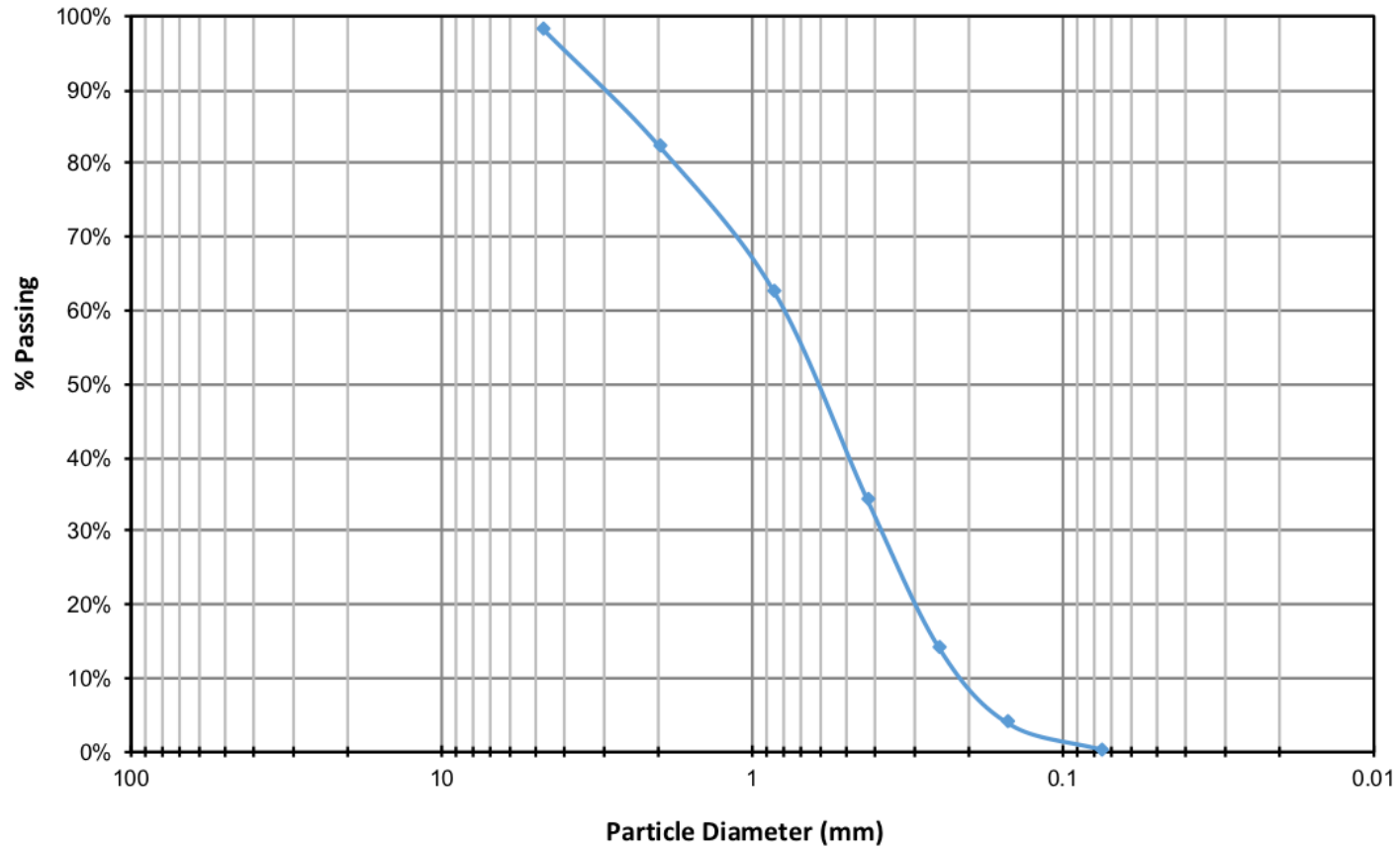




\section{DEPARTMENT OF CIVIL AND ENVIRONMENTAL ENGINEERING}

Mechnical Sieve Analysis

Test Method: ASTM D6913, D2487

\begin{tabular}{|c|c|c|c|c|c|c|}
\hline \multicolumn{2}{|l|}{ Project Name } & \multicolumn{2}{|l|}{ Bioretention Soil } & Project No. & \multicolumn{2}{|l|}{1} \\
\hline \multicolumn{2}{|l|}{ Tested By } & \multicolumn{2}{|l|}{ Nathan Hanson } & Testing Date & \multicolumn{2}{|l|}{$5 / 10 / 17$} \\
\hline \multicolumn{7}{|c|}{ SPECIMEN ID AND CLASSIFICATION } \\
\hline \multicolumn{2}{|l|}{ Boring No. } & NA & Sample No. & NA & Depth (ft) & NA \\
\hline Soil Description & & \multicolumn{5}{|l|}{ Compost } \\
\hline \multicolumn{7}{|c|}{ SIEVE MEASUREMENTS } \\
\hline Dish ID & $\mathrm{B} 60$ & \multicolumn{2}{|c|}{ Moist Soil + Dish (g) } & 331.21 & Water Content & $43.4 \%$ \\
\hline Dish Mass (g) & 119.27 & \multicolumn{2}{|l|}{ Dry Soil + Dish (g) } & 267.02 & Dry Post-Wash (g) & 90.21 \\
\hline
\end{tabular}

\begin{tabular}{||l|l|c|c|c|c||}
\hline Sieve No. & Size, $\mathrm{mm}$ & Mass Retained (g) & Cumulative Retained (g) & \% Retained & $\%$ Passing \\
\hline No. 4 & 4.75 & 2.21 & 2.21 & $2.4 \%$ & $97.6 \%$ \\
\hline No. 10 & 2.00 & 6.10 & 8.31 & $9.2 \%$ & $90.8 \%$ \\
\hline No. 20 & 0.85 & 12.16 & 20.47 & $22.7 \%$ & $77.3 \%$ \\
\hline No. 40 & 0.425 & 19.56 & 40.03 & $44.4 \%$ & $55.6 \%$ \\
\hline No. 60 & 0.250 & 23.24 & 63.27 & $70.1 \%$ & $29.9 \%$ \\
\hline No. 100 & 0.150 & 18.55 & 81.82 & $90.7 \%$ & $9.3 \%$ \\
\hline No. 200 & 0.075 & 8.19 & 90.01 & $99.8 \%$ & $0.2 \%$ \\
\hline Pan & -- & 0.74 & 90.75 & Sieve Continuity & $99.4 \%$ \\
\hline \hline
\end{tabular}

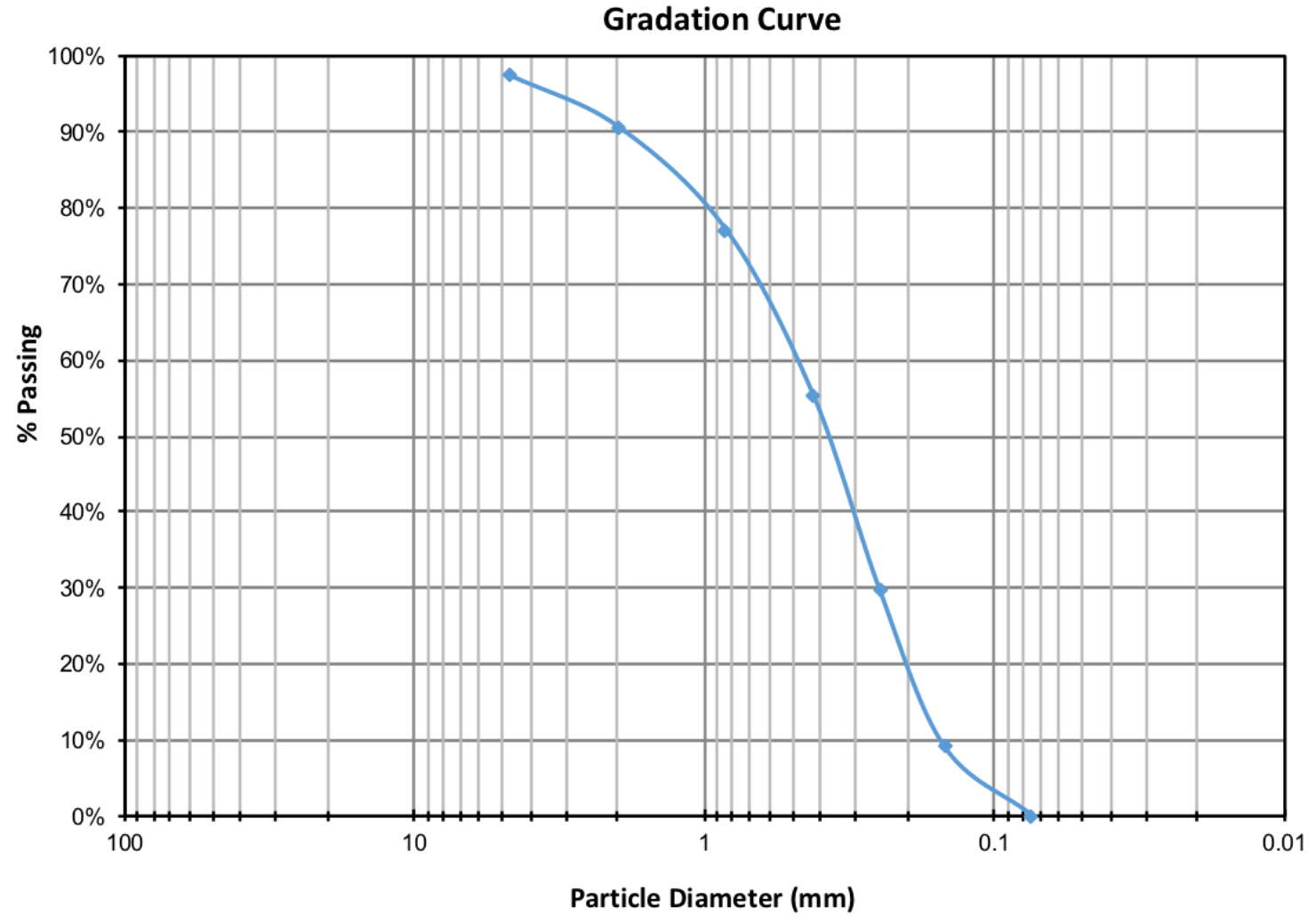




\section{DEPARTMENT OF CIVIL AND ENVIRONMENTAL ENGINEERING}

Mechnical Sieve Analysis

Test Method: ASTM D6913, D2487

\begin{tabular}{|l|l|l|l|}
\hline \hline Project Name & Bioretention Soil & Project No. & 1 \\
\hline Tested By & Nathan Hanson & Testing Date & $5 / 10 / 17$ \\
\hline
\end{tabular}

\begin{tabular}{||l|l|l|l|l|l||}
\hline \multicolumn{7}{|c||}{ SPECIMEN ID AND CLASSIFICATION } \\
\hline Boring No. & NA & Sample No. NA & Depth (ft) & NA \\
\hline Soil Description & \multicolumn{4}{|l||}{ Compost - Wood and Floating Fines } \\
\hline
\end{tabular}

\begin{tabular}{||l|l|l|l|l|c||}
\hline \multicolumn{7}{|c||}{ SIEVE MEASUREMENTS } \\
\hline Dish ID & B60 & Moist Soil + Dish (g) & & Water Content & \\
\hline Dish Mass (g) & 100.00 & Dry Soil + Dish (g) & & Dry Post-Wash (g) & 38.25 \\
\hline
\end{tabular}

\begin{tabular}{||l|l|c|c|c|c||}
\hline \hline Sieve No. & Size, $\mathrm{mm}$ & Mass Retained (g) & Cumulative Retained $(\mathrm{g})$ & \% Retained & $\%$ Passing \\
\hline No. 4 & 4.75 & 1.44 & 1.44 & $3.8 \%$ & $96.2 \%$ \\
\hline No. 10 & 2.00 & 2.91 & 4.35 & $11.4 \%$ & $88.6 \%$ \\
\hline No. 20 & 0.85 & 4.30 & 8.65 & $22.6 \%$ & $77.4 \%$ \\
\hline No. 40 & 0.425 & 3.63 & 12.28 & $32.1 \%$ & $67.9 \%$ \\
\hline No. 60 & 0.250 & 3.40 & 15.68 & $41.0 \%$ & $59.0 \%$ \\
\hline No. 100 & 0.150 & 7.00 & 22.68 & $59.3 \%$ & $40.7 \%$ \\
\hline No. 200 & 0.075 & 12.69 & 35.37 & $92.5 \%$ & $7.5 \%$ \\
\hline Pan & -- & 3.83 & 39.20 & Sieve Continuity & $97.6 \%$ \\
\hline
\end{tabular}

\section{Gradation Curve}

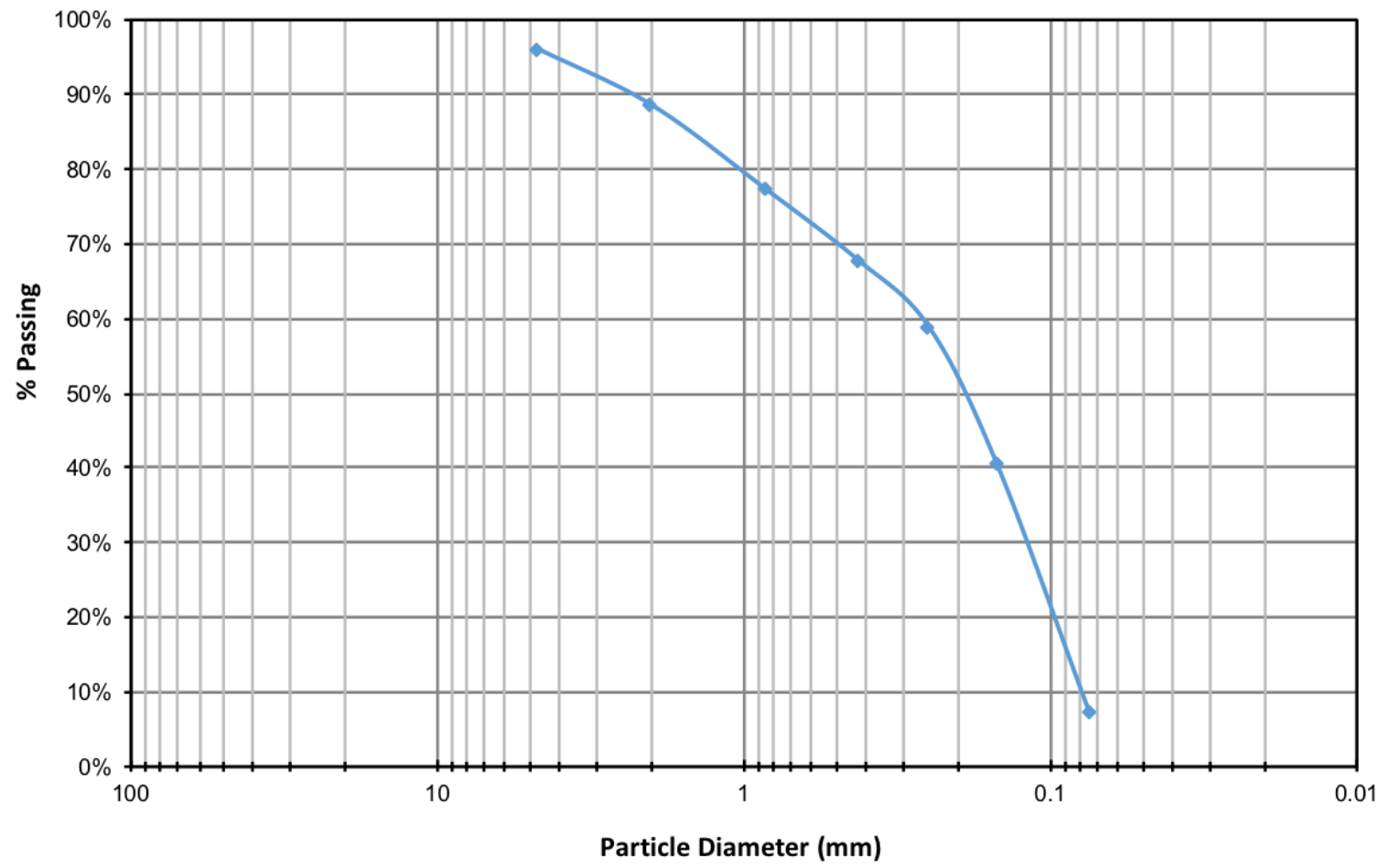




\begin{tabular}{|c|c|c|c|c|c|}
\hline $\begin{array}{c}\text { Percent of Top Soil } \\
72.3 \% \\
72.31798594\end{array}$ & $\begin{array}{c}\text { Percent floating Particles } \\
27.7 \% \\
27.68201406\end{array}$ & & & Dry Post Wash Mass & 88.18 \\
\hline Sieve No. & Size, $\mathrm{mm}$ & Mass Retained (g) & Cumulative Retained (g) & $\%$ Retained & $\%$ Passing \\
\hline No. 4 & 4.75 & 2.23 & 2.23 & $2.5 \%$ & $97.5 \%$ \\
\hline No. 10 & 2.00 & 8.87 & 11.10 & $12.6 \%$ & $87.4 \%$ \\
\hline No. 20 & 0.85 & 15.62 & 26.72 & $30.3 \%$ & $69.7 \%$ \\
\hline No. 40 & 0.425 & 16.23 & 42.95 & $48.7 \%$ & $51.3 \%$ \\
\hline No. 60 & 0.250 & 14.53 & 57.48 & $65.2 \%$ & $34.8 \%$ \\
\hline No. 100 & 0.150 & 13.77 & 71.25 & $80.8 \%$ & $19.2 \%$ \\
\hline No. 200 & 0.075 & 15.49 & 86.74 & $98.4 \%$ & $1.6 \%$ \\
\hline Pan & -- & 1.44 & 88.18 & Sieve Continuity & $100.0 \%$ \\
\hline
\end{tabular}

\begin{tabular}{|c|c|c|c|c|c|}
\hline $\begin{array}{c}\text { Percent of Top Soil } \\
70.2 \% \\
70.2241943\end{array}$ & $\begin{array}{c}\text { Percent floating Particles } \\
29.8 \% \\
29.7758057\end{array}$ & & & Dry Post-Wash (g) & 128.46 \\
\hline Sieve No. & Size, $\mathrm{mm}$ & Mass Retained $(\mathrm{g})$ & Cumulative Retained (g) & $\%$ Retained & $\%$ Passing \\
\hline No. 4 & 4.75 & \begin{tabular}{|l|}
3.65 \\
\end{tabular} & 3.65 & $2.8 \%$ & $97.2 \%$ \\
\hline No. 10 & 2.00 & 9.01 & 12.66 & $9.9 \%$ & $90.1 \%$ \\
\hline No. 20 & 0.85 & 16.46 & 29.12 & $22.7 \%$ & $77.3 \%$ \\
\hline No. 40 & 0.425 & 23.19 & 52.31 & $40.7 \%$ & $59.3 \%$ \\
\hline No. 60 & 0.250 & 26.64 & 78.95 & $61.5 \%$ & $38.5 \%$ \\
\hline No. 100 & 0.150 & 25.55 & 104.50 & $81.3 \%$ & $18.7 \%$ \\
\hline No. 200 & 0.075 & 20.88 & 125.38 & $97.6 \%$ & $2.4 \%$ \\
\hline Pan & -- & 4.57 & 129.95 & Sieve Continuity & $98.9 \%$ \\
\hline
\end{tabular}




\begin{tabular}{|c|c|c|c|c|c|}
\hline \multicolumn{6}{|c|}{$80 \%$ Sand, $20 \%$ Comp } \\
\hline Sieve No. & Percent Passing by Mass & $\%$ Compost & $\%$ Sand & $\%$ Top Soil & $\%$ Passing by Volume \\
\hline No. 4 & $\begin{array}{ll}98.09 \%\end{array}$ & 21.13303737 & 71.47614532 & 92.6091827 & $92.61 \%$ \\
\hline No. 10 & $83.91 \%$ & 20.46220063 & 64.42062811 & 84.88282874 & $84.88 \%$ \\
\hline No. 20 & $65.43 \%$ & 17.3268537 & 49.58477907 & 66.91163277 & $66.91 \%$ \\
\hline No. 40 & $39.11 \%$ & 13.28823941 & 29.65208935 & 42.94032876 & $42.94 \%$ \\
\hline No. 60 & $18.93 \%$ & 8.476447745 & 14.07960889 & 22.55605663 & $22.56 \%$ \\
\hline No. 100 & $6.82 \%$ & 3.995001649 & 4.937775505 & 8.932777154 & $8.93 \%$ \\
\hline No. 200 & $0.71 \%$ & 0.49828596 & 0.500924576 & 0.999210536 & $1.00 \%$ \\
\hline Pan & $99.83 \%$ & & & & \\
\hline
\end{tabular}

\begin{tabular}{|lrlrrr|}
\hline \multicolumn{5}{|c|}{$60 \%$ Sand, $40 \%$ Comp } & \\
\hline Sieve No. & Percent Passing by Mass & $\%$ Compost & $\%$ Sand & \% Top Soil & $\%$ Passing by Volume \\
\hline \hline No. 4 & $97.86 \%$ & 42.16549942 & 53.47954682 & 95.64504624 & $95.65 \%$ \\
No. 10 & $85.47 \%$ & 38.80154578 & 49.21296114 & 88.01450692 & $88.01 \%$ \\
No. 20 & $68.41 \%$ & 30.65419701 & 38.87947698 & 69.53367399 & $69.53 \%$ \\
No. 40 & $44.15 \%$ & 19.79477388 & 25.10620177 & 44.90097565 & $44.90 \%$ \\
No. 60 & $23.83 \%$ & 10.48250788 & 13.29522426 & 23.77773215 & $23.78 \%$ \\
No. 100 & $9.77 \%$ & 4.187396359 & 5.31097847 & 9.498374829 & $9.50 \%$ \\
No. 200 & $1.13 \%$ & 0.471302228 & 0.597764283 & 1.069066511 & $1.07 \%$ \\
\hline
\end{tabular}

$70 \%$ Sand, $10 \%$ Compost, $20 \%$ Top Soil

\begin{tabular}{lrrrrr}
\hline Sieve No. & Percent Passing by Mass & \% Compost & \% Sand & \% Top Soil & \% Passing by Volume \\
\hline \hline No. 4 & $98.04 \%$ & 10.5809049 & 62.62677699 & 19.49293434 & $92.70 \%$ \\
No. 10 & $84.14 \%$ & 8.341651493 & 49.37297449 & 15.36761424 & $73.08 \%$ \\
No. 20 & $65.39 \%$ & 6.343270182 & 37.54485753 & 11.68604673 & $55.57 \%$ \\
No. 40 & $40.03 \%$ & 4.002441965 & 23.68984909 & 7.373597922 & $35.07 \%$ \\
No. 60 & $20.63 \%$ & 2.057694545 & 12.17918303 & 3.790838782 & $18.03 \%$ \\
No. 100 & $8.41 \%$ & 0.827157316 & 4.89581914 & 1.523851068 & $7.25 \%$ \\
No. 200 & $0.77 \%$ & 0.075405478 & 0.446313628 & 0.138917611 & $0.66 \%$ \\
\hline
\end{tabular}

$65 \%$ Sand, $15 \%$ Compost, $20 \%$ Top Soil

\begin{tabular}{lrrrrr}
\hline \multicolumn{1}{c}{ Sieve No. } & Percent Passing \% Compost & \% Sand & \% Top Soil & \% Passing by Volume \\
\hline \hline No. 4 & $97.96 \%$ & 21.14584183 & 58.10955519 & 14.60866923 & $93.86 \%$ \\
No. 10 & $84.67 \%$ & 16.78765523 & 46.13309728 & 11.59780274 & $74.52 \%$ \\
No. 20 & $66.52 \%$ & 12.90487859 & 35.46308351 & 8.915374675 & $57.28 \%$ \\
No. 40 & $41.69 \%$ & 8.336778328 & 22.90977509 & 5.759488698 & $37.01 \%$ \\
No. 60 & $22.05 \%$ & 4.397029541 & 12.08319976 & 3.03770125 & $19.52 \%$ \\
No. 100 & $9.12 \%$ & 1.794521226 & 4.931410681 & 1.239750454 & $7.97 \%$ \\
No. 200 & $0.91 \%$ & 0.178911977 & 0.491656728 & 0.123601884 & $0.79 \%$ \\
& & & & & \\
\hline
\end{tabular}

\begin{tabular}{|lrlrrr}
\hline \multicolumn{6}{|c}{$50 \%$ Sand, 30\% Compost, 20\% Top Soil } \\
\hline \hline Sieve No. & Percent Passing \% Compost & \multicolumn{1}{c}{ \% Sand } & \% Top Soil & \% Passing by Volume \\
\hline \hline No. 4 & $97.80 \%$ & 31.66713874 & 44.62690673 & 19.44652377 & $95.74 \%$ \\
No. 10 & $85.70 \%$ & 25.48852249 & 35.91969345 & 15.65228746 & $77.06 \%$ \\
No. 20 & $68.37 \%$ & 19.89557651 & 28.03783583 & 12.21770633 & $60.15 \%$ \\
No. 40 & $45.08 \%$ & 13.51962756 & 19.0525315 & 8.302289668 & $40.87 \%$ \\
No. 60 & $25.54 \%$ & 7.639986604 & 10.76664906 & 4.691651567 & $23.10 \%$ \\
No. 100 & $11.36 \%$ & 3.355048355 & 4.72810099 & 2.060306999 & $10.14 \%$ \\
No. 200 & $1.19 \%$ & 0.349916516 & 0.493119755 & 0.214880792 & $1.06 \%$ \\
\hline
\end{tabular}


Appendix C: Influent Total Suspended Solids Results

This Page is intentionally left blank 
Influent Total Suspended Solids Worksheet

\begin{tabular}{|c|c|c|c|c|c|c|c|}
\hline $\begin{array}{c}\text { Column ID (\% Sand of } \\
\text { Column) }\end{array}$ & Tin ID & Mass of Tin (g) & $\begin{array}{l}\text { Mass of Clean } \\
\text { Filter +Tin (g) }\end{array}$ & $\begin{array}{c}\text { Volume of Stormwater } \\
\text { Permeate }(\mathrm{mL})\end{array}$ & $\begin{array}{c}\text { Mass of Filter + Tin } \\
\text { After Drying (g) }\end{array}$ & $\begin{array}{c}\text { Concentration of TSS in } \\
\text { Permeate }(\mathrm{mg} / \mathrm{L})\end{array}$ & $\begin{array}{c}\text { Pore Volume } \\
\text { Number }\end{array}$ \\
\hline INF & 18 & & 1.0287 & 50 & 1.1084 & \begin{tabular}{|l|}
1594 \\
\end{tabular} & 3 \\
\hline INF & 75 & & 1.0305 & 50 & 1.1055 & 1500 & 3 \\
\hline 60 & 89 & & 1.0299 & 50 & 1.0314 & 30 & 2 \\
\hline 60 & 84 & & 1.0302 & 50 & 1.0319 & 34 & 2 \\
\hline 60 & 72 & & 1.038 & 50 & 1.0391 & 22 & 3 \\
\hline 60 & 76 & & 1.0335 & 50 & 1.0348 & 26 & 3 \\
\hline 70 & 26 & & 1.0183 & 50 & 1.0189 & 12 & 3 \\
\hline 70 & 67 & & 1.0291 & 50 & 1.0299 & 16 & 3 \\
\hline 80 & 33 & & 1.0277 & 50 & 1.029 & 26 & 2 \\
\hline 80 & 35 & & 1.0179 & 50 & 1.0196 & 34 & 2 \\
\hline 65 & 20 & & 1.0317 & 50 & 1.0352 & 70 & 1 \\
\hline 65 & 161 & & 1.0319 & 50 & 1.0346 & 54 & 1 \\
\hline 60 & 21 & & 1.0342 & 50 & 1.0408 & 132 & 1 \\
\hline 60 & 54 & & 1.03 & 50 & 1.0381 & 162 & 1 \\
\hline 70 & 89 & & 1.0346 & 50 & 1.0377 & 62 & 1 \\
\hline 70 & 43 & & 1.0234 & 50 & 1.0272 & 76 & 1 \\
\hline INF & 64 & & 1.0323 & 50 & 1.1162 & 1678 & 1 \\
\hline INF & 31 & & 1.0256 & 50 & 1.106 & 1608 & 1 \\
\hline INF & 47 & & 1.0368 & 50 & 1.1292 & 1848 & 2 \\
\hline INF & 810 & & 1.0327 & 50 & 1.1301 & 1948 & 2 \\
\hline 70 & 2 & & 1.0247 & 50 & 1.0251 & 8 & 2 \\
\hline 70 & 21 & & 1.0317 & 50 & 1.032 & 6 & 2 \\
\hline 100 & 3 & & 1.0342 & 50 & 1.0385 & 86 & 4 \\
\hline 100 & 32 & & 1.0222 & 50 & 1.0214 & 0 & 4 \\
\hline 100 & 133 & & 1.0253 & 25 & 1.0242 & 0 & 3 \\
\hline 100 & $26 \mathrm{~B}$ & & 1.0307 & 50 & 1.0307 & 0 & 3 \\
\hline 80 & 22 & & 1.027 & 50 & 1.0297 & 54 & 8 \\
\hline 80 & $2 B$ & & 1.0293 & 50 & 1.0325 & 64 & 8 \\
\hline 50 & 34 & & 1.0163 & 50 & 1.0166 & 6 & 2 \\
\hline 50 & 16 & & 1.0251 & 50 & 1.0258 & 14 & 2 \\
\hline 65 & 25 & & 1.0268 & 50 & 1.0276 & 16 & 3 \\
\hline 65 & 67 & & 1.0303 & 50 & 1.0315 & 24 & 3 \\
\hline INF & $26 B$ & & 1.0191 & 50 & 1.1001 & 1620 & 3 \\
\hline INF & $21 B$ & & 1.0317 & 50 & 1.1146 & 1658 & 3 \\
\hline 65 & 10 & & 1.0304 & 50 & 1.0312 & 16 & 2 \\
\hline 65 & 38 & & 1.0361 & 50 & 1.0382 & 42 & 2 \\
\hline 100 & 29 & & 1.0216 & 50 & 1.0203 & 0 & 2 \\
\hline 100 & 162 & & 1.0225 & 50 & 1.0222 & 0 & 2 \\
\hline 60 & 88 & & 1.042 & 50 & 1.0446 & 52 & 7 \\
\hline 60 & & & 1.0305 & 50 & 1.0333 & 56 & 7 \\
\hline
\end{tabular}




\begin{tabular}{|c|c|c|c|c|c|c|}
\hline 80 & & 1.0319 & 50 & 1.0341 & 44 & 6 \\
\hline 80 & & 1.0277 & 50 & 1.0304 & 54 & 6 \\
\hline 80 & & 1.0253 & 50 & 1.0284 & 62 & 7 \\
\hline 80 & & 1.0347 & 50 & 1.0376 & 58 & 7 \\
\hline 70 & & 1.0388 & 50 & 1.0415 & 54 & 7 \\
\hline 70 & & 1.0198 & 50 & 1.0235 & 74 & 7 \\
\hline 70 & & 1.0381 & 50 & 1.0414 & 66 & 8 \\
\hline 70 & & 1.0301 & 50 & 1.0338 & 74 & 8 \\
\hline 70 & & 1.0335 & 50 & 1.0372 & 74 & 9 \\
\hline 70 & & 1.0249 & 50 & & & 9 \\
\hline 80 & & 1.034 & 50 & 1.038 & 80 & 5 \\
\hline 80 & & 1.0337 & 50 & 1.0361 & 48 & 5 \\
\hline 70 & & 1.0392 & 50 & 1.0414 & 44 & 6 \\
\hline 70 & & 1.0357 & 50 & 1.0374 & 34 & 6 \\
\hline 60 & & 1.0355 & 50 & 1.0373 & 36 & 6 \\
\hline 60 & & 1.0204 & 50 & 1.0222 & 36 & 6 \\
\hline 60 & & 1.0267 & 50 & 1.0296 & 58 & 8 \\
\hline 60 & & 1.0281 & 50 & 1.0311 & 60 & 8 \\
\hline 100 & 7 & 1.0379 & 50 & 1.0379 & 0 & 1 \\
\hline 100 & 10 & 1.0334 & 50 & 1.033 & 0 & 1 \\
\hline 60 & 1 & 1.0211 & 50 & 1.0222 & 22 & \\
\hline 60 & 100 & 1.0264 & 50 & 1.0282 & 36 & \\
\hline 60 & 53 & 1.0191 & 50 & 1.0203 & 24 & 4 \\
\hline 60 & 6 & 1.0288 & 50 & 1.0208 & 0 & 4 \\
\hline 80 & 40 & 1.0336 & 50 & 1.0347 & 22 & 3 \\
\hline 80 & 27 & 1.0296 & 50 & 1.0306 & 20 & 3 \\
\hline 70 & 23 & 1.0329 & 50 & 1.0349 & 40 & 5 \\
\hline 70 & 28 & 1.0275 & 50 & 1.0298 & 46 & 5 \\
\hline INF & 49 & 1.0327 & 50 & 1.1181 & 1708 & 4 \\
\hline INF & 5 & 1.023 & 50 & 1.1057 & 1654 & 4 \\
\hline 50 & 48 & 1.0339 & 50 & 1.0461 & 244 & 1 \\
\hline 50 & 271 & 1.0416 & 50 & 1.0534 & 236 & 1 \\
\hline 60 & 107 & 1.0237 & 50 & 1.0254 & 34 & 5 \\
\hline 60 & 42 & 1.0307 & 50 & 1.0325 & 36 & 5 \\
\hline 80 & 50 & 1.0353 & 50 & 1.0364 & 22 & 4 \\
\hline 80 & 56 & 1.0245 & 50 & 1.026 & 30 & 4 \\
\hline 80 & 64 & 1.0316 & 50 & 1.0473 & 314 & 1 \\
\hline 80 & 42 & 1.0307 & 50 & 1.0411 & 208 & 1 \\
\hline
\end{tabular}




\section{Appendix D: Hydraulic Conductivity Results}

Hydraulic Conductivity

\begin{tabular}{|c|c|c|c|c|c|c|c|c|}
\hline Column ID (\% Sand) & Water Head $(\mathrm{cm})$ & Volume (L) & Time to fill (min) & Flow Rate (L/min) & Hydraulic Conductivity (cm/hr) & Hydraulic Conductivity (cm/min) & Seconds & Minutes \\
\hline 50 & 38.1 & 2 & 35.500 & 0.056 & 6.809 & 0.113 & 0.500 & 35 \\
\hline 50 & 38.1 & 2 & 35.633 & 0.056 & 6.783 & 0.113 & 0.133 & 71 \\
\hline 50 & 38.1 & 2 & 36.867 & 0.054 & 6.556 & 0.109 & 0.000 & 108 \\
\hline 50 & 38.1 & 2 & 40.500 & 0.049 & 5.968 & 0.099 & 0.500 & 148 \\
\hline 60 & 38.735 & 2 & 11.133 & 0.180 & 21.585 & 0.360 & & \\
\hline 60 & 38.735 & 2 & 11.017 & 0.182 & 21.814 & 0.364 & & \\
\hline 60 & 38.735 & 2 & 9.333 & 0.214 & 25.748 & 0.429 & 0.333 & 9 \\
\hline 60 & 38.735 & 2 & 9.000 & 0.222 & 26.702 & 0.445 & 0.333 & 18 \\
\hline 60 & 38.735 & 2 & 8.233 & 0.243 & 29.188 & 0.486 & 0.567 & 26 \\
\hline 60 & 38.735 & 2 & 9.033 & 0.221 & 26.603 & 0.443 & 0.600 & 35 \\
\hline 60 & 38.735 & 2 & 9.217 & 0.217 & 26.074 & 0.435 & 0.817 & 44 \\
\hline 60 & 38.735 & 2 & 8.183 & 0.244 & 29.367 & 0.489 & 0.000 & 53 \\
\hline 60 & 38.735 & 2 & 7.200 & 0.278 & 33.377 & 0.556 & 0.200 & 60 \\
\hline 60 & 38.735 & 2 & 9.833 & 0.203 & 24.439 & 0.407 & 0.033 & 70 \\
\hline 65 & 38.1 & 2 & 25.417 & 0.079 & 9.553 & 0.159 & & \\
\hline 65 & 38.1 & 2 & 18.583 & 0.108 & 13.066 & 0.218 & & \\
\hline 65 & 38.1 & 2 & 19.050 & 0.105 & 12.746 & 0.212 & 0.050 & 19 \\
\hline 65 & 38.1 & 2 & 16.633 & 0.120 & 14.598 & 0.243 & 0.683 & 35 \\
\hline 65 & 38.1 & 2 & 17.183 & 0.116 & 14.131 & 0.236 & 0.867 & 52 \\
\hline 65 & 38.1 & 2 & 17.933 & 0.112 & 13.540 & 0.226 & 0.800 & 70 \\
\hline 65 & 38.1 & 2 & 20.700 & 0.097 & 11.730 & 0.195 & 0.500 & 91 \\
\hline 65 & 38.1 & 2 & 17.000 & 0.118 & 14.283 & 0.238 & 0.500 & 108 \\
\hline 65 & 38.1 & 2 & 16.500 & 0.121 & 14.716 & 0.245 & 0.000 & 125 \\
\hline 65 & 38.1 & 2 & 17.000 & 0.118 & 14.283 & 0.238 & 0.000 & 142 \\
\hline 65 & 38.1 & 2 & 19.500 & 0.103 & 12.452 & 0.208 & 0.500 & 161 \\
\hline 70 & 40.64 & 2 & 7.667 & 0.261 & 30.864 & 0.514 & & \\
\hline 70 & 40.64 & 2 & 12.300 & 0.163 & 19.237 & 0.321 & & \\
\hline 70 & 40.64 & 2 & 14.067 & 0.142 & 16.821 & 0.280 & & \\
\hline 70 & 40.64 & 2 & 8.067 & 0.248 & 29.333 & 0.489 & 0.067 & 8 \\
\hline 70 & 40.64 & 2 & 6.167 & 0.324 & 38.371 & 0.640 & 0.233 & 14 \\
\hline 70 & 40.64 & 2 & 6.767 & 0.296 & 34.969 & 0.583 & 0.000 & 21 \\
\hline 70 & 40.64 & 2 & 6.033 & 0.331 & 39.219 & 0.654 & 0.033 & 27 \\
\hline 70 & 40.64 & 2 & 7.383 & 0.271 & 32.048 & 0.534 & 0.417 & 34 \\
\hline 70 & 40.64 & 2 & 6.583 & 0.304 & 35.942 & 0.599 & 0.000 & 41 \\
\hline 70 & 40.64 & 2 & 6.483 & 0.308 & 36.497 & 0.608 & 0.483 & 47 \\
\hline 70 & 40.64 & 2 & 7.667 & 0.261 & 30.864 & 0.514 & 0.150 & 55 \\
\hline 70 & 40.64 & 2 & 6.183 & 0.323 & 38.268 & 0.638 & 0.333 & 61 \\
\hline 70 & 40.64 & 2 & 7.417 & 0.270 & 31.904 & 0.532 & 0.750 & 68 \\
\hline 80 & 41.275 & 2 & 22.383 & 0.089 & 10.374 & 0.173 & & \\
\hline 80 & 41.275 & 2 & 24.333 & 0.082 & 9.543 & 0.159 & & \\
\hline 80 & 41.275 & 2 & 10.533 & 0.190 & 22.045 & 0.367 & 0.533 & 10 \\
\hline 80 & 41.275 & 2 & 6.850 & 0.292 & 33.899 & 0.565 & 0.383 & 17 \\
\hline 80 & 41.275 & 2 & 7.000 & 0.286 & 33.172 & 0.553 & 0.383 & 24 \\
\hline 80 & 41.275 & 2 & 6.767 & 0.296 & 34.316 & 0.572 & 0.150 & 31 \\
\hline 80 & 41.275 & 2 & 7.083 & 0.282 & 32.782 & 0.546 & 0.233 & 38 \\
\hline 80 & 41.275 & 2 & 7.067 & 0.283 & 32.859 & 0.548 & 0.300 & 45 \\
\hline 80 & 41.275 & 2 & 7.733 & 0.259 & 30.027 & 0.500 & 0.033 & 53 \\
\hline 80 & 41.275 & 2 & 8.300 & 0.241 & 27.977 & 0.466 & 0.333 & 61 \\
\hline 80 & 41.275 & 2 & 5.733 & 0.349 & 40.501 & 0.675 & 0.067 & 67 \\
\hline 80 & 41.275 & 2 & 6.967 & 0.287 & 33.331 & 0.556 & 0.033 & 74 \\
\hline 100 & 32.7025 & 2 & 10.083 & 0.198 & 25.742 & 0.429 & & \\
\hline 100 & 32.7025 & 2 & 7.417 & 0.270 & 34.998 & 0.583 & & \\
\hline 100 & 32.7025 & 2 & 7.283 & 0.275 & 35.639 & 0.594 & & \\
\hline 100 & 32.7025 & 2 & 10.083 & 0.198 & 25.742 & 0.429 & & \\
\hline 100 & 32.7025 & 2 & 10.233 & 0.195 & 25.365 & 0.423 & 0.233 & 10 \\
\hline 100 & 32.7025 & 2 & 6.550 & 0.305 & 39.629 & 0.660 & 0.783 & 16 \\
\hline 100 & 32.7025 & 2 & 6.600 & 0.303 & 39.329 & 0.655 & 0.383 & 23 \\
\hline 100 & 32.7025 & 2 & 6.333 & 0.316 & 40.985 & 0.683 & 0.717 & 29 \\
\hline 100 & 32.7025 & 2 & 6.833 & 0.293 & 37.986 & 0.633 & 0.550 & 36 \\
\hline 100 & 32.7025 & 2 & 6.667 & 0.300 & 38.935 & 0.649 & 0.217 & 43 \\
\hline 100 & 32.7025 & 2 & 6.633 & 0.302 & 39.131 & 0.652 & 0.850 & 49 \\
\hline 100 & 32.7025 & 2 & 6.650 & 0.301 & 39.033 & 0.651 & 0.500 & 56 \\
\hline 100 & 32.7025 & 2 & 6.383 & 0.313 & 40.663 & 0.678 & 0.883 & 62 \\
\hline 100 & 32.7025 & 2 & 6.583 & 0.304 & 39.428 & 0.657 & 0.467 & 69 \\
\hline
\end{tabular}


Appendix E: Influent Nitrate Testing Results

\begin{tabular}{|c|c|c|c|c|c|c|c|}
\hline Column ID & Sample Number & Concentartion Nitrate $(\mathrm{mg} / \mathrm{L})$ & Concentation $2(\mathrm{mg} / \mathrm{L})$ & Average Concentration (mg/L) & Standard Deviation & Percentage Removal compared to Inflent & Pore Volume \\
\hline Influent & NA & 1.92 & 1.81 & 1.865 & 0.038890873 & NA & 13.11 \\
\hline Tap Water & NA & 0.303 & 0.351 & 0.327 & 0.016970563 & NA & 13.11 \\
\hline 50 & 1 & 0.756 & 0.714 & 0.735 & 0.014849242 & $60.59 \%$ & 13.11 \\
\hline 50 & 2 & 0.557 & 0.778 & 0.6675 & 0.078135299 & $64.21 \%$ & 13.11 \\
\hline 50 & 3 & 0.468 & 0.351 & 0.4095 & 0.041365747 & $78.04 \%$ & 13.11 \\
\hline 50 & 4 & 1.21 & 0.545 & 0.8775 & 0.235113005 & $52.95 \%$ & 13.11 \\
\hline 60 & 1 & 1.87 & 0.714 & 1.292 & 0.40870772 & $30.72 \%$ & 11.34 \\
\hline 60 & 2 & 1.61 & 1.33 & 1.47 & 0.098994949 & $21.18 \%$ & 11.34 \\
\hline 60 & 3 & 1.72 & 1.4 & 1.56 & 0.113137085 & $16.35 \%$ & 11.34 \\
\hline 60 & 4 & 1.3 & 0.982 & 1.141 & 0.112429978 & $38.82 \%$ & 11.34 \\
\hline 60 & 5 & 1.52 & 1.4 & 1.46 & 0.042426407 & $21.72 \%$ & 11.34 \\
\hline 60 & 6 & 2.11 & 1.45 & 1.78 & 0.233345238 & $4.56 \%$ & 11.34 \\
\hline 60 & 7 & 1 & 1.08 & 1.04 & 0.028284271 & $44.24 \%$ & 11.34 \\
\hline 65 & 1 & 1.14 & 0.556 & 0.848 & 0.20647518 & $54.53 \%$ & 11.31 \\
\hline 65 & 2 & 0.85 & 0.69 & 0.77 & 0.056568542 & $58.71 \%$ & 11.31 \\
\hline 65 & 3 & 0.716 & 0.755 & 0.7355 & 0.013788582 & $60.56 \%$ & 11.31 \\
\hline 65 & 4 & 0.951 & 0.813 & 0.882 & 0.048790368 & $52.71 \%$ & 11.31 \\
\hline 65 & 5 & 1.44 & 1.4 & 1.42 & 0.014142136 & $23.86 \%$ & 11.31 \\
\hline 65 & 6 & 1.72 & 1.71 & 1.715 & 0.003535534 & $8.04 \%$ & 11.31 \\
\hline 70 & 1 & 0.848 & 0.716 & 0.782 & 0.046669048 & $58.07 \%$ & 11.62 \\
\hline 70 & 2 & 1.71 & 1.33 & 1.52 & 0.134350288 & $18.50 \%$ & 11.62 \\
\hline 70 & 3 & 2.89 & 1.52 & 2.205 & 0.484368145 & $-18.23 \%$ & 11.62 \\
\hline 70 & 4 & 1.98 & 1.59 & 1.785 & 0.137885822 & $4.29 \%$ & 11.62 \\
\hline 70 & 5 & 1.9 & 1.7 & 1.8 & 0.070710678 & $3.49 \%$ & 11.62 \\
\hline 70 & 6 & 1.96 & 1.7 & 1.83 & 0.091923882 & $1.88 \%$ & 11.62 \\
\hline 70 & 7 & 1.63 & 1.75 & 1.69 & 0.042426407 & $9.38 \%$ & 11.62 \\
\hline 70 & 8 & 1.71 & 1.68 & 1.695 & 0.010606602 & $9.12 \%$ & 11.62 \\
\hline 80 & 1 & 1.53 & 1.49 & 1.51 & 0.014142136 & $19.03 \%$ & 11.25 \\
\hline 80 & 2 & 2.04 & 1.8 & 1.92 & 0.084852814 & $-2.95 \%$ & 11.25 \\
\hline 80 & 3 & 2.17 & 2.01 & 2.09 & 0.056568542 & $-12.06 \%$ & 11.25 \\
\hline 80 & 4 & 2.02 & 2.06 & 2.04 & 0.014142136 & $-9.38 \%$ & 11.25 \\
\hline 80 & 5 & 2.31 & 2.04 & 2.175 & 0.095459415 & $-16.62 \%$ & 11.25 \\
\hline 80 & 6 & 2.04 & 2.04 & 2.04 & 0 & $-9.38 \%$ & 11.25 \\
\hline 80 & 7 & 0.804 & 0.944 & 0.874 & 0.049497475 & & 11.25 \\
\hline 100 & 1 & 1.38 & 1.4 & 1.39 & 0.007071068 & $25.47 \%$ & 10.67 \\
\hline 100 & 2 & 1.63 & 1.55 & 1.59 & 0.028284271 & $14.75 \%$ & 10.67 \\
\hline 100 & 3 & 1.83 & 1.62 & 1.725 & 0.074246212 & $7.51 \%$ & 10.67 \\
\hline 100 & 4 & 1.76 & 1.72 & 1.74 & 0.014142136 & $6.70 \%$ & 10.67 \\
\hline 100 & 5 & 1.94 & 1.69 & 1.815 & 0.088388348 & $2.68 \%$ & 10.67 \\
\hline 100 & 6 & 1.77 & 1.78 & 1.775 & 0.003535534 & $4.83 \%$ & 10.67 \\
\hline 100 & 7 & 1.6 & 1.78 & 1.69 & 0.06363961 & $9.38 \%$ & 10.67 \\
\hline
\end{tabular}


Appendix F: Total Suspended Solids Results For Clean Bed and Nitrate Testing

This Page is intentionally left blank 
Total Suspended Solids Worksheet

\begin{tabular}{|c|c|c|c|c|c|c|c|}
\hline $\begin{array}{c}\text { Column ID (\% Sand of } \\
\text { Column) }\end{array}$ & Tin ID & Mass of Tin (g) & $\begin{array}{c}\text { Mass of Clean Filter } \\
+ \text { Tin (g) }\end{array}$ & $\begin{array}{c}\text { Volume of Stormwater } \\
\text { Permeate }(\mathrm{mL})\end{array}$ & $\begin{array}{c}\text { Mass of Filter }+ \text { Tin } \\
\text { After Drying (g) }\end{array}$ & $\begin{array}{c}\text { Concentration of TSS in } \\
\text { Permeate }(\mathrm{mg} / \mathrm{L})\end{array}$ & $\begin{array}{c}\text { Pore Volume } \\
\text { Number }\end{array}$ \\
\hline 60 & 21 & - & 1.0502 & 150 & 1.0737 & 156.67 & 1 \\
\hline 60 & 15 & - & 1.0463 & 150 & 1.0749 & 190.47 & 1 \\
\hline 60 & 30 & - & 1.0453 & 150 & 1.0689 & 157.33 & 1 \\
\hline 80 & 7 & - & 1.0588 & 100 & 1.1299 & 711.00 & 1 \\
\hline 80 & 10 & - & 1.0633 & 100 & 1.1264 & 631.00 & 1 \\
\hline 80 & 64 & - & 1.0481 & 100 & 1.1260 & 779.00 & 1 \\
\hline 100 & 67 & - & 1.0497 & 150 & 1.0524 & 18.00 & 1 \\
\hline 100 & 50 & - & 1.0546 & 150 & 1.0564 & 12.00 & 1 \\
\hline 100 & 49 & - & 1.0526 & 150 & 1.0548 & 14.67 & 1 \\
\hline 70 & 6 & - & 1.0492 & 100 & 1.0850 & 358.00 & 3 \\
\hline 70 & 48 & - & 1.0544 & 100 & 1.0933 & 389.00 & 3 \\
\hline 70 & 43 & - & 1.0507 & 100 & 1.0930 & 423.00 & 3 \\
\hline 65 & 10 & - & 1.0453 & 150 & 1.0635 & 121.33 & 1 \\
\hline 65 & 38 & - & 1.0521 & 150 & 1.0715 & 129.33 & 1 \\
\hline 65 & 34 & - & 1.037 & 150 & 1.0581 & 140.67 & 1 \\
\hline 100 & 59 & - & 1.0541 & 150 & 1.0742 & 134.00 & 2 \\
\hline 100 & 42 & - & 1.0459 & 150 & 1.0652 & 128.67 & 2 \\
\hline 100 & 107 & - & 1.0461 & 150 & 1.0643 & 121.33 & 2 \\
\hline 100 & 3 & - & 1.0812 & 150 & 1.2233 & 947.33 & 1 \\
\hline 100 & 40 & - & 1.065 & 150 & 1.2248 & 1065.33 & 1 \\
\hline 100 & 107 & - & 1.0446 & 150 & 1.1942 & 997.33 & 1 \\
\hline 50 & 89 & - & 1.0514 & 100 & 1.2001 & 1487.00 & 1 \\
\hline 50 & 22 & - & 1.0453 & 100 & 1.2084 & 1631.00 & 1 \\
\hline 50 & 15 & - & 1.0578 & 100 & 1.2005 & 1427.00 & 1 \\
\hline 60 & 25 & - & 1.0452 & 150 & 1.0619 & 111.33 & 2 \\
\hline 60 & 42 & - & 1.0469 & 150 & 1.0586 & 78.00 & 2 \\
\hline 60 & 22 & - & 1.0472 & 150 & 1.0616 & 96.00 & 2 \\
\hline 100 & 15 & - & 1.0474 & 150 & 1.048 & 4.00 & 5 \\
\hline 100 & 10 & - & 1.0483 & 150 & 1.0485 & 1.33 & 5 \\
\hline 100 & 50 & - & 1.0541 & 150 & 1.0551 & 6.67 & 5 \\
\hline 80 & 59 & - & 1.053 & 150 & 1.0704 & 116.00 & 2 \\
\hline 80 & 39 & - & 1.0515 & 150 & 1.0692 & 118.00 & 2 \\
\hline 80 & 30 & - & 1.046 & 150 & 1.0636 & 117.33 & 2 \\
\hline 70 & 89 & - & 1.0504 & 150 & 1.1012 & 338.67 & 2 \\
\hline 70 & 111 & - & 1.0454 & 150 & 1.0908 & 302.67 & 2 \\
\hline 70 & 40 & - & 1.0522 & 150 & 1.103 & 338.67 & 2 \\
\hline
\end{tabular}




\begin{tabular}{|c|c|c|c|c|c|c|c|}
\hline $\begin{array}{c}\text { Column ID (\% Sand of } \\
\text { Column) }\end{array}$ & Tin ID & Mass of Tin (g) & $\begin{array}{c}\text { Mass of Clean Filter } \\
+ \text { Tin (g) }\end{array}$ & $\begin{array}{c}\text { Volume of Stormwater } \\
\text { Permeate }(\mathrm{mL})\end{array}$ & $\begin{array}{c}\text { Mass of Filter + Tin } \\
\text { After Drying (g) }\end{array}$ & $\begin{array}{l}\text { Concentration of TSS in } \\
\text { Permeate }(\mathrm{mg} / \mathrm{L})\end{array}$ & $\begin{array}{l}\text { Pore Volume } \\
\text { Number }\end{array}$ \\
\hline 70 & 1 & - & 1.0408 & 100 & 1.0655 & 247.00 & 3 \\
\hline 70 & 16 & - & 1.0462 & 100 & 1.0713 & 251.00 & 3 \\
\hline 70 & 100 & - & 1.047 & 100 & 1.0711 & 241.00 & 3 \\
\hline 100 & 53 & - & 1.0377 & 150 & 1.0389 & 8.00 & 4 \\
\hline 100 & 161 & - & 1.0486 & 150 & 1.0504 & 12.00 & 4 \\
\hline 100 & 56 & - & 1.0429 & 150 & 1.0438 & 6.00 & 4 \\
\hline 100 & 56 & - & 1.0272 & 150 & 1.0208 & -42.67 & 8 \\
\hline 100 & 25 & - & 1.0314 & 150 & 1.0314 & 0.00 & 8 \\
\hline 100 & 10 & - & 1.0306 & 150 & 1.0311 & 3.33 & 8 \\
\hline 65 & 50 & - & 1.054 & 100 & 1.0878 & 338.00 & 4 \\
\hline 65 & 59 & - & 1.0557 & 110 & 1.0793 & 214.55 & 4 \\
\hline 65 & 111 & - & 1.0465 & 100 & 1.0882 & 417.00 & 4 \\
\hline 70 & 3 & - & 1.0411 & 50 & 1.0523 & 224.00 & 3 \\
\hline 70 & 40 & - & 1.0356 & 50 & 1.0469 & 226.00 & 3 \\
\hline 70 & 49 & - & 1.0465 & 50 & 1.0569 & 208.00 & 3 \\
\hline 80 & 38 & - & 1.036 & 50 & 1.0443 & 166.00 & 3 \\
\hline 80 & 40 & - & 1.0392 & 50 & 1.0464 & 144.00 & 3 \\
\hline 80 & 89 & - & 1.0354 & 50 & 1.0426 & 144.00 & 3 \\
\hline 100 & 1 & - & 1.0237 & 50 & 1.0232 & -10 & 6 \\
\hline 100 & 15 & - & 1.031 & 50 & 1.0306 & -8 & 6 \\
\hline 100 & 16 & - & 1.0284 & 50 & 1.0281 & -6 & 6 \\
\hline 60 & 22 & - & 1.0308 & 50 & 1.0383 & 150 & 3 \\
\hline 60 & 30 & - & 1.0299 & 50 & 1.0372 & 146 & 3 \\
\hline 60 & 42 & - & 1.0311 & 50 & 1.0392 & 162 & 3 \\
\hline 65 & 53 & - & 1.023 & 50 & 1.0422 & 384.00 & 2 \\
\hline 65 & 100 & - & 1.0302 & 50 & 1.0511 & 418.00 & 2 \\
\hline 65 & 161 & - & 1.0308 & 50 & 1.0504 & 392.00 & 2 \\
\hline 50 & 21 & - & 1.0349 & 50 & 1.0696 & 694.00 & 2 \\
\hline 50 & 43 & - & 1.0344 & 50 & 1.0696 & 704.00 & 2 \\
\hline 50 & 67 & - & 1.0323 & 50 & 1.0706 & 766.00 & 2 \\
\hline 60 & 2 & - & 1.0266 & 50 & 1.0431 & 330.00 & 4 \\
\hline 60 & 45 & - & 1.0311 & 50 & 1.0483 & 344.00 & 4 \\
\hline 60 & 64 & - & 1.0304 & 50 & 1.0468 & 328.00 & 4 \\
\hline 80 & 20 & - & 1.0316 & 50 & 1.037 & 108.00 & 4 \\
\hline 80 & 27 & - & 1.0457 & 50 & 1.0505 & 96.00 & 4 \\
\hline 80 & 42 & - & 1.0333 & 50 & 1.0383 & 100.00 & 4 \\
\hline 70 & 4 & - & 1.0279 & 50 & 1.0449 & 340.00 & 5 \\
\hline 70 & 6 & - & 1.0313 & 50 & 1.0471 & 316.00 & 5 \\
\hline
\end{tabular}




\begin{tabular}{|c|c|c|c|c|c|c|c|}
\hline $\begin{array}{c}\text { Column ID (\% Sand of } \\
\text { Column) }\end{array}$ & Tin ID & Mass of Tin $(\mathrm{g})$ & $\begin{array}{c}\text { Mass of Clean Filter } \\
+ \text { Tin (g) }\end{array}$ & $\begin{array}{c}\text { Volume of Stormwater } \\
\text { Permeate }(\mathrm{mL})\end{array}$ & \begin{tabular}{|c|} 
Mass of Filter + Tin \\
After Drying $(\mathrm{g})$
\end{tabular} & $\begin{array}{l}\text { Concentration of TSS in } \\
\text { Permeate }(\mathrm{mg} / \mathrm{L})\end{array}$ & $\begin{array}{c}\text { Pore Volume } \\
\text { Number }\end{array}$ \\
\hline 70 & 107 & - & 1.0263 & 50 & 1.0423 & 320.00 & 5 \\
\hline 100 & 15 & - & 1.0424 & 50 & 1.0422 & 0.00 & 7 \\
\hline 100 & 34 & - & 1.02 & 50 & 1.0201 & 2.00 & 7 \\
\hline 100 & 48 & - & 1.0387 & 50 & 1.0389 & 4.00 & 7 \\
\hline 50 & 10 & - & 1.0468 & 50 & 1.0574 & 212.00 & 4 \\
\hline 50 & 59 & - & 1.0543 & 50 & 1.064 & 194.00 & 4 \\
\hline 50 & - & - & - & - & - & - & 4 \\
\hline 60 & 40 & - & 1.0539 & 50 & 1.0623 & 168.00 & 5 \\
\hline 60 & 49 & - & 1.0527 & 50 & 1.0617 & 180.00 & 5 \\
\hline 60 & - & - & - & - & - & - & 5 \\
\hline 65 & 3 & - & 1.0585 & 50 & 1.069 & 210.00 & 5 \\
\hline 65 & 89 & - & 1.0518 & 50 & 1.0633 & 230.00 & 5 \\
\hline 65 & - & - & - & - & - & - & 5 \\
\hline 60 & 6 & - & 1.0493 & 50 & 1.0533 & 80.00 & 6 \\
\hline 60 & 100 & - & 1.0467 & 50 & 1.0505 & 76.00 & 6 \\
\hline 60 & - & - & - & - & - & - & 6 \\
\hline 70 & 43 & - & 1.0505 & 50 & 1.063 & 250.00 & 7 \\
\hline 70 & 45 & - & 1.0489 & 50 & 1.0615 & 252.00 & 7 \\
\hline 70 & - & - & & - & - & - & 7 \\
\hline 70 & 53 & - & 1.0383 & 50 & 1.0459 & 152.00 & 8 \\
\hline 70 & 64 & - & 1.046 & 50 & 1.05 & 80.00 & 8 \\
\hline 70 & - & - & - & - & - & - & 8 \\
\hline 80 & 1 & - & 1.0405 & 50 & 1.0481 & 152.00 & 5 \\
\hline 80 & 25 & - & 1.0462 & 50 & 1.0507 & 90.00 & 5 \\
\hline 80 & - & - & - & - & - & - & 5 \\
\hline 80 & 50 & - & 1.0545 & 50 & 1.0588 & 86.00 & 6 \\
\hline 80 & 56 & - & 1.0448 & 50 & 1.049 & 84.00 & 6 \\
\hline 80 & - & - & - & - & - & & 6 \\
\hline $100 \mathrm{~N}$ & 10 & - & 1.0308 & 50 & 1.0297 & 0.00 & 9 \\
\hline $100 \mathrm{~N}$ & 59 & - & 1.0337 & 50 & 1.0335 & 0.00 & 10 \\
\hline $100 \mathrm{~N}$ & 64 & - & 1.0273 & 50 & 1.0268 & 0.00 & 11 \\
\hline $100 \mathrm{~N}$ & 40 & - & 1.035 & 50 & 1.0347 & 0.00 & 12 \\
\hline $100 \mathrm{~N}$ & 67 & - & 1.0298 & 50 & 1.0293 & 0.00 & 13 \\
\hline $100 \mathrm{~N}$ & 49 & - & 1.0331 & 50 & 1.0327 & 0.00 & 14 \\
\hline $100 \mathrm{~N}$ & 48 & - & 1.0349 & 50 & 1.0345 & 0.00 & 15 \\
\hline $100 \mathrm{~N}$ & 107 & - & 1.0231 & 50 & 1.0241 & 20.00 & 16 \\
\hline- & & - & & & & & \\
\hline $80 \mathrm{~N}$ & & - & 1.0319 & 50 & 1.0412 & 186.00 & 7 \\
\hline
\end{tabular}




\begin{tabular}{|c|c|c|c|c|c|c|c|}
\hline $\begin{array}{c}\text { Column ID (\% Sand of } \\
\text { Column) }\end{array}$ & Tin ID & Mass of Tin $(\mathrm{g})$ & $\begin{array}{c}\text { Mass of Clean Filter } \\
+\operatorname{Tin}(\mathrm{g})\end{array}$ & $\begin{array}{c}\text { Volume of Stormwater } \\
\text { Permeate }(\mathrm{mL})\end{array}$ & $\begin{array}{c}\text { Mass of Filter }+ \text { Tin } \\
\text { After Drying (g) } \\
\end{array}$ & $\begin{array}{c}\text { Concentration of TSS in } \\
\text { Permeate (mg/L) }\end{array}$ & $\begin{array}{l}\text { Pore Volume } \\
\text { Number }\end{array}$ \\
\hline $80 \mathrm{~N}$ & & - & 1.0249 & 50 & 1.0297 & 96.00 & 8 \\
\hline $80 N$ & & - & 1.0269 & 50 & 1.0307 & 76.00 & 9 \\
\hline $80 N$ & & - & 1.0259 & 50 & 1.0301 & 84.00 & 10 \\
\hline $80 N$ & & - & 1.0317 & 50 & 1.0351 & 68.00 & 11 \\
\hline $80 N$ & & - & 1.0329 & 50 & 1.0361 & 64.00 & 12 \\
\hline $70 N$ & & - & 1.0231 & 50 & 1.0361 & 260.00 & 8 \\
\hline $70 N$ & & - & 1.0277 & 50 & 1.0328 & 102.00 & 9 \\
\hline $70 N$ & & - & 1.0379 & 50 & 1.0429 & 100.00 & 10 \\
\hline $70 \mathrm{~N}$ & & - & 1.0323 & 50 & 1.0365 & 84.00 & 11 \\
\hline $70 N$ & & - & 1.0192 & 50 & 1.0234 & 84.00 & 12 \\
\hline $70 \mathrm{~N}$ & & - & 1.0214 & 50 & 1.025 & 72.00 & 13 \\
\hline $70 N$ & & - & 1.0177 & 50 & 1.0212 & 70.00 & 14 \\
\hline $70 \mathrm{~N}$ & & - & 1.0339 & 50 & 1.0369 & 60.00 & 15 \\
\hline- & & - & & & & & \\
\hline $60 N$ & 53 & - & 1.0278 & 20 & 1.0283 & 25.00 & 7 \\
\hline $60 N$ & 2 & - & 1.024 & 27 & 1.0338 & 362.96 & 7 \\
\hline- & & - & & & & & \\
\hline $60 N$ & 161 & - & 1.0307 & 25 & 1.0331 & 96.00 & 8 \\
\hline $60 N$ & 20 & - & 1.0269 & 25 & 1.0334 & 260.00 & 8 \\
\hline- & & - & & & & & \\
\hline $60 N$ & 42 & - & 1.0264 & 25 & 1.0325 & 244.00 & 9 \\
\hline $60 N$ & 25 & - & 1.0316 & 25 & 1.0271 & -180.00 & 9 \\
\hline - & & - & & & & & \\
\hline $60 N$ & 100 & - & 1.0264 & 35 & 1.0320 & 160.00 & 10 \\
\hline $60 N$ & 89 & - & 1.0316 & 17 & 1.0372 & 329.41 & 10 \\
\hline- & & - & & & & & \\
\hline $60 N$ & 4 & - & 1.0246 & 30 & 1.0280 & 113.33 & 11 \\
\hline $60 N$ & 10 & - & 1.0321 & 22 & 1.0338 & 77.27 & 11 \\
\hline- & & - & & & & & \\
\hline $60 N$ & 45 & - & 1.0276 & 30 & 1.0303 & 90.00 & 12 \\
\hline $60 \mathrm{~N}$ & 50 & - & 1.0367 & 23 & 1.0386 & 82.61 & 12 \\
\hline- & & - & & & & & \\
\hline $60 N$ & 1 & - & 1.0209 & 26 & 1.0224 & 57.69 & 13 \\
\hline \multirow[t]{2}{*}{$60 N$} & 56 & - & 1.0248 & 24 & 1.0262 & 58.33 & 13 \\
\hline & & - & & & & & \\
\hline $50 \mathrm{~N}$ & 40 & - & 1.0334 & 25 & 1.0401 & 268.00 & 5 \\
\hline \multirow[t]{2}{*}{$50 \mathrm{~N}$} & 6 & - & 1.0331 & 25 & 1.0355 & 96.00 & 5 \\
\hline & & - & & & & & \\
\hline
\end{tabular}




\begin{tabular}{|c|c|c|c|c|c|c|c|}
\hline $\begin{array}{c}\text { Column ID (\% Sand of } \\
\text { Column) }\end{array}$ & Tin ID & Mass of Tin $(\mathrm{g})$ & $\begin{array}{c}\text { Mass of Clean Filter } \\
+ \text { Tin (g) }\end{array}$ & $\begin{array}{c}\text { Volume of Stormwater } \\
\text { Permeate }(\mathrm{mL})\end{array}$ & $\begin{array}{c}\text { Mass of Filter }+ \text { Tin } \\
\text { After Drying }(\mathrm{g})\end{array}$ & $\begin{array}{c}\text { Concentration of TSS in } \\
\text { Permeate }(\mathrm{mg} / \mathrm{L})\end{array}$ & $\begin{array}{l}\text { Pore Volume } \\
\text { Number }\end{array}$ \\
\hline $50 \mathrm{~N}$ & 7 & - & 1.038 & 25 & 1.0403 & 92.00 & 6 \\
\hline \multirow[t]{2}{*}{$50 N$} & 21 & - & 1.0316 & 25 & 1.0338 & 88.00 & 6 \\
\hline & & - & & & & & \\
\hline $50 \mathrm{~N}$ & 5 & - & 1.0266 & 24 & 1.0288 & 91.67 & 7 \\
\hline \multirow{2}{*}{$50 N$} & 29 & - & 1.018 & 26 & 1.0202 & 84.62 & 7 \\
\hline & & - & & & & & \\
\hline $65 N$ & 3 & - & 1.0402 & 25 & 1.0451 & 196.00 & 5 \\
\hline \multirow[t]{2}{*}{$65 N$} & 43 & - & 1.0318 & 25 & 1.0373 & 220.00 & 5 \\
\hline & & - & & & & & \\
\hline $65 N$ & 162 & - & 1.0204 & 30 & 1.0227 & 76.67 & 6 \\
\hline \multirow[t]{2}{*}{$65 N$} & 27 & - & 1.0292 & 23 & 1.0313 & 91.30 & 6 \\
\hline & & - & & & & & \\
\hline $65 N$ & 26 & - & 1.0307 & 25 & 1.0338 & 124.00 & 7 \\
\hline \multirow[t]{2}{*}{$65 N$} & 133 & - & 1.0251 & 25 & 1.0281 & 120.00 & 7 \\
\hline & & - & & & & & \\
\hline $65 N$ & 2 & - & 1.0296 & 25 & 1.0327 & 124.00 & 8 \\
\hline \multirow[t]{2}{*}{$65 N$} & 38 & - & 1.0328 & 25 & 1.0358 & 120.00 & 8 \\
\hline & & - & & & & & \\
\hline
\end{tabular}

